\title{
Boundary Spanning in the Entrepreneurial Firm: \\ Effects on Innovation and Firm Performance
}

\section{BY}

LAUREL F. OFSTEIN

B.A., Kalamazoo College, 1998

M.B.A., DePaul University, 2005

\begin{abstract}
THESIS
Submitted as partial fulfillment of the requirements

for the degree of Doctor of Philosophy in Business Administration in the Graduate College of the

University of Illinois at Chicago, 2013
\end{abstract}

\author{
Chicago, Illinois
}

Defense Committee:

Rod Shrader, Chair and Advisor

Joseph Cherian

Abagail McWilliams

Maija Renko

Lisa Gundry, DePaul University 


\section{ACKNOWLEDGEMENTS}

I would like to first thank my husband, Charlie, for his support throughout my gradate studies. Without his love, encouragement, and perhaps most importantly, his example of what it means to be diligent, hard-working, and devoted to achieving the career to which one aspires, I would not have been able to reach this point. I also would like to thank our two wonderful children, Micah and Lucas, for their patience and love. To my parents, Walt and Marty Fitzhugh, I thank you for instilling in me a love of learning, and the feeling that with hard work and a goal I really can achieve it all.

I would like to thank Rod Shrader, my dissertation chair, for pushing me to always work harder, aim higher, and look deeper, in terms of my research. He has helped me to grow as a scholar and as a person throughout this process. I look forward to conducting quality research with him in the years to come.

I would like to thank my dissertation committee members, Joseph Cherian, Lisa Gundry, Abagail McWilliams, and Maija Renko. Rod and the committee have supported me not only through the dissertation process, but also throughout my doctoral studies. I have learned a tremendous amount from each of them. I would like to give special mention to Lisa Gundry, who first hired me as her Graduate Assistant many years ago and started me on this journey by sharing her love of academia with me, and to Maija Renko, who took the time to train me in the practical aspects of doing research and has always held me to a high standard, which has made me a stronger researcher.

Lastly, thank you to Gerry Hills for being my first mentor at UIC, and for continuing to encourage me despite his absence, and Al Page, who pushed me to open myself beyond entrepreneurship research to a broader view of new product development and innovation. 


\section{TABLE OF CONTENTS}

CHAPTER

$\underline{\text { PAGE }}$

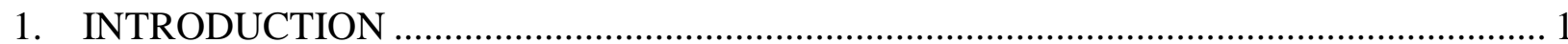

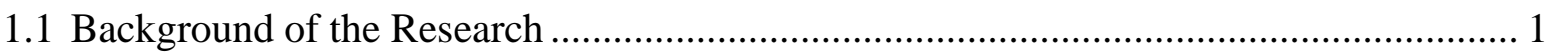

1.2 Research Gap and Questions ....................................................................................... 4

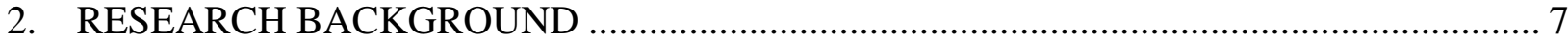

2.1 Boundary Spanning Theory ……………………………......................................... 7

2.2 Boundary Spanning and a Theory of the Boundary-Spanning Marketing Organization 11

2.3 Boundary Spanning in Entrepreneurial Firms ........................................................... 14

2.4 Organizational Learning Theory .................................................................................... 14

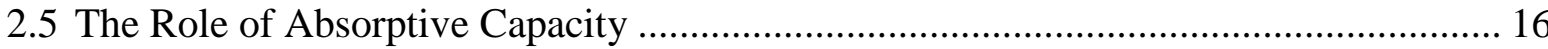

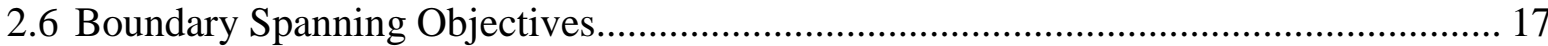

2.7 Breadth and Depth of Boundary Spanning .................................................................... 19

3. CONCEPTUAL FRAMEWORK AND HYPOTHESIS DEVELOPMENT ........................... 22

3.1 Boundary Spanning and Firm Innovativeness ……………………………………..... 22

3.2 Boundary Spanning, Absorptive Capacity, and Firm Innovativeness ............................. 26

3.3 Firm Innovativeness and Firm Performance.................................................................. 27

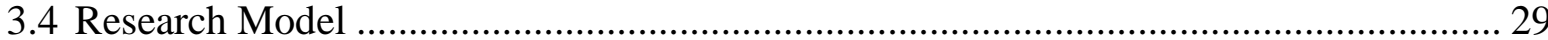

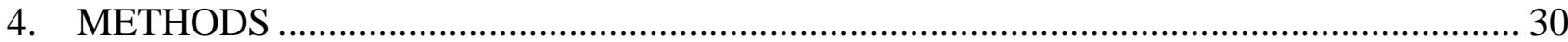

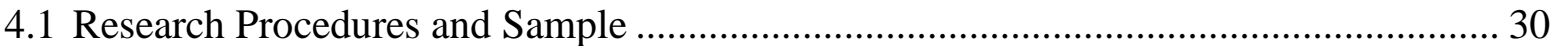

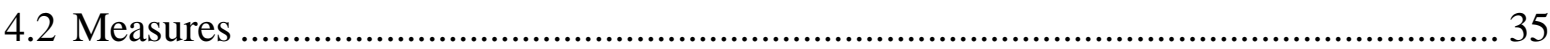

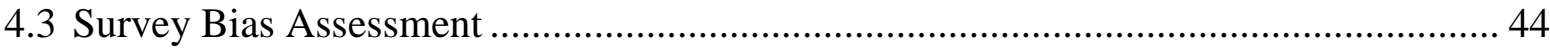

4.4 Common Method Bias ................................................................................................ 45

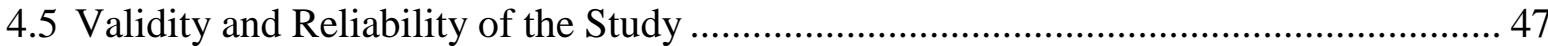

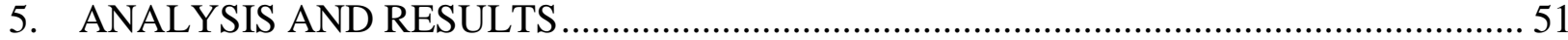

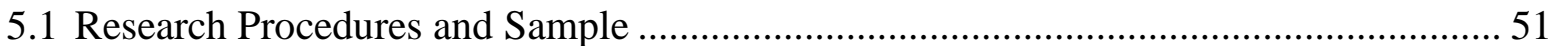

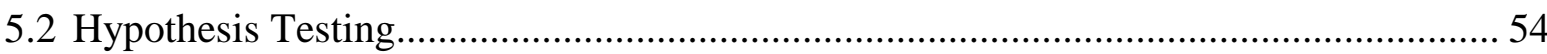

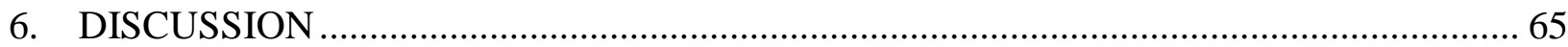

6.1 Limitations and Future Research ……………………................................................. 70

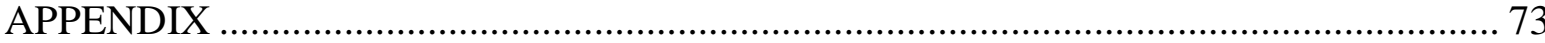

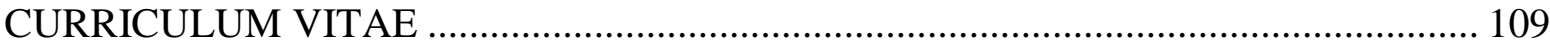

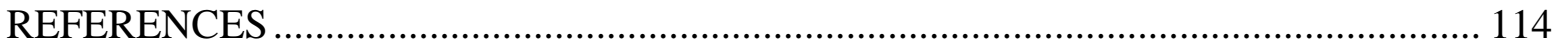




\section{LIST OF TABLES}

TABLE I: BOUNDARY SPANNING THEORY SUMMARY ……………………………...... 10

TABLE II: MOR THEORY IN ENTREPRENEURIAL FIRMS.................................................... 13

TABLE III. SAMPLING FRAMES AND RESPONSE RATES …………………….................. 33

TABLE IV: SUMMARY OF JOB TITLES OF SURVEY PARTICIPANTS ................................ 34

TABLE V: RELIABILITY ANALYSIS OF ABSORPTIVE CAPACITY SCALE...................... 42

TABLE VI: CORRELATIONS BETEEN BOUNDARY SPANNING BREADTH AND

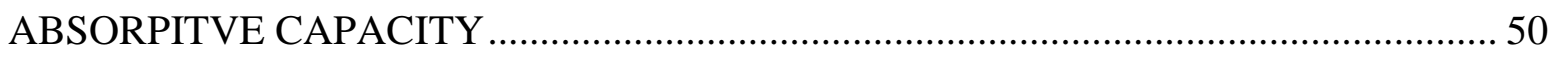

TABLE VII: CORRELATIONS BETEEN BOUNDARY SPANNING DEPTH AND

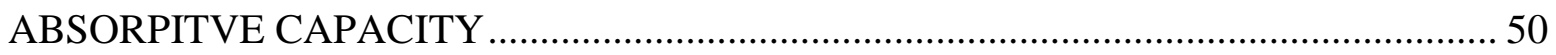

TABLE VIII: VARIABLE DESCRIPTIVE STATISTICS.......................................................... 51

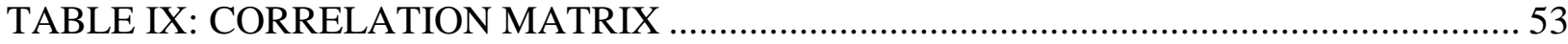

TABLE X: EFFECTS OF BOUNDARY SPANNING BREADTH ON FIRM

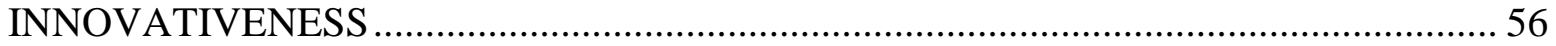

TABLE XI: EFFECTS OF BOUNDARY SPANNING DEPTH ON FIRM INNOVATIVENESS

TABLE XII: INTERACTION EFFECT OF ABSORPTIVE CAPACITY BETWEEN BREADTH AND DEPTH OF STRATEGIC BOUNDARY SPANNING AND FIRM INNOVATIVENESS

TABLE XIII: MEDIATED REGRESSION ANALYSIS BETWEEN BOUNDARY SPANNING

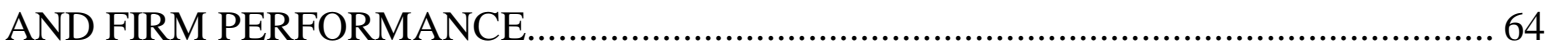




\section{LIST OF FIGURES}

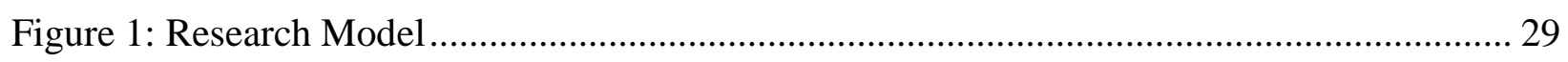




\section{LIST OF ABBREVIATIONS}

ACAP Absorptive Capacity

CEO Chief Executive Officer

Cf. Compare

CIS Community Innovation Survey

M \& A Mergers and Acquisitions

MOR Boundary-Spanning Marketing Organization

R \& D Research and Development

S.D. Standard Deviation

SME Small or Medium-sized Enterprise

SPRU Science and Technology Policy Research

U.K. United Kingdom

VIF Variance Inflation Factor 


\section{SUMMARY}

This study examines the role of boundary spanning breadth and depth in driving innovation and performance within entrepreneurial firms. Three boundary spanning objectives are introduced to determine how the purpose with which boundary spanning is pursued may have a unique effect on firm innovativeness. Absorptive capacity is proposed as a moderating variable between boundary spanning breadth and depth and firm innovativeness. Using multiple regression analysis with a sample of entrepreneurial firms, this study demonstrates that pursuing boundary spanning with a strategic objective is the most important driver of firm innovativeness and performance. 


\section{INTRODUCTION}

A condition of organization survival is effective interaction with the external environment of the organization.

-- J. Stacy Adams (1976, p.1175)

\subsection{Background of the Research}

A firm's external environment is home to a diverse set of knowledge sources that could potentially lead to commercializable innovations (Rothaermel and Alexandre, 2009). Innovations have been found to frequently, and increasingly, originate from outside of organizations (Cassiman and Veugelers, 2002; Kostopoulos, Papalexandris, Papachroni, and Ioannou, 2011; Morgan and Berthon, 2008) thus, successfully integrating information from sources external to the firm should be a priority. However, entrepreneurial firms, which seize, evaluate, and exploit opportunities (Shane and Venkataraman, 2000), tend to suffer from scarcity of resources - not only due to constraints on financial and physical resources (Kirchhoff, 1994), but also due to the entrepreneur's limited time and attention span (Garud and Ven de Ven, 1992; Ravasi and Turati, 2005). Determining which external information to pursue, and then to integrate into the innovation process, can be especially challenging.

Boundary spanning is the concept that firms have a boundary that is represented either by the interface between the firm and the market environment, or by the interaction between the departments within a firm (Lysonski, 1985; Sturdy and Wright, 2011). This interface between the external market environment and the firm itself has been historically linked to innovation (Aldrich and Herker, 1977; Tushman, 1977; Utterback, 1971). Innovation, or the innovation 
process, is broadly defined in this research, as “developing a new product or service idea, a new process technology, a new business model, a new organizational form, and so on” (Snow, 2007, p. 101). The means of innovating are vast and varied, and entrepreneurial firms, meaning firms that engage in product, service, or market innovation, and undertake somewhat risky ventures, are often first to come up with proactive innovations (Miller, 1983). Entrepreneurial firms also require frequent decisions about which opportunities should be pursued, and which are worth exploring further (Ravasi and Turati, 2005).

Extant research has yet to fully explore the relationship between a firm's innovation search strategy and the resulting innovativeness of the firm’s products (Laursen and Salter, 2006). In their work exploring how external knowledge flows affect innovation and financial performance, Kostoupoulous, et al. (2011) call for further research on antecedent conditions of absorptive capacity, or the way in which firms recognize external knowledge, assimilate it, and apply it to commercial ends (Jansen, Van Den Bosch, and Volberda, 2005). Some of the variables they, and others, highlight as needing further examination include knowledge inflows, the type of knowledge that each external partner contributes, and outcomes, such as innovation and firm performance (Kostopoulos et al., 2011; Lane, Koka, and Pathak, 2006). This research addresses these topics by looking at how different information sources, and the type of interactions pursued with these information sources, affect absorptive capacity, and the outcomes of firm innovativeness and firm performance.

Gassmann, et al. (2010) call for future studies to develop typologies of innovation activities to identify some consistency toward the opening up of the innovation process. While prior research has organized activities focused on acquiring external knowledge into categories such as “market sources” and “institutional sources” (Laursen and Salter, 2006) and 
“professional sources” and “personal sources” (Cooper, Folta, and Woo, 1995), these forms of categorization do not capture the purpose for which the firm is seeking the external knowledge. The concept of external knowledge exploration has been researched under many names and with several overlapping constructs, including: external orientation (Laursen and Salter, 2006), information search (Cooper et al., 1995), and open innovation (Chesbrough, 2003; Chesbrough, 2006; Laursen and Salter, 2006). While many of these terms are related and connote some part of the search for innovative ideas beyond the firm itself, they are narrowly focused on the idea of information, or knowledge search, solely for the purpose of achieving future profits and commercial ends. While this research will also look at the outcomes of innovation and performance, the boundary spanning activities studied are broad and encompass not only interacting with universities or consultants, but also conducting Internet research or searching social media.

Boundary spanning represents a broad term, which encompasses the flow of information that may permeate a firm from the outside environment for a variety of purposes. As mentioned previously, boundary spanning can be examined either at the interface between the firm and the market environment, or by the interaction between the departments within a firm (Lysonski, 1985; Sturdy and Wright, 2011). This study will focus on the interface between the firm and its environment and examine how external information from beyond the firm's boundaries (meaning from individuals or organizations not employed by the firm) is sought out for the purpose of providing general information to the firm or improving the day-to-day operations of the firm, in addition to driving innovation and performance within the boundaries of the firm. Most employees involved in the innovation process are working at the firm boundary (the interface between the firm and the market) in an effort to identify, purchase, import, and/or 
legitimize new or outside ideas and practices (Sturdy and Wright, 2011). The definition of a boundary between the firm and the environment is important because "in the absence of distinguishable boundaries, there can be no organizations as we understand that term” (Scott, 1998, p. 182). Boundary spanning, in terms of individuals acting as exchange agents between the firm and its environment, is well established (Aldrich and Herker, 1977; Leifer and Delbecq, 1978; Tushman, 1977; Tushman and Scanlan, 1981), but boundary spanning activities, such as interacting with customers, suppliers, institutions of higher learning, etc., take on a unique dimension within the entrepreneurial firm. Entrepreneurs may possess a good knowledge of the market, the customers, and the technical requirements to compete; however, it is in the area of turning innovation ideas into reality which requires not only financial resources, but also skills and competencies from industrial and research partners, consultants, or other contributors from outside of the firm, with which they struggle (Birley, 1986; Dubini and Aldrich, 1991; Larson, 1991; Ravasi and Turati, 2005).

\subsection{Research Gap and Questions}

Extant research has called for a better understanding of how instrumental boundary spanning is in the innovation process (Kostopoulos et al., 2011; Lane et al., 2006; Lysonski,

1985). By engaging with a large number of different external information sources, or by relying heavily on one or more external information sources, entrepreneurial firms may collect a large number of innovative ideas, but not have the capacity to successfully commercialize them. Further, by expending limited resources on interactions with external information sources ("boundary spanning activities") the entrepreneurial firm may be unable to effectively integrate the learnings from these activities into its innovation process. The constraint of limited firm 
resources in entrepreneurial firms may lead to a point of diminishing returns for integrating information gathered through boundary spanning activities intended to drive innovative new products or services. Few studies have looked at the influence of external information on innovation in entrepreneurial firms (Brodzinski, Scherer, and Wiebe, 1990; Cooper et al., 1995), and yet they may benefit more from innovation than more mature organizations (Rosenbusch, Brinckmann, and Bausch, 2011).

While much external information is gained through engaging in boundary spanning, additional research is still needed to examine the type of information that each external partner contributes to firm innovativeness and performance (Kostopoulos et al., 2011). In this study, I use boundary spanning and organizational learning theory to examine how the pursuit of different boundary spanning objectives (the purpose that the boundary spanning is intended to accomplish), and how the extent to which entrepreneurial firms seek information externally, may ultimately affect firm innovativeness and firm performance.

Specifically, the research questions for this study are: how do an entrepreneurial firm's different boundary spanning objectives affect overall firm innovativeness and performance? For example, is the firm engaging in activities that are strategic, operational, or informational in nature? How do the depth and breadth of boundary spanning activity influence firm innovativeness and firm performance? Lastly, as entrepreneurial firms have limited resources and capacity to absorb the outcomes of these boundary spanning activities, how does the capacity of the entrepreneurial firm to absorb and commercialize learnings acquired through these activities affect firm innovativeness and firm performance?

This study will first present the concepts of breadth and depth of boundary spanning and introduce three objectives for pursuing these activities. The relationship between each of the 
boundary spanning objectives and entrepreneurial firm innovativeness is expected to be curvilinear - demonstrating that too little informational, operational, or strategic boundary spanning is insufficient for achieving firm innovativeness, and too much boundary spanning overtaxes the firm’s resources. Too little boundary spanning activity results in the entrepreneurial firm not having enough unique information to drive new product innovations. Equally, too much boundary spanning activity limits innovation because the entrepreneurial firm becomes overwhelmed with the influx of ideas and the resources it takes to evaluate them. Taking both arguments together, I propose there will be a middle-ground for boundary spanning which is optimal for entrepreneurial firm innovativeness.

Second, this study will examine how the breadth and depth of boundary spanning influences entrepreneurial firm innovativeness. For example, does boundary spanning that is strategic in nature require a greater number of unique activities to reach an ideal level of firm innovativeness than activities that are operational in nature? And lastly, I will explore how the entrepreneurial firm’s absorptive capacity - the ability of a firm to identify and value external knowledge (Cohen and Levinthal, 1990; Cohen and Levinthal, 1994) - affects the relationships between the various forms of boundary spanning and firm innovativeness. The effect of firm innovativeness on firm performance will also be assessed. 


\section{RESEARCH BACKGROUND}

\subsection{Boundary Spanning Theory}

All organizations are incomplete and must depend on exchanges with other systems, as well as being open to environmental influences, to survive (Scott, 1998). Boundary spanning theory originated over three decades ago in an effort to more clearly define the interactions between organizations and the environment (early works include: Adams, 1976; Aldrich and Herker, 1977; Leifer and Huber, 1977). More recent ways of doing business have complicated the ease with which we used to draw organizational boundaries. For example, research and development may be conducted in partnership with local universities, and marketing departments may engage more directly with lead users to develop and test new products (Scott, 1998). However, for purposes of this research, the organizational boundary is defined as between employees of the firm and the broad or market environment and the focus will be on how interactions at this boundary drive innovation and performance within the firm.

The most important input to the organizational process of innovation is new information from the environment (Alam, 2003). By linking the firm to elements in the external environment, boundary spanning activities facilitate the information flow between the environment and the firm (Aiken and Hage, 1968; Ancona, Bresman, and Kaeufer, 2002; Keller and Holland, 1975; Leifer and Delbecq, 1978). De Bretani and Reid (2012) present the most recent application of boundary spanning, focusing on the interface between the boundary spanner (individual employee) and the environment, laying out several propositions for the factors affecting the flow of information, which may lead to discontinuous innovations. The individual (internal to the firm) - environment (external to the firm) relationship examined in de Bretani and Reid (2012) also draws on social network analysis (Scott, 1991; Wasserman and Faust, 
1994). The integration of social network analysis is fitting for the de Bretani and Reid study because they look broadly at the intersection of three realms: the information and data the boundary spanner interfaces with from sources in the environment, the people the boundary spanner interacts with both in the environment and inside the firm, and the boundary spanner's own personal characteristics (de Brentani and Reid, 2012). The intersection of these three views is consistent with boundary spanning theory, which looks at four factors that influence the behavior of the individual and/or the organization engaging in the boundary spanning (Adams, 1976; Callister and Wall Jr., 2001):

(1) the nature of the boundary spanner's relationship with his or her own firm,

(2) the boundary spanner - external organization interaction,

(3) the boundary spanner’s personal characteristics, and

(4) the relationship between the boundary spanner’s firm and the external organization. This research presents an extension of this theory by examining boundary spanning influences on firm innovativeness and performance in entrepreneurial organizations. The firm-level does not lend itself to social network analysis and thus, boundary spanning and organizational learning will be used as the theoretical foundation for this research.

Tushman (1977) explored special boundary roles in the innovation process as a way for the innovating organization to deal with cross-boundary communication. The necessity of these roles is based on research by Utterback (1971), who found that during the first phase of the innovation process, idea generation, information related to new ideas or approaches to technical or marketing problems is found most effectively outside of the innovating organization. While this research will not explore boundary roles at the individual level, Utterback (1971) and 
Tushman (1977) demonstrate the early link between boundary spanning and the innovation process.

Some examples of how entrepreneurial firms might engage in boundary spanning today would be a Research and Development (R\&D) department working with a university to combine a college's pharmaceutical expertise with the firm's biological knowledge to generate a new drug. Another example is nanotechnology, which builds on the convergence of technological and scientific fields. A scientifically-oriented firm may join a technology trade association in order to leverage the knowledge of its members in product development.

The following table (Table 1) provides an overview of key boundary spanning theory research and my own assertions of the implications of each for this research study: 


\section{TABLE I: BOUNDARY SPANNING THEORY SUMMARY}

\begin{tabular}{|c|c|c|c|}
\hline Article & $\begin{array}{c}\text { Contribution to boundary } \\
\text { spanning theory }\end{array}$ & Additional insights from the article & Link to present study \\
\hline $\begin{array}{l}\text { Lysonski, } \\
1985\end{array}$ & $\begin{array}{l}\text { Asserts that a product manager has a } \\
\text { given propensity to engage in } \\
\text { boundary spanning regardless of } \\
\text { environmental uncertainty. }\end{array}$ & $\begin{array}{l}\text { Individuals engaged in the innovation } \\
\text { process (in this case, product } \\
\text { development) need a network of } \\
\text { internal and external linkages } \\
\text { established through boundary spanning. }\end{array}$ & $\begin{array}{l}\text { Just as the product manager is a } \\
\text { central transmitter of information } \\
\text { about product development into the } \\
\text { firm, so is the entrepreneur central in } \\
\text { driving information about } \\
\text { innovation into the firm. }\end{array}$ \\
\hline $\begin{array}{l}\text { De Brentani } \\
\text { and Reid, } \\
2012\end{array}$ & $\begin{array}{l}\text { Presents several propositions with } \\
\text { key factors impacting individual } \\
\text { boundary spanners in bringing } \\
\text { information into the fuzzy front-end } \\
\text { of discontinuous innovations. }\end{array}$ & $\begin{array}{l}\text { Underscores importance of the } \\
\text { characteristics of the innovation, the } \\
\text { position of the boundary spanner in the } \\
\text { social network, and the boundary } \\
\text { spanner's ability to recognize patterns } \\
\text { in the environment. }\end{array}$ & $\begin{array}{l}\text { Shows the range of applications for } \\
\text { boundary spanning theory at the } \\
\text { individual and organizational } \\
\text { interface. Does not directly relate to } \\
\text { the firm-organizational interface } \\
\text { presented in this research. }\end{array}$ \\
\hline
\end{tabular}


The foundational principles of boundary spanning theory have been applied broadly across individual/external organization and firm/external organization interfaces, but have special implications for this research, as outlined in Table 1. Overall, boundary spanning should lead to improvements in (or increase the effectiveness of) the "system," of the organization as a whole. Thus, external information gathered through boundary spanning should drive firm-level measures, such as firm innovativeness and firm performance. The following section will further explain the ties with Hult's (2011) work on the boundary spanning marketing organization.

\subsection{Boundary Spanning and a Theory of the Boundary-Spanning Marketing}

\section{Organization}

While the theory of boundary spanning emerged in the late 1970s (Adams, 1976; Aldrich and Herker, 1977; Tushman, 1977), it has endured throughout the years, having been applied in the fields of strategy (Ahuja and Katila, 2004; Henderson and Cockburn, 1994; Jonsson, Holmstrom, and Lyytinen, 2009), new product development (de Brentani and Reid, 2012; Lysonski, 1985), team learning (Bresman, 2010), entrepreneurship (Brodzinski et al., 1990; Cooper et al., 1995; Zahra, 2012), and marketing (Hult, 2011).

One of the most recent applications of boundary spanning theory at the firm-level, I will now more closely examine Hult’s (2011) use of boundary spanning theory in the marketing function. G. Tomas M. Hult (2011) focuses on marketing as a key boundary-spanning role in his work to develop a broader vision of the marketing organization. He outlines a theory of the boundary-spanning marketing organization, naming it "MOR theory," standing for Marketing Organizational theory. While MOR theory is focused on the marketing organization and not entrepreneurial firms, it suggests many important considerations for applying boundary spanning 
theory in more specific contexts that may be able to influence outcomes such as innovation and performance for the organization as a whole. Hult (2011, p.509) defines the boundary-spanning marketing organization as:

An entity encompassing marketing activities that cross a firm's internal and external customer value-creating business processes and networks for the purposes of satisfying the needs and wants of important stakeholders.

While useful for firms of any size, this definition’s emphasis on the necessary integration between business processes and stakeholders for establishing and maintaining a successful organization is especially applicable for entrepreneurial firms seeking to build business processes and establish and satisfy the needs of new and existing stakeholders.

The foundational premises of MOR theory represent the integration of thirty-one organizational theories, resulting in four "strength" characteristics important for a successful marketing organization:

(1) strategic market resources,

(2) marketing leadership and decision making,

(3) network alliances and collaborations, and

(4) marketplace operations.

I define each of these strengths individually as presented in Hult (2011), summarize their applicability to boundary spanning theory, and then assert my own applications of MOR theory’s implications for entrepreneurial firms, in the following table (see Table 2): 
TABLE II: MOR THEORY IN ENTREPRENEURIAL FIRMS

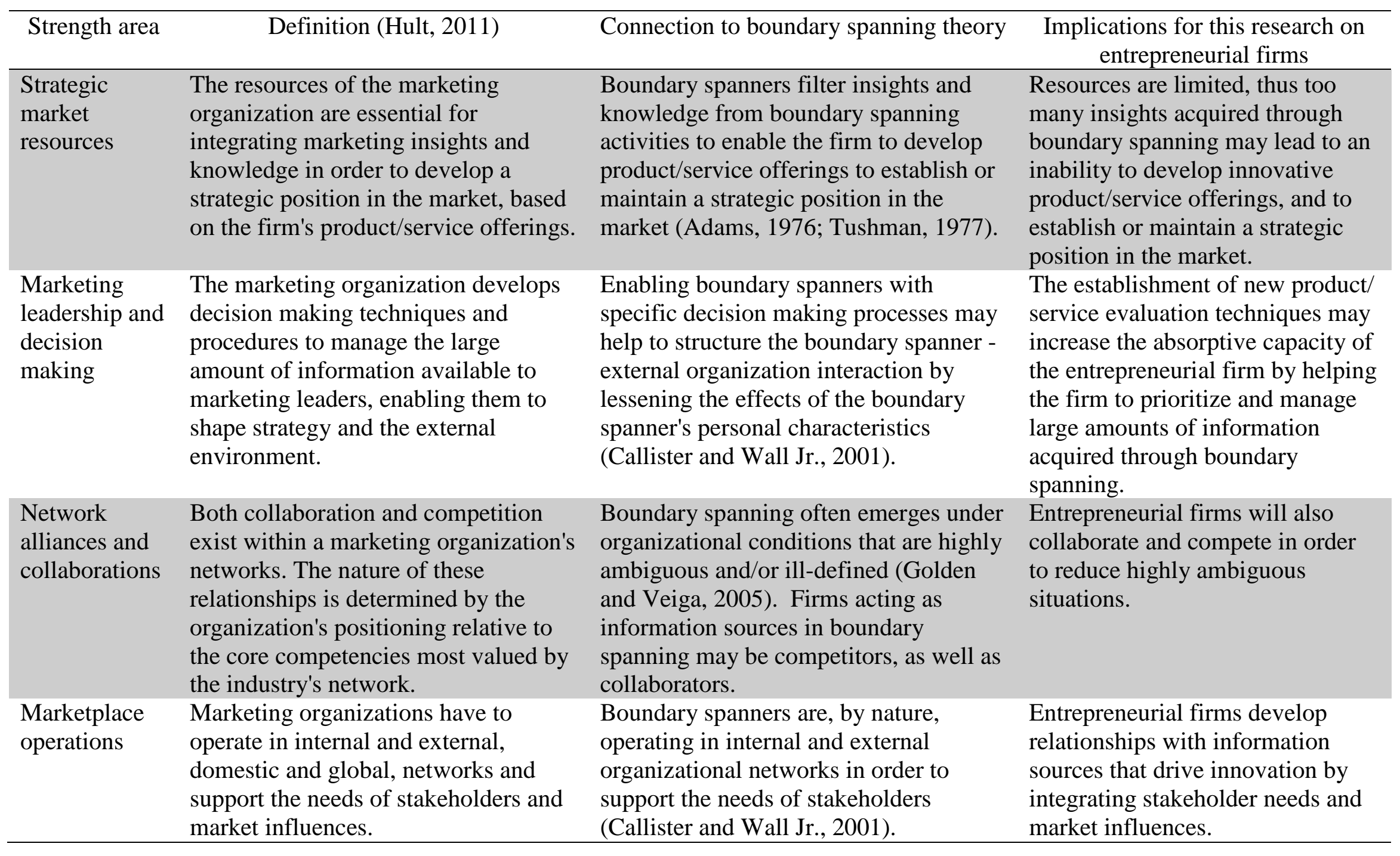


Boundary spanning and MOR theory provide a good theoretical foundation for understanding the critical nature of external information and interacting with external stakeholders in driving innovation. In the following section I examine how boundary spanning has been explored, to a very limited degree, in entrepreneurial firms, specifically.

\subsection{Boundary Spanning in Entrepreneurial Firms}

Entrepreneurial firms that focus on driving innovation and firm performance, which is the focus of this study, can benefit from a positive image in the marketplace in terms of higher brand equity, obtaining better collaboration partners (in the case of this research, better information sources for boundary spanning), and attracting highly skilled employees (Rosenbusch et al., 2011). However, few empirical studies have examined boundary spanning in entrepreneurial firms (Brodzinski et al., 1990; Cooper et al., 1995). Brodzinski, et al. (1990), who conducted one of the few studies of boundary spanning in the entrepreneurial context, called for further investigation into the importance of different types of environmental information for entrepreneurial firms, which this research will begin to address by identifying specific boundary spanning objectives. Cooper, et al. (1995) found that when inexperienced entrepreneurs enter an industry they are not familiar with, they lessen their search for external information, while experienced entrepreneurs engage in the same amount of search whether the industry is new to them or not.

\subsection{Organizational Learning Theory}

Organizations engage in many types of different information searches - including searching for the best ways to implement new innovations or new products (Katila, 2002; Von 
Hippel and Tyre, 1995). Organizational learning is essential for successful organizational adaptation and survival, as well as successful performance (Argote, 1999; Brown and Duguid, 2001; Burgelman and Grove, 2007; Fiol and Lyles, 1985; Hoy, 2008; Rao and Argote, 2006). Learning also enables firms to be entrepreneurial by driving innovation, new business creation, and renewal of operations (Zahra, 2008). Over time, firms tend to narrow their external search efforts and thereby, their organizational learning (Zahra, 2008; 2012). Organizations can maintain their entrepreneurial nature by learning from experience, as well as by engaging in entrepreneurial activities with partners outside of the firm (Burgelman and Grove, 2007; Hoy, 2008; Leonard-Barton, 1992; Pérez-Nordtvedt, Kedia, Datta, and Rasheed, 2008) - as is the case in this research. Through new entrepreneurial activities such as pushing a firm to explore areas beyond its typical internal R\&D activities, new knowledge is created and incorporated into the firm (Zahra, 2012), though integration can be difficult (Zahra, 2008).

Exploration and exploitation are also important for organizational learning (Sidhu, Commandeur, and Volberda, 2007). Multiple definitions of these two concepts have led to broad interpretations, such as March (1991), who included terms such as search, discovery, and innovation for exploration, and production, selection, implementation and execution for exploitation. Koza and Lewin (1998) provide a slightly broader definition of exploration which not only includes innovation, as previously mentioned, but also invention, entering new lines of business, building new lines of business, and investments in the firm's absorptive capacity. Finally, Rothaermel (2001) defined innovation most broadly as the pursuit of new knowledge. This pursuit of new knowledge will be represented in this research by the boundary spanning that the firm chooses to engage in to drive firm innovativeness and performance. 


\section{$2.5 \quad$ The Role of Absorptive Capacity}

The construct of absorptive capacity has evolved and expanded over time, not only by the authors of the original papers on the subject (Cohen and Levinthal, 1989; 1990; 1994), but also through the more than 900 peer-reviewed academic papers which use the construct (see the metaanalysis conducted by Lane et al., 2006). The original works, however, are consistent with boundary spanning theory, MOR theory, and organizational learning theory, in that they emphasize how interacting with the external environment enables a firm to develop processes, policies, and procedures to facilitate sharing knowledge internally, to better understand how to create new products/services and new markets, and to strategically use the firm's resources to commercialize innovations (cf., Adams, 1976; Callister and Wall Jr., 2001; Hult, 2011).

Research addressing the intersection of innovation and absorptive capacity has suggested that absorptive capacity helps the speed, frequency, and magnitude of firm innovativeness (Lane et al., 2006).

The innovation process requires outside sources of knowledge (Cohen and Levinthal, 1990), but mere exposure to external knowledge is not sufficient to internalize it successfully within the organization (Pennings and Harianto, 1992). Up until this point, this research has focused on the acquisition of new knowledge; but, to achieve competitive advantage, firms need to also assimilate that knowledge and apply it to commercial ends (Jansen et al., 2005). Two types of absorptive capacity are introduced in Zahra and George (2002): potential absorptive capacity and realized absorptive capacity. Potential absorptive capacity focuses on the firm's acquisition and assimilation of knowledge (some of which may never be exploited) (Jansen et al., 2005; Zahra and George, 2002). Alternatively, realized absorptive capacity is the firm’s focus on transforming and exploiting knowledge (Zahra and George, 2002). Lichtenthaler (2009) 
includes both learning processes captured by potential and realized absorptive capacity and then goes further to add a third learning process, transformative learning, which finds that maintaining knowledge over time requires a link between gathering new potential knowledge and realizing its benefits for firm innovation and performance, as outlined in Garud and Nayyar (1994) and Lane, et al. (2006). Just as learning processes differ in the ways in which knowledge is integrated into an organization, the objectives with which firms seek out the knowledge in the first place is important to understand. The next section will propose three new boundary spanning objectives with which firms may pursue external knowledge.

\subsection{Boundary Spanning Objectives}

Several studies have attempted to categorize the interactions between firms and the external organizations with which they engage in boundary spanning. For example, in a field study of boundary spanning in the Research and Development (R\&D) facility of a large corporation, Tushman and Scanlan (1981) studied extra-organizational communication, which was divided into two areas: professional areas (communication with universities, professional societies) and operational areas (communication with suppliers, vendors, customers). Cooper, et al. (1995) studied external information sources helpful to entrepreneurs when planning the business and categorized the responses into professional sources (such as accountant, banker, lawyer), and personal sources (such as friends or relatives, other business owners). More recently, Laursen and Salter (2006) divided the external knowledge sources used by the firms they studied into four different “types”: (1) Market sources (suppliers, customers, competitors, consultants, and research and development enterprises), (2) Institutional sources (universities, government research organizations, and private research institutes), (3) Other sources 
(professional conferences, meetings, trade associations, technical/trade press, computer databases, fairs, exhibitions), and (4) Specialized sources (technical standards, health and safety standards and regulations, environmental standards and regulations).

All of these prior studies categorized the external information sources post hoc. In other words, the respondents did not categorize the information sources themselves, or have an opportunity to provide information about the reason that they interacted with this external source. By exploring the objective(s) with which a firm pursues interaction with an information source - engages in boundary spanning with the source - we can determine if these objectives influence firm innovativeness and performance in a way that is more nuanced than previously studied. Leiponen and Helfat (2010) call for a better understanding of the type of information searched, as well as the role of objectives, in research on innovation at the firm level. This research addresses that gap by introducing three specific objectives for furthering innovation with the firm:

Informational boundary spanning: Gathering general industry, market, or product information to stay abreast of trends or new developments.

Operational boundary spanning: Gathering specific information for current use in innovating or improving the day-to-day operations of the firm. This may include ways to better serve existing customers, to better manage inbound, and/or outbound logistics, or to improve financial management activities. 
Strategic boundary spanning: Gathering specific information for an intended future use in innovating or improving the strategic direction of the firm.

The firms participating in the empirical portion of this research indicate the primary purpose for interacting with each information source that they identify as relying on for their innovation activities. Thus, the firm will be identifying its objective for pursuing the boundary spanning activities that it chooses to engage in. In addition to understanding the objectives for boundary spanning, this research is also concerned with better understanding the effects of the extent to which boundary spanning occurs and the influences on firm innovativeness and performance. The next section will discuss the need to consider the breadth and depth of these interactions.

\subsection{Breadth and Depth of Boundary Spanning}

The breadth and depth of interaction with external information sources are important aspects to consider within an organizational learning framework (Zahra, 2012). Breadth refers to the diversity of industries (related, or unrelated to the firm's industry), or areas (such as technology or marketing sources) in which the firm acquires new knowledge; while depth refers to the firm's ability to engage in deep learning, which usually increases the firm's ability to create and exploit new knowledge combinations (Zahra, 2012). Both breadth and depth were found to be conducive to entrepreneurship, with organizational learning identified as a precursor to this outcome. This suggests that breadth and depth of learning through boundary spanning should be a driver of firm innovativeness in the entrepreneurial firm.

Laursen and Salter (2006) studied the relationship between innovativeness and openness to external search at the firm level for the manufacturing industry in the U.K. Through this 
research they emphasized the concepts of breadth and depth as two important areas of consideration for a firm's external search strategies, linking both to innovative performance (Laursen and Salter, 2006). Their findings suggest that firms that search more widely and deeply are generally more innovative; however, the benefits to this openness are subject to diminishing returns, meaning that there is a point where additional search becomes unproductive.

Laursen and Salter (2006) base their research on Chesbrough’s ‘open innovation’ model (Chesbrough, 2003; 2006), which represents that firms seek innovations beyond their own R\&D departments, choosing instead to source successful innovations from a wide range of external sources. While similar to boundary spanning in terms of seeking innovations outside of the organization, open innovation is more narrowly focused on sourcing innovations from existing organizations. Boundary spanning, on the other hand, encompasses a broader picture of external search, focusing on more general interactions between the firm and external information sources including customers, competitors, professional organizations, universities, etc. Nonetheless, the concepts of breadth and depth are also highly relevant in boundary spanning and will be explored in this research.

Additional research has also found that breadth, in the types of information searched, positively affects innovation outcomes (Ahuja and Katila, 2004; Rosenkopf and Nerkar, 2001; Von Hippel, 1988; Zahra, 2012). In one of the first studies to conduct firm-level analyses of the impact of technological innovation breadth on innovation objectives, Leiponen and Helfat (2010) found that having a greater breadth of innovation objectives and knowledge sources is associated with greater firm-level innovation success. They also found no evidence of decreasing returns to a greater number of information sources and objectives. This finding is inconsistent with prior research, which found a curvilinear (an inverted U-shape) relationship between breadth of search 
and innovative performance, suggesting that some firms have a tendency to ‘over-search' (Katila and Ahuja, 2002; Laursen and Salter, 2006) (also the assertion which will be tested in this research). One explanation for this discrepancy could be that Leiponen and Helfat's sample firms had a mean of 318 employees, with an upper boundary of 6,615 employees (Leiponen and Helfat, 2010). With firms this large included in the sample it is likely that these firms had significant resources at their disposal, thus the effects of allocating resources to several boundary spanning sources would not have the same impact that it would for an entrepreneurial firm. Thus, in this research, findings consistent with diminishing returns of over-search are more likely to be found.

The following section will review the literature in each of these areas in more detail and present several hypotheses to test the full conceptual framework and research model. 


\section{CONCEPTUAL FRAMEWORK AND HYPOTHESIS DEVELOPMENT}

\subsection{Boundary Spanning and Firm Innovativeness}

The theories of boundary spanning and organizational learning are intertwined with the concepts of absorptive capacity and innovation, and yet, evidence is still lacking for explaining the role of different sources on knowledge flows (Grimpe and Sofka, 2009; Kostopoulos et al., 2011), and whether absorptive capacity plays a role in translating these knowledge flows into realized benefits such as innovation (Todorova and Durisin, 2007). This research defines three different objectives of boundary spanning to begin to explain the role of different types of information sources on firm innovativeness: informational boundary spanning, operational boundary spanning, and strategic boundary spanning. This distinction is important to assess because, depending on the objective with which the firm engages in boundary spanning, the firm may find a greater breadth or depth of boundary spanning to be the most appropriate for driving firm innovativeness and performance.

Not only do I expect to find that entrepreneurial firms pursue boundary spanning with varied objectives (i.e., informational, operational, strategic), but also that the degree of boundary spanning will also affect firm innovativeness (the breadth of the sources used, as well as the depth of the interactions). Prior research suggests that the intensity (amount of time spent on boundary spanning) and the extensity (number of boundary spanner contacts) of boundary spanning activities are important measures (Katz and Kahn, 1978).

In terms of this research, breadth of boundary spanning represents the number of unique external information sources that a firm relies on for driving innovation (Laursen and Salter, 2006; Zahra, 2012). Firms may vary in the degree to which they seek out knowledge in new industries or areas (such as technology, marketing, etc.), with some firms focusing on only one 
or two sources, versus others who may integrate knowledge from multiple areas (PérezNordtvedt et al., 2008; Zahra, 2012; Zahra, Ireland, and Hitt, 2000). Depth of boundary spanning is the extent to which firms draw deeply from each information source for the purpose of innovation (also based on Laursen and Salter, 2006). Together, breadth and depth of boundary spanning represent the big picture of the entrepreneurial firm's external search, or degree of boundary spanning.

Katila and Ahuja (2002) examined external search breadth and found that a firm's innovative performance was in part a function of its search behavior. They found a curvilinear relationship (an inverted U-shape) between breadth of search and innovative performance. This relationship suggests that some firms have a tendency to 'over-search' (Katila and Ahuja, 2002; Laursen and Salter, 2006). Laursen and Salter (2006) provide three reasons why 'over searching' may have a negative influence on firm performance. First, because there may be too many ideas for the firm to manage and choose between - this is related to the absorptive capacity of the firm. Another reason is that innovative ideas often come at the wrong time and in the wrong place to be fully exploited. And lastly, if there are too many ideas, many may not be taken seriously or given the necessary attention or resources to develop them to the point of implementation.

An example of 'over searching' in an entrepreneurial context can be seen in the following example about entrepreneurial firms seeking external assistance. Chrisman, McMullan and Hall (2005) found that using the assistance of counselors from a Small Business Development Center significantly influenced growth (sales and employment) in new ventures up to a point; however, too much assistance proved to be a hindrance to sustaining high levels of growth. This example uses the dependent variable of firm growth, rather than firm innovativeness, but the findings 
suggest that the relationship would be similar between boundary spanning and firm innovativeness for entrepreneurial firms.

Additionally, in terms of depth of boundary spanning, innovative firms often draw intensively from a small number of external information sources (Laursen and Salter, 2006). With regards to boundary spanning, this suggests that some firms will gather external information from a small number of key information sources for the purpose of enhancing firm innovativeness. While firms that draw extensively from external sources tend to be more innovative due to building strong relationships, some firms can also become too reliant on external sources for innovation (Laursen and Salter, 2006).

By gathering knowledge from external sources, a firm seeks the ability to make new connections or reach new conclusions by integrating across diverse knowledge bases (Huber, 1991; Pérez-Nordtvedt et al., 2008; Zahra et al., 2000). However, similar to arguments about breadth, depth of boundary spanning information search activities is also a double-edged sword. On one side, deep learning from external sources can spur innovation by creating or exploiting new knowledge combinations (lack of deep interactions may not drive this learning); but on the other side, this depth of learning can also slow down information processing within the firm, constraining the firm's ability to respond effectively to changing environmental conditions (Zahra, 2012). Thus, for depth of boundary spanning, the relationship is expected to have an optimal number of information sources, with too few and too many deep interactions leading to negative effects on firm innovativeness.

Thus, given the different objectives of boundary spanning, as well as the depth and breadth of boundary spanning for each objective (informational, operational, strategic), the following hypotheses will be explored in this research: 
Hypothesis 1a: Breadth of boundary spanning is curvilinearly (an inverted U-shape) related to firm innovativeness.

Hypothesis 1b: Depth of boundary spanning is curvilinearly (an inverted U-shape) related to firm innovativeness.

In addition to breadth and depth of boundary spanning predicted to have an initially positive effect on firm innovativeness, followed by a period of diminishing returns, and then a possible negative relationship based on problems associated with over-search (Katila and Ahuja, 2002; Laursen and Salter, 2006), this research has proposed that the three objectives with which firms seek to engage in boundary spanning activities may have unique effects on firm innovativeness. This is consistent with Rosenbusch, et al.’s (2011) finding that Small or Medium-sized Enterprises (SMEs) benefit significantly more from having a focus on strategic innovation, rather than just focusing on developing new innovative products. This finding is interpreted here for entrepreneurial firms, that boundary spanning pursued with a strategic objective will reach the point of diminishing returns for firm innovativeness later than that pursued with an operational or information objective, because the focus of these interactions is longer term, and more directly connected with innovating, or improving the strategic direction of the firm. Further, for operational boundary spanning, the focus in still on innovating, but in a less strategic way, and thus, this form of boundary spanning would reach a point of diminishing returns more quickly than that of strategic boundary spanning, and perhaps less quickly than more general informational boundary spanning. In fact, informational boundary spanning, as defined 
previously, is focused on gathering general industry, market, or product information, and is not inherently strategic in nature, and would be expected to reach a point of diminishing returns for firm innovativeness more quickly than strategic or operational boundary spanning. The following two hypotheses represent these proposed relationships:

Hypothesis 2a: The effect of entrepreneurial firm boundary spanning that is strategic in nature will have a higher inflection point than operational and informational boundary spanning.

Hypothesis 2b: The effect of entrepreneurial firm boundary spanning that is operational in nature will have a higher inflection point than informational boundary spanning.

\subsection{Boundary Spanning, Absorptive Capacity, and Firm Innovativeness}

As defined previously, absorptive capacity is the firm's ability to value, assimilate, and commercially utilize new, external knowledge (Cohen and Levinthal, 1990). The fact that valuable (or potentially valuable) knowledge exists in the external environment is a necessary, but not sufficient, condition for a firm to develop absorptive capacity (Lane et al., 2006). Thus, absorptive capacity on its own is not sufficient for firm innovativeness.

Prior literature has called for a better understanding of environmental influences on external knowledge acquisition and of interactions between learning processes and absorptive capacity (Lane et al., 2006; Tsai, 2001). Studies have looked at the learning processes of absorptive capacity and their influences on innovation and performance at the firm level with respect to exploratory learning, which refers to acquiring external knowledge, and exploitative 
learning, which is the application of the acquired knowledge (Zahra and George, 2002), as well as transformative learning, which links the first two processes through maintaining knowledge over time (Garud and Nayyar, 1994). While the construct of boundary spanning overlaps in theory with the exploratory learning process, the specific boundary spanning piece of this research is objective-driven, meaning that the firm is acquiring knowledge with a specific objective in mind (informational, operational, strategic).

Further delineating the absorptive capacity construct from boundary spanning is the effect of the interaction of the three learning processes (exploratory learning, exploitative learning, and transformative learning), which go beyond boundary spanning to include the application and maintenance of the acquired knowledge. The constructs are related, but distinct. An interaction effect is hypothesized, which would strengthen the effect of breadth and depth of boundary spanning on firm innovativeness in the case of high absorptive capacity, thus:

Hypothesis 3: The relationship between entrepreneurial firm boundary spanning and firm innovativeness is moderated by the absorptive capacity of the firm.

\subsection{Firm Innovativeness and Firm Performance}

Extant research has asserted that innovation capability is the most important determinant of firm performance (Mone, McKinley, and Barker, 1998), a finding that is supported by other empirical studies (e.g., Cooper and Kleinschmidt, 1987; 2000). Firms must be innovative in order to gain a competitive advantage, crucial to survival in a competitive marketplace (Li and Calantone, 1998). Also, it is through innovation that firms respond to environmental demands, 
thereby maintaining or improving their performance in the marketplace (Damanpour, Walker, and Avellaneda, 2009).

Schumpeter (1934) asserted that innovation was the vehicle through which entrepreneurial firms gain profits - through the temporary establishment of a monopoly, an advantage that could be maintained through continuous innovation activity. More recent studies have reinforced this concept through findings that competitive advantage in entrepreneurial firms is driven by the recombination of resources and the realization of innovation through implementing value-creating strategies (Branzei and Vertinsky, 2006; Grant, 1996).

However, despite the many findings in support of a positive relationship between these two constructs, Rosenbusch et al. (2011) found that factors such as age of the firm, the type of innovation, and cultural context all effect the impact of innovation on firm performance and may lead to stronger or weaker relationships between these two variables. On the balance, despite the debate in extant literature, the smaller, nimbler structures of entrepreneurial firms have been found to profit from adjusting to environmental changes more quickly than larger, more hierarchical organizations (Nooteboom, 1994). Thus, in this study I assert the following:

Hypothesis 4: Firm innovativeness is positively related to firm performance. 


\subsection{Research Model}

\section{Figure 1: Research Model}

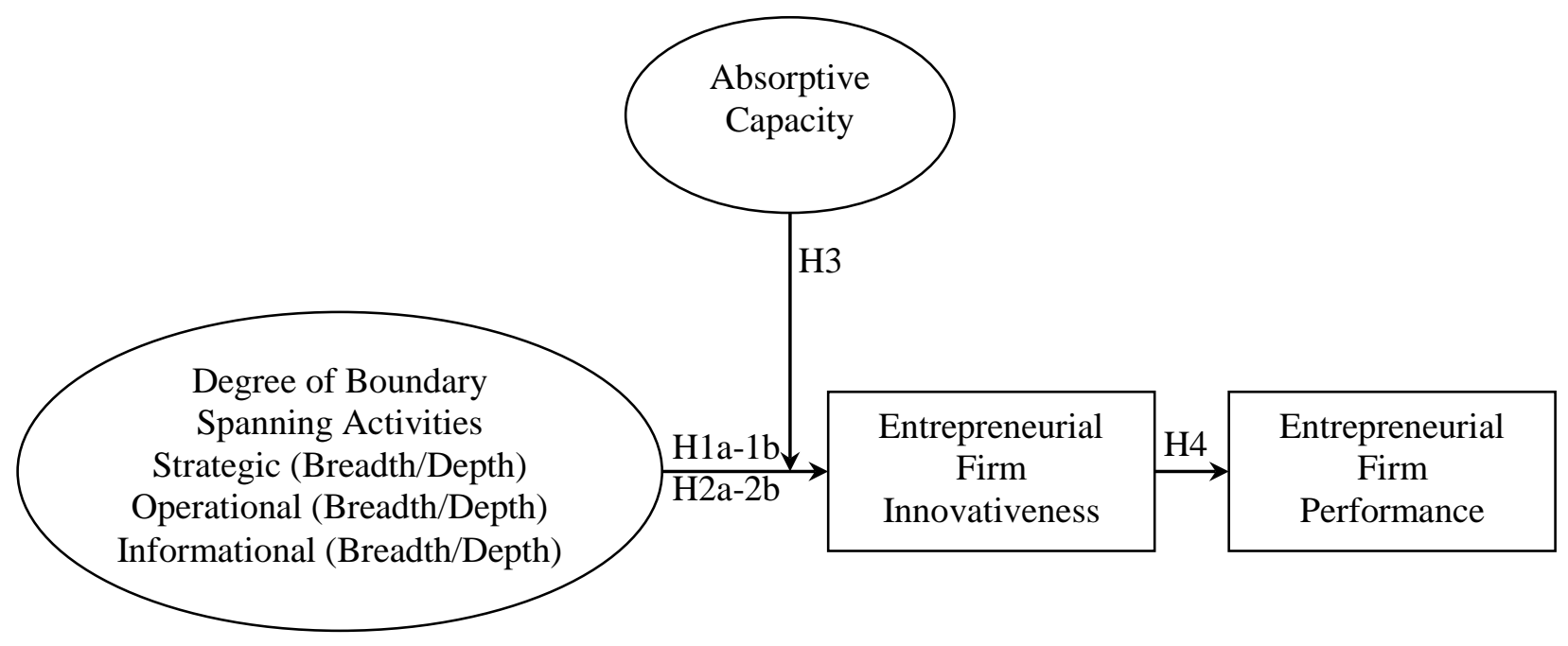




\section{METHODS}

\subsection{Research Procedures and Sample}

After receiving approval from the Institutional Review Board of the University of Illinois at Chicago, I conducted an online survey (in Qualtrics) of individuals who are the founders of, and/or strategic decision makers in, entrepreneurial firms. Dollinger (1984) found in his research on boundary spanning in entrepreneurial firms that the owner/operator is the dominant boundary spanner in the organization and that boundary spanning activity is a major entrepreneurial role. Based on this finding, I identified the founder and/or a strategic decision maker within the firm as the dominant boundary spanner and asked them respond on behalf of the firm. Further support for having the firm founder and/or a strategic decision maker as the primary respondent on behalf of the firm can be found in the strategy literature, which deems members of the top management team as suitable respondents for measuring organization-level constructs (Conant, Mokwa, and Varadarajan, 1990).

While asking the individual to report on firm-level constructs, as is common in the entrepreneurship literature, to avoid confusion on whether the survey questions related to the individual respondent or the firm, I carefully designed each survey item in the plural form, consistent with the approach used by Sidhu, et al. (2007). For example, a question asking “To what degree do you agree with the following statements about your firm’s industry?” would be followed by a statement such as, "The product and service obsolescence rate in our industry is very high.”

Entrepreneurial firms were operationalized in this study as firms that were foundermanaged and had been vetted by panels of experts as being successful entrepreneurial organizations (for example, firms inducted into the Entrepreneurship Hall of Fame must have 
revenues greater than $\$ 5$ million and must have contributed some sort of innovation in their business). The firms also qualify as "small businesses" according to the size standards of the Small Business Administration.

This survey was rolled out in three phases. Phase 1 was initiated with a small sampling frame to confirm the face validity of the survey itself and to highlight any potential issues with survey administration. Entrepreneurs whom I knew personally completed the survey on behalf of their firms. After the survey, I provided the opportunity for this sample to provide questions or comments about the survey. No comments were received, and so the survey was used without changes in future phases of the data collection. Seventeen surveys were started during phase 1, 10 were completed in full, and where possible, partially completed surveys were also included for a total of 15 surveys from this sample with at least some usable data.

The second phase of the survey targeted entrepreneurial firms through the Small Giants organization. I chose this organization because it represented a form of boundary spanning as a networking group for entrepreneurs. Additionally, the entrepreneurial firms engaged in this professional organization would likely choose the firm's key boundary spanner to represent the firm as a member, and the potential respondent to this survey. As described on their website (Small Giants Community, 2013):

The Small Giants Community is made up of small business leaders all over the world who define success by more than just their financial bottom lines, but also by their contributions to their communities, a dedication to great customer service and the creation and preservation of workplace cultures of excellence.

The survey participation request was sent out in the September e-newsletter of the Small Giants Community and also posted on their Twitter feed and Facebook page. This request resulted in 
10 completed surveys and 2 partially completed surveys. The organization did not provide reminder emails to accompany the newsletter and e-blasts, which reduced the response rate.

Phase 3 of the survey was conducted through the Chicago Area Entrepreneurship Hall of Fame, managed through the University of Illinois at Chicago's Institute for Entrepreneurial Studies. The firms inducted into the Hall of Fame have demonstrated entrepreneurial talent by founding and/or growing a local business. This sampling frame was selected because the firms have been recognized for their entrepreneurial success, confirming their status as entrepreneurial firms. The awards have been presented for the past 27 years (since 1985). The survey was sent to 244 members of the Entrepreneurship Hall of Fame. Seventy-four individuals started the survey, and 37 completed it, with 58 surveys containing at least partial usable data.

I used an online survey, prepared and administered through Qualtrics, to collect the data in all three phases of this study. Potential respondents received an email explaining the study and asking for their participation. The individuals then clicked on a link which took them directly to the Qualtrics website with the survey. Data were collected from August to November 2012. See Table 3 for a summary of response rates for each phase. Independent-Samples T tests were conducted to determine differences between the three samples on the independent, dependent and control variables. Since no significant differences were found, the samples were consolidated into one dataset for all future analyses. 
TABLE III. SAMPLING FRAMES AND RESPONSE RATES

\begin{tabular}{lcccc}
\hline & $\mathbf{1}$ & $\mathbf{2}$ & $\mathbf{3}$ & $\mathbf{4}$ \\
\hline Contact Sources & $\begin{array}{c}\text { No. of firms in } \\
\text { sampling } \\
\text { frame }\end{array}$ & $\begin{array}{c}\text { Responses } \\
\text { (including } \\
\text { missing data) }\end{array}$ & $\begin{array}{c}\text { Complete } \\
\text { Responses }\end{array}$ & $\begin{array}{c}\text { Response Rate } \\
\text { (including } \\
\text { missing data) }\end{array}$ \\
$\begin{array}{l}\text { Phase 1: } \\
\text { Entrepreneurs }\end{array}$ & 20 & 17 & 10 & $85.0 \%$ \\
$\begin{array}{l}\text { Phase 2: } \\
\text { Small Giants } \\
\text { Community }\end{array}$ & $\begin{array}{c}300 \\
\text { (estimate) }\end{array}$ & 12 & 10 & $0.4 \%$ \\
$\begin{array}{l}\text { Phase 3: } \\
\text { Entrepreneurship } \\
\text { Hall of Fame }\end{array}$ & 244 & 74 & 37 & $30.3 \%$ \\
Total & 564 & 103 & 57 & $18.3 \%$ \\
\hline
\end{tabular}

After the respondent consented to participating in the research, the survey began with two screening questions to ensure the individual taking the survey met the appropriate criteria for the sampling frame. The first question asked, “Are you the founder of this firm?” The second question asked, “Are you actively involved in strategic decision making within this firm?” The respondent must be either the founder or a strategic decision maker within the firm to continue on with the rest of the survey. Eighty-two percent of the participants indicated that they were the founder of the firm and $96 \%$ indicated that they were actively involved in strategic decision making within the firm. Of the respondents who continued on with the survey beyond these screening questions, all were strategic decision makers within the firm. Three respondents indicated that they were the firm founder, but not a strategic decision maker within the firm. In talking with one such respondent, he indicated that he was retired and no longer involved in the day-to-day operations of the business. This may have also been the case for the other two 
respondents, but they did not report the reason directly. These individuals were screened out of completing the reminder of the survey. There was only one participant who was neither the founder nor actively involved in the strategic decision making of the firm and this individual was also screened out and did not continue on with the survey.

Table 4 provides a summary of the job titles of the survey participants:

TABLE IV: SUMMARY OF JOB TITLES OF SURVEY PARTICIPANTS

\begin{tabular}{lc}
\hline Title & $\#$ \\
\hline CEO & 25 \\
President & 19 \\
Chairman & 9 \\
President \& CEO & 7 \\
Chief Brand Officer, Chief Experience Officer, Chief Procurement & 6 \\
Officer, Chief Values Officer, Chief Innovation Officer, Chief Medical & \\
Officer & \\
Owner/Founder & 4 \\
Executive Vice President & 4 \\
Chairman \& CEO & 2 \\
Principal & 2 \\
Business Manager & 2 \\
\hline Business Development & 1 \\
Marketing Director & 1 \\
\hline M\&A Advisor & 1 \\
\hline
\end{tabular}




\section{2 $\quad$ Measures}

\section{Dependent Variables}

Firm Innovativeness. While Gartner (1988) argued that the correlation of entrepreneurship with innovation is problematic because of identifying which firms are truly innovative, many studies have found innovation to be an appropriate dependent variable, and a measurable one. Innovativeness has been measured through patent citation data, or patent counts (Ahuja and Katila, 2001; 2004; Vanhaverbeke, Beerkens, Duysters, and Gilsing, 2004); however, this approach has several shortcomings as an indicator of innovative performance. First, most patents are not commercialized, and second, many innovations are only partially covered by patent protection - or not patented at all (Klevorick, Levin, Nelson, and Winter, 1995; Levin et al., 1987). In the survey, innovation was defined as "developing a new product or service idea, a new process technology, a new business model, a new organizational form, and so on” (Snow, 2007, p. 101).

In this study, firm innovativeness was operationalized consistent with previous studies (He and Wong, 2004; Manu, 1992; Sidhu et al., 2007), specifically as the percentage of sales accounted for by new products or services introduced in the past three years. The results that follow are based on this objective measure, however additional perceptual measures of firm innovativeness were also assessed to ensure the convergent validity of this dependent variable.

The first perceptual measure collected asked respondents "To what degree is your firm participating in innovation activities?” Responses were measured on a four-point Likert scale from "not at all” to "high degree." The next measure was a six-item scale developed in Hurt et al. (1977) and Hurt and Teigen (1977) and validated in later studies (e.g., Calantone, Cavusgil, and Zhao, 2002; Hollenstein, 1996). Sample items from this scale include, "Our firm frequently 
tries out new ideas," and "Our firm seeks out new ways to do things.” The responses were measured on a five-point Likert scale, ranging from " $1=$ strongly disagree" to " $5=$ strongly agree." Significant, positive correlations were found between the objective measure of firm innovativeness used in the analyses and the scale measure $(r=0.28, p<0.10)$, as well as between the objective measure and the single-item perceptual measure $(r=0.37, p<0.01)$.

Firm Performance. Entrepreneurship research has yet to reach a consensus on the appropriate measure(s) for assessing entrepreneurial firm performance (Murphy, Trailer, and Hill, 1996). Some studies use the objective measure of return on sales as an effective operationalization of this construct (cf. Sidhu et al., 2007). This measure is especially relevant for this research because the other dependent variable, firm innovativeness, is measuring the percentage of sales accounted for by new products or services introduced in the past three years. This percentage should be consistent with higher return on sales if firm innovativeness is driving firm performance. Since the majority of firms in this study are privately held, the respondent reported the return on sales on behalf of the firm.

Other measures of firm performance in the survey were return on assets, as well as a perceptual four-item scale measure asking the respondent to select the option which best estimates how the firm compares to similar firms in the industry and region. The scale items were: return on assets, return on sales, firm sales growth over the past 3 years, and overall firm performance / success. The responses were measured on a five-point Likert scale including the options of "lowest 20\%," “lower 20\%,” “middle 20\%,” “next 20\%,” and “top 20\%” (adopted from Pearce II, Robbins, and Robinson Jr., 1987). A significant, positive correlation was found between the objective measures of return on sales and return on assets $(r=0.59, p<0.01)$. There was not a significant relationship between the objective measures and the subjective scale 
measurement of performance. One explanation for this is the low number of responses on the return on sales measure. Most of the firms included in the survey are privately held and chose not to provide this information (only a $46 \%$ response rate to this question). There was a much higher response rate on the perceptual scale items (80\%). The four-item scale did have good reliability (Cronbach’s alpha $=0.93)$ and the correlation between the return on sales item within the scale had a significant, positive correlation with each of the other scale items of return on assets $(r=0.86, p<0.01)$, firm sales growth over the past 3 years $(r=0.72, p<0.01)$, and overall firm performance / success $(r=0.76, p<0.01)$. Despite the low response rate on the self-reported return on sales survey item, this measure most accurately reflects objective firm performance and thus was used to assess firm performance in the final analysis of the research model.

\section{Independent Variables}

Boundary Spanning. Boundary spanning has been studied as activities accessing different types of information sources for innovation and the extent to which those interactions are pursued (Dollinger, 1984; Laursen and Salter, 2006; Leiponen and Helfat, 2010). This research presents a new way to look at the construct of boundary spanning and information sources, in that the primary purpose for interacting with each source is hypothesized to drive unique effects on firm innovativeness. Survey participants were presented with a list of boundary spanning information sources. Sixteen of these activities were adopted from the U.K. innovation survey, implemented in 2001 and based on the core Eurostat Community Innovation Survey (CIS). The CIS questionnaire has its foundation in prior innovation research including the Yale survey and the Science and Technology Policy Research (SPRU) innovation database 
(cf. Cohen and Levinthal, 1990; Klevorick et al., 1995; Levin et al., 1987). This research follows the use of the measure as operationalized in Laursen and Salter (2006), which used all 16 external sources listed in the U.K. survey. In this research, I include three additional activities: specifically, "Employees of your own firm," "Social media (such as Twitter, Facebook, LinkedIn, blogs)," and "General internet searches” to account for new ways in which firms may be gathering external information. For each of the external sources, participants were asked to identify to what degree the firm relies on the source of information for its innovation activities. "Innovation activities” were defined as activities which include "developing a new product or service idea, a new process technology, a new business model, a new organization form, and so on” (Snow, 2007, p. 101). Response options included, "not used,” "low,” “medium,” and "high” degree.

For each of the information sources used for innovation, participants were then asked to select a primary, and if applicable, secondary, or other, purpose for the firm's innovation activities based on three provided definitions for informational, operational, and strategic purposes. This is the first known study to allow the respondent to categorize the purpose with which the firm pursued the interaction with the information source. The following are the definitions provided in the survey:

- Informational: Gathering general industry, market, or product information to stay abreast of trends or new developments.

- Operational: Gathering specific information for current use in innovating or improving the day-to-day operations of the firm. This may include ways to better serve existing customers, to better manage inbound and/or outbound logistics, or to improve financial management activities. 
- Strategic: Gathering specific information for an intended future use in innovating or improving the strategic direction of the firm.

The key independent variables in this study represent the informational, operational, and strategic breadth and depth of knowledge sources that the firm utilized in its innovation activities. As a further application of boundary spanning objectives, I introduce two new variables for each objective with which firms pursue information sources for innovation activities: breadth and depth (thus, informational breadth/depth, operational breadth/depth, and strategic breadth/depth).

Boundary spanning breadth is the number of unique information sources the entrepreneurial firm engages with in boundary spanning activities. Similar to the procedure used in Larsen and Salter (2006), Mol and Birkinshaw (2009), and Leiponen and Helfat (2010) each of the 19 information sources are coded as a binary variable, with 0 representing that the source was not used, and 1 representing usage of the particular information source (if the participant indicated that the firm relies on the source of information for its innovation activities to a "low," “medium,” or "high” degree). This variable has a high degree of internal consistency (Cronbach's alpha $=0.86)$. Next, the sources which were used and indicated as having an informational primary purpose were summed so that each firm gets a 0 if no information sources were used, and the firm gets a value of 19 if all information sources were used and marked as informational in nature. This process was repeated for operational and strategic, so that each firm has a "breadth" value for each boundary spanning objective.

Boundary spanning depth is the extent to which firms rely intensively on some information sources for innovative ideas (Laursen and Salter, 2006). It was operationalized similarly to boundary spanning breadth, but rather than being based on simple use of the source, 
depth represents a “medium” or "high" degree of use of the information source for innovation activities. While Laursen and Salter (2006) used only a "high" degree of use of the information source for their depth measure, leaving out moderate use seemed too strict of a measure, especially given the subjective nature of the difference between the two terms, so the depth measure in this research includes both moderate or high use of the information source. Thus, low degree of use, or no use, of the information source were represented with a binary value of 0 , while moderate or high use of the information source was coded as a value of 1 . This measure also has a good level of internal consistency (Cronbach's alpha $=0.77$ ). Next, the sources which were used to a moderate or high degree and indicated as having an informational primary purpose were summed so that each firm gets a 0 if no information sources were used, and the firm gets a value of 19 if all information sources were used to a moderate or high degree and marked as informational in nature. This process was repeated for operational and strategic, so that each firm has a “depth” value for each boundary spanning objective.

The boundary spanning measure included in this research also allowed participants to indicate a secondary purpose (informational, operational or strategic), as well as any other purpose (informational, operational or strategic) for each information source they selected that they rely on for innovation activities. For purposes of this dissertation, and for testing the concept with the most conservative measure (i.e., not confounding results by also including the secondary purpose along with the primary purpose), only the primary objective will be used in the following analyses. In total, six boundary spanning measures will be used to analyze the research model: informational breadth and depth, operational breadth and depth, and strategic breadth and depth. 


\section{Moderating Variable}

Absorptive Capacity. In measuring absorptive capacity, I adopted a measure of absorptive capacity developed in Lichtenthaler (2009) to take into account the learning process that takes place within organizations, based on the complimentary nature of exploratory and exploitative learning processes. The measures were developed based first on related constructs which look separately at exploratory and exploitative learning processes (Jansen et al., 2005; Smith, Collins, and Clark, 2005; Szulanski, 1996), and then enhanced with findings from interviews with the head of R\&D or a high-ranking technology manager within medium- and large-sized industrial firms, to form the final measurement scales. All scales were assessed using a 5-point Likert scale where “ $1=$ strongly disagree” and “5=strongly agree.”

The three learning processes in the absorptive capacity measure are divided into six subscales to represent the different stages of the process (Lichtenthaler, 2009). Exploratory Learning includes the firm's activities related to scanning and monitoring the environment, as well as the observation of external information sources, in a 5-item scale titled Recognize. This process also includes a 4-item scale, Assimilate, which captures the absorption of knowledge from external information sources. Transformative Learning is comprised of a four-item scale, Maintain, which represents the firm’s activities related to sharing knowledge and communicating within the firm, and the four-item scale, Reactivate, which measures if a firm can react to opportunities by activating stored knowledge. Lastly, Exploitative Learning is made up of the four-item scale Transmute, which represents the firm's ability to combine new and existing knowledge, and the four-item scale Apply, which measures the degree to which the firm implements adaptations to products and services. 
Since the Lichtenthaler (2009) study was focused on medium- and large-sized industrial firms, the wording of some scale items was modified to make them appropriate for small firms, as well as product- or service-based firms. For example, in the Exploratory Learning-Recognize scale, "We frequently scan the environment for new technologies" was changed to "We frequently scan the environment for new product/service ideas.” Five of the six sub-scales had acceptable reliability, consistent with Lichtenthaler (2009) (see Table 5). In the study, the three primary learning processes had direct effects on innovation and performance, but their complimentarity did not result in incremental explanatory power, hence a full, 3-factor measure for absorptive capacity was used in all further analyses of the research model.

TABLE V: RELIABILITY ANALYSIS OF ABSORPTIVE CAPACITY SCALE

\begin{tabular}{|c|c|c|c|}
\hline Scale & $\begin{array}{l}\text { Valid } \\
\text { Cases }\end{array}$ & No. of Items & Cronbach's alpha \\
\hline \multicolumn{4}{|l|}{ Exploratory Learning } \\
\hline Recognize & 63 & 5 & 0.70 \\
\hline Assimilate & 62 & 4 & 0.61 \\
\hline Exploratory Learning - Combined & 62 & 9 & 0.76 \\
\hline \multicolumn{4}{|l|}{ Transformative Learning } \\
\hline Maintain & 60 & 4 & 0.72 \\
\hline Reactivate & 60 & 4 & 0.72 \\
\hline Transformative Learning - Combined & 60 & 8 & 0.74 \\
\hline \multicolumn{4}{|l|}{ Exploitative Learning } \\
\hline Transmute & 56 & 4 & 0.80 \\
\hline Apply & 56 & 4 & 0.81 \\
\hline Exploitative Learning - Combined & 56 & 8 & 0.88 \\
\hline Full 3-factor ACAP scale & 56 & $25^{*}$ & 0.79 \\
\hline
\end{tabular}


While several studies measuring absorptive capacity have relied on R\&D intensity to measure this variable (Lane and Lubatkin, 1998; Mowery, Oxley, and Silverman, 1996), this narrow measure focuses only on technological knowledge, and undervalues the contribution of market knowledge (March, 1991; Todorova and Durisin, 2007). The broader measure of absorptive capacity as complimentary learning processes is more comprehensive and inclusive, and thus will be more representative of the broad array of innovations pursued by the firms in this study.

\section{Control Variables}

In order to be able to appropriately test the proposed hypotheses, several organizational and environmental control variables were included in the analyses. Firm size has been suggested to affect innovation and performance (Dougherty and Hardy, 1996; Meyer, 1982; Sidhu et al., 2007), especially when looking at absorptive capacity, because larger firms may have more resources at their disposal (Jansen et al., 2005), such as financial and human resources, which may enable them to achieve innovation more easily, and to achieve higher sales due to a larger base of customers (Leiponen and Helfat, 2010). Thus, I controlled for firm size, which is used in the analyses as the natural logarithm of the number of full-time employees in order to normalize size since the range was quite large (from 3 employees to 500) (cf. Fang, 2008). Additionally, because older organizations are likely to be less innovative (Dougherty and Hardy, 1996; Meyer, 1982; Sidhu et al., 2007), firm age was used as a control variable. The natural logarithm of firm age was used in the analyses to reduce the distribution (originally ranged from 1 year to 50 years). Firms in several different industries were surveyed, thus industry effects were included 
as a control variable as well (Ensley, Pearson, and Amason, 2002). I include eight industry dummy variables to account for industry-specific effects.

I also controlled for the level of formalization within the firm, which may interfere with innovation efforts if there is an overemphasis on rules (Aiken and Hage, 1968; Burns and Stalker, 1961; Sidhu et al., 2007). Formalization is measured using a 5-item scale which asks to what degree the participant agrees with statements about rules and regulations, written records, and procedures within the firm (Damanpour, 1991). All items were measured on a 5-point Likert scale ranging from “ $1=$ Strongly Disagree” to " $5=$ Strongly Agree”, and the measure had a good level of internal consistency (Cronbach’s alpha $=0.85$ ). Finally, I controlled for environmental dynamism consistent with similar studies looking at firm innovativeness and performance (cf., Sidhu et al., 2007). Dynamism was measured using a three-item scale that asked the participant to indicate his or her level of agreement with statements about the pace of technological change in the firm’s industry, as well as R\&D activity and rate of product or service obsolescence. These items were also measured on a 5-point Likert scale anchored by "Strongly Disagree” and “Strongly Agree.” The Cronbach’s alpha for this scale was 0.80, which is consistent with prior literature using this measure and is within acceptable range.

\subsection{Survey Bias Assessment}

Once data collection was complete, I completed an analysis of the non-response bias consistent with Armstrong and Overton (1977). Survey participants were categorized into early and late respondent groups based on whether they completed the survey within one week (early respondents) or after one week (following a reminder email: late respondents). The early and late respondent groups were compared using an Independent-Samples T test for 21 variables - 
independent, dependent, moderating, and control variables. No significant differences were found at the $p<0.05$ level with the exception of firms identifying themselves in the manufacturing industry. All future analyses control for industry and thus this difference between respondent groups should be accounted for:

- Independent variables: informational boundary spanning breadth $(p=0.50)$ and depth ( $p=0.75)$; operational boundary spanning breadth $(p=0.39)$ and depth $(p=0.20)$; strategic boundary spanning breadth $(p=0.74)$ and depth $(p=0.21)$.

- Dependent variable and moderating variables: firm innovativeness $(p=0.24)$ and firm performance ( $p=0.58)$; absorptive capacity $(p=0.99)$.

- Control variables: number of employees (log) $(p=0.10)$, firm age (log) $(p=0.12)$, level of formalization ( $p=0.77)$, industry dynamism $(p=0.99)$, internet industry ( $p=0.17)$, finance industry $(p=0.55)$, healthcare industry $(p=0.16)$, manufacturing industry $(p=0.01)$, retail industry $(p=0.67)$, services industry $(p=0.39)$, transportation industry $(p=0.16)$, communications industry $(p=0.46)$.

\subsection{Common Method Bias}

One of the main sources of measurement error in behavioral research is method bias, such as common method bias, which is variance that can be attributed to measurement methods, rather than to the constructs themselves (Podsakoff, MacKenzie, Lee, and Podsakoff, 2003). This type of error can threaten the validity of research conclusions both randomly and systematically (by providing an alterative explanation for an observed relationship) (Bagozzi and Yi, 1991; Nunnally, 1978). The common method bias that is most concerning for this study is the effect of using a common source for the predictor and criterion variables. In this case, the 
survey participant is providing both the measure of the independent variable (boundary spanning activities), as well as the dependent variables (firm innovativeness and firm performance).

The entrepreneurial firms surveyed in this research are primarily privately held and are not required to publish their financial data. Additionally, the survey introduction assures participants of their anonymity, cited by Podsakoff, et al. (2003) as a procedure used to reduce method biases, but one that prevents me from knowing the names of the individual firms that responded to the survey, and thus determining any potential publically available financial information. Due to this limitation, participants were asked to provide both perceptual responses regarding the innovativeness of their firm, as well as objective responses regarding their firm’s Return on Assets and Return on Sales figures. Ensuring the accuracy of the reported data is therefore difficult. Further, the number of firms that reported Return on Sales data for 2011 is quite low, thus preventing the possibility of statistically confirming similarities within industry groups in the sample.

One widely used test to address common method variance is Harman's one-factor (or single-factor) test (Podsakoff et al., 2003). Consistent with prior research which has relied on this technique (cf. Andersson and Bateman, 1997; Aulakh and Gencturk, 2000; Greene and Organ, 1973; Organ and Greene, 1981), I loaded all of the variables in my study into an exploratory factor analysis and then examined the unrotated factor solution in order to determine the number of factors necessary to account for the variance in the variables. The results of Harman's test suggest that if a single factor emerges from this factor analysis, or if one general factor accounts for the majority of the covariance among the measures, common method variance is present (Podsakoff et al., 2003). In the exploratory factor analysis, four factors emerged with eigenvalues greater than 1.0 and no factor accounted for the majority of the 
covariance, thus the results seem to indicate that common method variance should not be a concern in the study.

\subsection{Validity and Reliability of the Study}

To be valid, a measure must be reliable - in the words of Kerlinger (1986, p. 417), “Are we measuring what we think we are measuring?” Validity is not about a single number, or result, but rather is a combination of different types of validity such as content, convergent, and divergent validity (Kerlinger, 1986). When looking at validity in terms of scaled measures, both validity and reliability are important. A scale is reliable if it consistently produces the same measurement or category again and again for a given type of response, regardless of who conducts the measurement (Myers and Mullet, 2003). Validity is also necessary to ensure that the reliable scale is measuring what it is intended to measure. In this study, coefficient alpha was used to measure the reliability of the scales included in the research model because this measure is generally considered to be the best estimate of the true reliability of any multiple-item scale (Myers and Mullet, 2003).

Content validity, or face validity, is the extent to which a measure represents what is being assessed. The objective of this form of validity is to ensure that the scale items represent the construct in a way that is consistent with theoretical and practical considerations (Hair Jr, Black, Babin, and Anderson, 2009). In this study, established scales are used, or minimally modified, for the measurement of the key constructs such as boundary spanning activities, absorptive capacity, firm innovativeness, and firm performance, which help to ensure the content validity of the scales in that they are grounded in prior theory, as well as shown to measure what they set out to measure. 
The reliability measure used in this study is internal consistency, which assesses the consistency among the variables within a summated scale, also known as Cronbach’s alpha (Hair Jr. et al., 2009). The generally agreed upon threshold for Cronbach’s alpha is 0.70 (Nunnally, 1978), meaning that the alpha should be greater than, or equal to, 0.70 . The Measures section provides the Cronbach's alphas for each of the summated scales and all meet the 0.70 threshold. The Cronbach's alpha is provided for boundary spanning breadth and depth measures in this research consistent with Laursen and Salter (2006) and Kostopoulos, et al. (2011) as a measure of internal validity, and both are above the 0.70 threshold. A question for future exploration is whether or not boundary spanning is a formative construct, meaning that the indicators influence the construct (Freeze and Raschke, 2007). If this is indeed that case, high correlation, or reliability, between the indicators would not be expected, required, or a cause for concern since each indicator would be considered and verified as part of the construct (Bollen and Lennox, 1991), thus Cronbach’s alpha may not be the best was to assess validity for this measure. For the purposes of this research, however, the Cronbach’s alpha consistent with extant literature served as a good indicator of internal consistency.

The most widely accepted forms of validity are convergent and discriminant validity (Campbell and Fiske, 1959; Peter, 1981). Convergent validity assesses the degree to which alternative measures of the same concept are associated with high correlations indicating that the measures are indeed measuring the intended concept. In this study, multiple measures were assessed for the dependent variables of firm innovativeness and firm performance. The measures for firm innovativeness demonstrate convergent validity in that a perceptual measure of the construct (from Hurt et al., 1977; Hurt and Teigen, 1977), and an objective measure used in prior studies of the percentage of sales accounted for by new products or services introduced in the 
past three years (from He and Wong, 2004; Manu, 1992; Sidhu et al., 2007) are significantly correlated $(\mathrm{r}=0.28, p=0.05)$.

The convergent validity of firm performance is a bit less straightforward. This study uses the measure of return on sales to operationalize firm performance consistent with prior studies (cf. Sidhu et al., 2007). However, a perceptual scale was also used to measure firm performance (adopted from Pearce II et al., 1987), asking the participant to report how the firm compares to similar firms on the measures of return on assets, return on sales, firm sales growth, and overall firm performance/success. The two measures were not significantly correlated, which raises some question as to the convergent validity of this measure. The return on sales measure had a low response rate and so the correlation may have been significant if more firms had provided a response to this survey question.

Discriminant validity is the degree to which two conceptually similar concepts are distinct (Hair Jr. et al., 2009). To demonstrate that informational, operational, and strategic boundary spanning breadth are indeed discrete constructs, and also differ from absorptive capacity, Table 6 shows the correlations between the measures. These differences provide support for the discriminant validity of the independent and moderating variables. The correlations between informational, operational, and strategic boundary spanning depth and absorptive capacity are also assessed in Table 7 and provide similar evidence of discriminant validity. 
TABLE VI: CORRELATIONS BETEEN BOUNDARY SPANNING BREADTH AND ABSORPITVE CAPACITY

\begin{tabular}{lcccccc}
\hline \multicolumn{1}{c}{ Variables } & Mean & S.D. & $\mathbf{1}$ & $\mathbf{2}$ & $\mathbf{3}$ & $\mathbf{4}$ \\
\hline $\begin{array}{l}\text { Informational boundary spanning } \\
\text { (breadth) }\end{array}$ & 6.19 & 3.55 & 1 & & & \\
$\begin{array}{l}\text { Operational boundary spanning } \\
\text { (breadth) }\end{array}$ & 2.68 & 2.37 & .04 & 1 & & \\
$\begin{array}{l}\text { Strategic boundary spanning } \\
\text { (breadth) }\end{array}$ & 2.93 & 2.19 & .00 & .01 & 1 & \\
Absorptive capacity & 3.73 & .43 & .14 & -.11 & .18 & 1 \\
\hline
\end{tabular}

Correlations shown are not significant at $p<.05$

TABLE VII: CORRELATIONS BETEEN BOUNDARY SPANNING DEPTH AND ABSORPITVE CAPACITY

\begin{tabular}{lcccccc}
\hline \multicolumn{1}{c}{ Variables } & Mean & S.D. & $\mathbf{1}$ & $\mathbf{2}$ & $\mathbf{3}$ & $\mathbf{4}$ \\
\hline $\begin{array}{l}\text { Informational boundary spanning } \\
\text { (depth) }\end{array}$ & 3.16 & 2.74 & 1 & & & \\
$\begin{array}{l}\text { Operational boundary spanning } \\
\text { (depth) }\end{array}$ & 1.68 & 1.59 & .08 & 1 & & \\
$\begin{array}{l}\text { Strategic boundary spanning } \\
\text { (depth) }\end{array}$ & 1.60 & 1.43 & -.01 & .04 & 1 & \\
Absorptive capacity & 3.73 & .43 & .24 & -.03 & .18 & 1 \\
\hline
\end{tabular}

Correlations shown are not significant at $p<.05$ 


\section{ANALYSIS AND RESULTS}

\section{1 $\quad$ Research Procedures and Sample}

Table 8 reports descriptive statistics for the firms in the sample. Of a possible 19 information sources, the mean number used by firms in the sample was quite high, 12.32 sources (s.d.=4.18). The mean number of sources used does not, however, reflect the further categorization of each sources' purpose. As demonstrated by the mean values in Table 8, most firms in the sample indicated that their primary purpose in using many of the sources of information for innovation activities was informational in nature, as opposed to operational or strategic. The firms in the sample reported a mean of $31.6 \%$ of current sales coming from new products or services.

TABLE VIII: VARIABLE DESCRIPTIVE STATISTICS

\begin{tabular}{lccccc}
\hline \multicolumn{1}{c}{ Variable } & $\begin{array}{c}\text { No. of } \\
\text { firms }\end{array}$ & Mean & S.D. & Minimum & Maximum \\
\hline Employees & 48 & 82.48 & 111.40 & 3 & 500 \\
\hline Employees (log) & 48 & 3.50 & 1.51 & 1.10 & 6.21 \\
\hline Firm age & 50 & 20.56 & 16.26 & 1 & 50 \\
Firm age (log) & 50 & 2.50 & 1.25 & 0 & 3.91 \\
\hline Formalization & 51 & 3.03 & 0.97 & 1 & 5 \\
\hline Industry dynamism & 51 & 3.20 & 0.87 & 1.33 & 5 \\
\hline Informational Breadth & 68 & 6.19 & 3.55 & 0 & 14 \\
\hline Informational Depth & 68 & 3.16 & 2.74 & 0 & 13 \\
Operational Breadth & 68 & 2.68 & 2.37 & 0 & 13 \\
\hline Operational Depth & 68 & 1.68 & 1.59 & 0 & 7 \\
Strategic Breadth & 68 & 2.93 & 2.19 & 0 & 8 \\
\hline Strategic Depth & 68 & 1.60 & 1.43 & 0 & 7 \\
\hline Absorptive Capacity & 56 & 3.73 & 0.43 & 2.78 & 4.88 \\
\hline Firm Innovativeness & 48 & 31.60 & 25.61 & 0 & 100 \\
Firm Performance & 23 & 11.39 & 13.08 & 0 & 56 \\
\hline
\end{tabular}


The sample included firms from a variety of industries. The largest concentration of responses came from the Services industry (13 firms), followed by the Manufacturing industry (11 firms). Other represented industries include: Retail, Wholesale (7 firms), Construction (6 firms), Internet (4 firms), Finance, Insurance, Real Estate (4 firms), Health Care (2 firms), Transportation (2 firms), and Communications, Utilities (1 firm).

Table 9 provides the full correlation matrix for the variables included in the research model. 
TABLE IX: CORRELATION MATRIX

\begin{tabular}{|c|c|c|c|c|c|c|c|c|c|c|c|c|c|c|c|c|c|c|c|c|}
\hline Variables & 1 & 2 & 3 & 4 & 5 & 6 & 7 & 8 & 9 & 10 & 11 & 12 & 13 & 14 & 15 & 16 & 17 & 18 & 19 & 20 \\
\hline 1. Employees (log) & 1 & & & & & & & & & & & & & & & & & & & \\
\hline 2. Firm age (log) & $.71^{* *}$ & 1 & & & & & & & & & & & & & & & & & & \\
\hline 3. Formalization & $.34 *$ & .21 & 1 & & & & & & & & & & & & & & & & & \\
\hline 4. Industry dynamism & -.02 & -.12 & .06 & 1 & & & & & & & & & & & & & & & & \\
\hline 5. Finance industry & .06 & .01 & .16 & -.15 & 1 & & & & & & & & & & & & & & & \\
\hline 6. Healthcare industry & -.19 & -.01 & -.13 & -.08 & -.06 & 1 & & & & & & & & & & & & & & \\
\hline 7. Internet industry & $-.41 * *$ & $-.30 *$ & $-.39 * *$ & .19 & -.09 & -.06 & 1 & & & & & & & & & & & & & \\
\hline 8. Manufacturing industry & $.36^{*}$ & $.45^{* *}$ & .05 & -.17 & -.16 & -.11 & -.16 & 1 & & & & & & & & & & & & \\
\hline 9. Retail industry & -.07 & $-.24^{\dagger}$ & -.07 & -.18 & -.12 & -.08 & -.12 & -.21 & 1 & & & & & & & & & & & \\
\hline 10. Services industry & $-.27^{\dagger}$ & $-.29 *$ & -.14 & .15 & -.18 & -.12 & -.18 & $-.32 *$ & $-.24^{\dagger}$ & 1 & & & & & & & & & & \\
\hline 11. Transportation industry & $.26^{\dagger}$ & .17 & $.25^{\dagger}$ & .07 & -.06 & -.04 & -.06 & -.11 & -.08 & -.12 & 1 & & & & & & & & & \\
\hline $\begin{array}{l}\text { 12. Communication } \\
\text { industry }\end{array}$ & .11 & .07 & $.29 *$ & $.30 *$ & -.04 & -.03 & -.04 & -.08 & -.06 & -.09 & -.03 & 1 & & & & & & & & \\
\hline 13. Informational Breadth & .03 & -.16 & .14 & .04 & -.09 & .09 & -.05 & -.04 & .19 & .00 & -.06 & -.17 & 1 & & & & & & & \\
\hline 14. Informational Depth & -.03 & -.18 & .13 & .20 & -.03 & .03 & -.01 & -.09 & -.06 & .11 & -.00 & -.18 & $.74^{* *}$ & 1 & & & & & & \\
\hline 15. Operational Breadth & .23 & .23 & $.26^{\dagger}$ & .00 & -.06 & .18 & -.21 & .03 & -.21 & -.11 & $.35^{*}$ & .06 & .04 & -.01 & 1 & & & & & \\
\hline 16. Operational Depth & .11 & .19 & .20 & .08 & -.09 & .16 & -.19 & .05 & $-.30 *$ & -.03 & .22 & .20 & .03 & .08 & $.85^{* *}$ & 1 & & & & \\
\hline 17. Strategic Breadth & -.05 & .04 & -.09 & .07 & -.17 & .11 & $.34 *$ & .22 & -.19 & -.21 & -.04 & -.07 & .00 & -.09 & .01 & -.05 & 1 & & & \\
\hline 18. Strategic Depth & -.01 & -.02 & -.19 & .22 & -.13 & .06 & $.41^{* *}$ & .19 & -.21 & -.21 & -.09 & .04 & -.01 & -.01 & .04 & .04 & $.66 * *$ & 1 & & \\
\hline 19. Absorptive Capacity & -.00 & .09 & .10 & .05 & -.08 & -.07 & .21 & .09 & -.12 & -.17 & .04 & -.00 & .14 & $.24^{\dagger}$ & -.11 & -.03 & .18 & .18 & 1 & \\
\hline 20. Firm Innovativeness & $-.29^{\dagger}$ & $-.36 *$ & $-.26^{\dagger}$ & $.28^{\dagger}$ & -.18 & .11 & $.35^{*}$ & -.09 & .05 & .02 & -.13 & .17 & .15 & .16 & $-.31^{*}$ & -.17 & $.36^{*}$ & $.40^{* *}$ & $.37^{* *}$ & 1 \\
\hline 21. Firm Performance & -.08 & .07 & -.20 & .05 & - & $.39^{\dagger}$ & -.34 & .02 & -.19 & .24 & - & - & .26 & .02 & -.09 & .06 & -.06 & .04 & -.03 & $.37^{\dagger}$ \\
\hline
\end{tabular}

Cases excluded pairwise: employees (log), $N=48$; firm age (log), $N=50$; formalization and industry dynamism, $N=51$; industry categorizations, $N=50$; boundary spanning breadth and depth measures, $N=68$; absorptive capacity, $N=56$; firm innovativeness, $N=48$; firm performance, $N=23$.

${ }^{\dagger} p<.10 ;{ }^{*} p<.05 ; * * p<.01$ (two-tailed) 


\subsection{Hypothesis Testing}

To test the theoretical model, I applied multiple regression with polynomials and moderated and mediated regression. Power transformations of an independent variable that add a nonlinear component (i.e., the anticipated curvilinear relationship of boundary spanning breadth and depth with firm innovativeness) for each additional power of the independent variable are called “polynomials” (Hair Jr. et al., 2009). Additionally, moderated regression is a relatively conservative way in which to test interaction effects because the interaction term is tested for significance after all lower-order effects have been entered into the regression equation (Jaccard, Wan, and Turrisi, 1990). The moderation effects are only supported if the model, which includes the interaction term, represents a statistically significant improvement over the model with the direct effects (Baron and Kenny, 1986). In the mediated regression, the mediator should account for the relationship between a predictor variable (independent variable) and the criterion (or independent) variable (Baron and Kenny, 1986).

In Hypothesis 1a, I tested if the breadth of boundary spanning activities was, as proposed, curvilinearly (an inverted U-shape) related to firm innovativeness. The curvilinear model with two inflection points (one suggesting diminishing slope of the regression line for breadth of boundary spanning activities and firm innovativeness, with the second inflection point suggesting the relationship turning negative due to oversearch as outlined in Katila and Ahuja (2002)) is modeled with the equation where the variable $\mathrm{X}_{1}$ represents the linear component, the variable squared, $\mathrm{X}_{1}{ }^{2}$, represents the quadratic component, and the variable cubed, $\mathrm{X}_{1}{ }^{3}$, representing the cubic term (Hair Jr. et al., 2009).

$$
\mathrm{Y}=b_{0}+b_{1} \mathrm{X}_{1}+b_{2} \mathrm{X}_{1}^{2}+b_{3} \mathrm{X}_{1}^{3}
$$


where, $b_{0}$ is the intercept, $b_{1} \mathrm{X}_{1}$ represents the linear effect of $\mathrm{X}_{1}$, while $b_{2} \mathrm{X}_{1}{ }^{2}$ and $b_{3} \mathrm{X}_{1}{ }^{3}$ represent the curvilinear effect of $X_{1}$. The control variables of firm size (log), firm age (log), formalization, industry dynamism, and industry were also included in the analysis.

First, a full model was assessed to test the effects of the three forms of boundary spanning breadth on firm innovativeness, and then separate equations were assessed for informational boundary spanning breadth, operational boundary spanning breadth, and strategic boundary spanning breadth. A similar procedure was followed to determine the effect of boundary spanning depth for each of the three boundary spanning objectives on firm innovativeness. Table 10 presents the regression results when predicting firm innovativeness with boundary spanning breadth (Models 1-5).

To reduce potential collinearity, I centered all independent variables before entering them into the regression models. Additionally, consistent with Cohen et al. (2003), I also centered the variables for the interaction terms before conducting the moderation analysis. Following this procedure improves the interpretability of the data without affecting the significance levels of the beta coefficients (Rothaermel and Alexandre, 2009). I estimated the variance inflation factors (VIFs), and found the mean VIF for all direct effects to be 1.08, with a maximum value of 1.14 when estimating operational boundary spanning breadth. This VIF is well below the recommended maximum allowable VIF of 10 (Cohen et al., 2003).

In Hypothesis 1, I proposed that the relationship between a firm's boundary spanning would be curvilinearly (an inverted U-shape) related to firm innovativeness. I first tested the relationships for breadth of boundary spanning. First, a full model of breadth of boundary spanning for all three objectives together was tested with firm innovativeness (Model 2 in Table 10). While the full model was significantly different $(p<0.05)$ from the model with only the 


\section{TABLE X: EFFECTS OF BOUNDARY SPANNING BREADTH ON FIRM INNOVATIVENESS}

\begin{tabular}{|c|c|c|c|c|c|}
\hline \multicolumn{6}{|c|}{ Firm Innovativeness } \\
\hline & Model 1 & Model 2 & Model 3 & Model 4 & Model 5 \\
\hline \multicolumn{6}{|l|}{ Independent Variables } \\
\hline \multicolumn{6}{|l|}{ Main effects } \\
\hline Informational breadth & & .24 & .23 & & \\
\hline Operational breadth & & -.13 & & -.25 & \\
\hline Strategic breadth & & $.37 *$ & & & $.36 *$ \\
\hline \multicolumn{6}{|l|}{ Covariates } \\
\hline Firm size (log) & .11 & .02 & .04 & .12 & .09 \\
\hline Firm age (log) & $-.39^{\dagger}$ & -.32 & -.36 & $-.40^{\dagger}$ & -.35 \\
\hline Formalization & -.06 & -.16 & -.10 & -.03 & -.14 \\
\hline Industry dynamism & .08 & .02 & .04 & .08 & .07 \\
\hline Finance industry & -.05 & .02 & -.06 & -.12 & .06 \\
\hline Healthcare industry & .20 & .11 & .13 & .21 & .18 \\
\hline Internet industry & .32 & .13 & .27 & .24 & .22 \\
\hline Manufacturing industry & .21 & .12 & .17 & .14 & .20 \\
\hline Retail industry & .00 & -.06 & -.09 & -.09 & .09 \\
\hline Services industry & .10 & .12 & .06 & .01 & .21 \\
\hline Transportation industry & -.01 & .09 & .00 & .03 & .05 \\
\hline Communications industry & .23 & $.35^{*}$ & $.29^{\dagger}$ & .21 & .30 \\
\hline \multicolumn{6}{|l|}{ Explained Variance } \\
\hline F value & 1.39 & $1.96^{\dagger}$ & 1.50 & 1.49 & 1.84 \\
\hline $\mathrm{R}^{2}$ (Adjusted $\mathrm{R}^{2}$ ) & $.34(.10)$ & $.50(.25)$ & $.39(.13)$ & $.39(.13)$ & $.44(.20)$ \\
\hline$\Delta \mathrm{R}^{2}\left(\Delta\right.$ Adjusted $\mathrm{R}^{2}$ ) & & $.16(.15)$ & $.04(.03)$ & $.04(.03)$ & $.09(.10)$ \\
\hline F Change & & $.04 *$ & 2.18 & 2.11 & $5.06^{*}$ \\
\hline
\end{tabular}


covariates (Model 1 in Table 10), only strategic boundary spanning breadth was significant in the underlying model; thus, the three objectives were tested separately in Models 3 through 5 in Table 10 to parse out the effects of the individual objectives. In the individual regression analyses of breadth of informational, operational, and strategic boundary spanning activities, only strategic boundary spanning breadth was found to have a significant relationship with firm innovativeness $(p<0.05)$.

To test for the curvilinearity of the regression lines, I squared the breadth terms and entered them into the separate regression equations. This was done for the informational, operational, and strategic boundary spanning breadth measures. The results showed the quadratic equations were not significant, suggesting that the relationship between breadth of boundary spanning for informational, operational, and strategic boundary spanning and firm innovativeness is linear, rather than curvilinear. With the absence of a significant relationship between breadth of informational and operational boundary spanning and firm innovativeness, and only a significant linear relationship between breadth of strategic boundary spanning and firm innovativeness, Hypothesis 1a is not supported.

The second part of Hypothesis 1 (Hypothesis 1b) tested for a curvilinear relationship (an inverted U-shape) between the depth of a firm’s boundary spanning and firm innovativeness. The analysis was conducted similarly to that used to test Hypothesis 1a, but depth of informational, operational, and strategic boundary spanning was used in place of the breadth measures. As outlined in the measures section, boundary spanning depth represents the degree to which a firm relies on boundary spanning activities to drive innovation activities through interactions with information sources. If firms use an information source to a moderate or high degree, they are considered to have a deep relationship with that information source, and 
boundary spanning depth is the sum total of the number of deep boundary spanning activities that the firm engages in. I first regressed the full model of depth of all three boundary spanning objectives with firm innovativeness, and found it was not significantly different from the covariate only model (see Model 2 in Table 11). I then regressed each objective’s boundary spanning depth measure with firm innovativeness separately (see Models 3-5 in Table 11) and found only depth of strategic boundary spanning to be marginally significant $(p<0.10)$.

I then squared the depth measures for informational, operational, and strategic boundary spanning and entered them into the respective regression equations. None of the squared terms were significant, and thus, the relationship between depth of boundary spanning and firm innovativeness is likely linear, and not curvilinear, as hypothesized. Hypothesis $1 \mathrm{~b}$ is not supported.

Contrary to expectations, the relationship between each of the boundary spanning objectives and firm innovativeness is linear, and then only significant for the objective of strategic boundary spanning breadth and depth (marginally). The other boundary spanning objectives of informational and operational boundary spanning did not show a significant relationship with firm innovativeness for breadth or depth at all. Due to the absence of a curvilinear relationship between breadth and depth of boundary spanning for each objective, Hypotheses 2a and 2b are no longer testable. Further, since only strategic boundary spanning for both breadth and depth were significantly related to firm innovativeness, there is no way to test these hypotheses with the linear relationships alone. Thus, Hypotheses $2 \mathrm{a}$ and $2 \mathrm{~b}$ are not supported.

The question of whether or not an interaction effect exists between boundary spanning activities and absorptive capacity was also assessed in accordance with Hypothesis 3 . The 


\section{TABLE XI: EFFECTS OF BOUNDARY SPANNING DEPTH ON FIRM INNOVATIVENESS}

\begin{tabular}{|c|c|c|c|c|c|}
\hline \multicolumn{6}{|c|}{ Firm Innovativeness } \\
\hline & Model 1 & Model 2 & Model 3 & Model 4 & Model 5 \\
\hline \multicolumn{6}{|l|}{ Independent Variables } \\
\hline \multicolumn{6}{|l|}{ Main effects } \\
\hline Informational depth & & .13 & .17 & & \\
\hline Operational depth & & -.07 & & -.10 & \\
\hline Strategic depth & & .29 & & & $.32^{\dagger}$ \\
\hline \multicolumn{6}{|l|}{ Covariates } \\
\hline Firm size (log) & .11 & .01 & .08 & .09 & .04 \\
\hline Firm age (log) & $-.39^{\dagger}$ & -.30 & $-.39^{\dagger}$ & $-.38^{\dagger}$ & -.30 \\
\hline Formalization & -.06 & -.07 & -.07 & -.06 & -.06 \\
\hline Industry dynamism & .08 & -.01 & .04 & .09 & .02 \\
\hline Finance industry & -.05 & -.03 & -.07 & -.08 & .01 \\
\hline Healthcare industry & .20 & .16 & .17 & .20 & .19 \\
\hline Internet industry & .32 & .20 & .30 & .28 & .24 \\
\hline Manufacturing industry & .21 & .16 & .19 & .18 & .18 \\
\hline Retail industry & .00 & .05 & .02 & -.04 & .07 \\
\hline Services industry & .10 & .14 & .07 & .07 & .20 \\
\hline Transportation industry & -.01 & .04 & -.02 & .00 & .05 \\
\hline Communications industry & .23 & $.30^{\dagger}$ & .28 & .24 & .25 \\
\hline \multicolumn{6}{|l|}{ Explained Variance } \\
\hline F value & 1.39 & 1.43 & 1.37 & 1.29 & 1.65 \\
\hline $\mathrm{R}^{2}$ (Adjusted $\mathrm{R}^{2}$ ) & $.34(.10)$ & $.43(.13)$ & $.37(.10)$ & $.35(.08)$ & $.41(.16)$ \\
\hline$\Delta \mathrm{R}^{2}\left(\Delta\right.$ Adjusted $\mathrm{R}^{2}$ ) & & $.08(.03)$ & $.02(.00)$ & $.01(.02)$ & $.07(.06)$ \\
\hline F Change & & 1.38 & 1.07 & .38 & $3.45^{\dagger}$ \\
\hline
\end{tabular}


hypothesis was only analyzed for the two significant independent variables of breadth and depth of strategic boundary spanning. This hypothesis suggests that the positive effect of a firm's breadth and depth of boundary spanning on firm innovativeness will be stronger when the firm possesses higher levels of absorptive capacity. To test this hypothesis, both independent variables (breadth and depth of strategic boundary spanning), as well as the absorptive capacity variable, were centered to reduce unessential overlaps between the interaction term and the lower order effects. The main effect of breadth of strategic boundary spanning and firm innovativeness was assessed previously and found to be positive and significant, with breadth of strategic boundary spanning accounting for approximately $20 \%$ of the variance in firm innovativeness. Depth of strategic boundary spanning was also regressed with firm innovativeness and found to be significant, accounting for $16 \%$ of the variance.

The interaction of breadth of strategic boundary spanning and absorptive capacity was regressed with firm innovativeness, including the control variables (firm age (log), firm size (log), formalization, industry dynamism, and industry). The interaction was not significant, meaning that absorptive capacity does not moderate the relationship between breadth of strategic boundary spanning and firm innovativeness. The analysis was repeated for the interaction of depth of strategic boundary spanning and absorptive capacity, and again, the interaction term was not significant. See Table 12 for detailed results of the analyses. Hypothesis 3 is not supported. 


\section{TABLE XII: INTERACTION EFFECT OF ABSORPTIVE CAPACITY BETWEEN BREADTH AND DEPTH OF STRATEGIC BOUNDARY SPANNING AND FIRM INNOVATIVENESS}

\begin{tabular}{llcc}
\hline \multicolumn{4}{c}{ FIRM INNOVATIVENESS } \\
\hline & Model 1 & Model 2 & Model 3 \\
\hline Independent Variables & & & \\
Main effects & & & \\
\hline Strategic breadth & & $.31^{\dagger}$ & \\
\hline Strategic depth & & .27 \\
\hline Interaction Effects & & & \\
\hline Strategic breadth x ACAP & & .11 & \\
\hline Strategic depth x ACAP & & & .18 \\
\hline Covariates & & & \\
\hline Firm size (log) & .11 & .09 & .06 \\
\hline Firm age (log) & $-.39^{\dagger}$ & -.33 & -.29 \\
\hline Formalization & -.06 & -.16 & -.08 \\
\hline Industry dynamism & .08 & .07 & .01 \\
\hline Finance industry & -.05 & .06 & .01 \\
\hline Healthcare industry & .20 & .20 & .20 \\
\hline Internet industry & .32 & .21 & .22 \\
\hline Manufacturing industry & .21 & .22 & .18 \\
\hline Retail industry & .00 & .10 & .07 \\
\hline Services industry & .10 & .23 & .22 \\
\hline Transportation industry & -.01 & $.06^{\dagger}$ & .05 \\
\hline Communications industry & .23 & $.31^{\dagger}$ & .27 \\
\hline Explained Variance & & & \\
\hline F value & 1.39 & 1.71 & 1.65 \\
\hline $\mathrm{R}^{2}$ (Adjusted $\mathrm{R}^{2}$ ) & $.34(.10)$ & $.44(.18)$ & $.44(.17)$ \\
\hline$\Delta \mathrm{R}^{2}$ ( $\Delta$ Adjusted $\mathrm{R}^{2}$ ) & & $.01(-.02)$ & $.03(.01)$ \\
\hline F Change & & .43 & 1.07 \\
\hline & & & \\
\hline
\end{tabular}

Note: Independent and interaction variables were mean-centered. Model 1 is the baseline model where only covariates are included. Models 2-3 are to test interaction effects. ${ }^{\dagger} p \leq .10 ; *^{*} p \leq .05 ; \mathrm{N}=45$ 
Lastly, Hypothesis 4 states that firm innovativeness is positively related to firm performance. Mediated regression was used to assess the full model's relationship between boundary spanning breadth and depth with firm performance, as well as the direct relationship between firm innovativeness and firm performance. Baron and Kenny (1986) propose a four step approach to mediated regression where four regression analyses are conducted and the significance of the coefficient is examined at each step. For the first three steps, or analyses, direct effects must exist between the independent and mediating variables, as well as between the independent and the mediating variable with the dependent variable. If one or more of these relationships are found to be nonsignificant, mediation is not possible, or at a minimum not likely (Baron and Kenny, 1986).

Given that there is no significant relationship between breadth or depth of informational or operational boundary spanning and firm innovativeness, the mediation effect with firm performance is not interpretable. However, it is interesting to note that breadth of informational boundary spanning has a positive and significant $(p<0.05)$ direct relationship with firm performance. Depth of informational boundary spanning, as well as breadth and depth of operational boundary spanning do not have a significant relationship with firm performance. Strategic boundary spanning breadth and depth both have a significant relationship with firm innovativeness, albeit the relationship between depth of strategic boundary spanning and firm innovativeness is not a strong one. The relationship between breadth of strategic boundary spanning and firm performance, however, is not significant. A significant relationship between depth of strategic boundary spanning and firm performance is also lacking. Thus, firm innovativeness does not mediate the relationship between boundary spanning and firm performance. See Table 13 for detailed results of these analyses. 
The direct relationship between firm innovativeness and firm performance, as suggested in Hypothesis 4, is supported as a standalone interpretation (not taking into account boundary spanning breadth or depth). This finding should be interpreted cautiously, however, due to the low sample size for cases with available data to assess this relationship, and the lack of a strong tie to the rest of the research model. 


\section{TABLE XIII: MEDIATED REGRESSION ANALYSIS BETWEEN BOUNDARY SPANNING AND FIRM PERFORMANCE}

\begin{tabular}{|c|c|c|c|c|c|c|c|}
\hline \multicolumn{8}{|c|}{ Firm Performance } \\
\hline & Model 1 & Model 2 & Model 3 & Model 4 & Model 5 & Model 6 & Model 7 \\
\hline \multicolumn{8}{|l|}{ Independent Variables } \\
\hline \multicolumn{8}{|l|}{ Main effects } \\
\hline Informational breadth & $1.05^{*}$ & & & & & & \\
\hline Operational breadth & & -.43 & & & & & \\
\hline Strategic breadth & & & .06 & & & & \\
\hline Informational depth & & & & -.19 & & & \\
\hline Operational depth & & & & & -.33 & & \\
\hline Strategic depth & & & & & & .02 & \\
\hline Firm innovativeness & & & & & & & $.73^{*}$ \\
\hline \multicolumn{8}{|l|}{ Covariates } \\
\hline Firm size (log) & $-1.14^{*}$ & -.07 & -.13 & -.06 & -.11 & -.16 & -.21 \\
\hline Firm age (log) & .18 & -.28 & -.27 & -.42 & -.31 & -.26 & .31 \\
\hline Formalization & .02 & -.20 & -.17 & -.19 & -.22 & -.14 & -.19 \\
\hline Industry dynamism & $-.62^{\dagger}$ & .13 & .19 & .34 & .18 & .18 & .15 \\
\hline Healthcare industry & -.00 & .31 & .31 & .33 & .36 & .30 & .10 \\
\hline Internet industry & $-.68^{\dagger}$ & $-.91^{\dagger}$ & -.70 & -.79 & $-.88^{\dagger}$ & -.69 & $-.80 *$ \\
\hline Manufacturing industry & -.20 & -.08 & .12 & .18 & .03 & .11 & -.05 \\
\hline Retail industry & -.27 & -.38 & -.10 & -.14 & -.31 & -.12 & -.17 \\
\hline Services industry & .05 & -.30 & .03 & -.06 & -.23 & .01 & .01 \\
\hline \multicolumn{8}{|l|}{ Explained Variance } \\
\hline F value & 2.51 & 1.10 & .79 & .82 & .95 & .79 & 2.14 \\
\hline $\mathrm{R}^{2}$ (Adjusted $\mathrm{R}^{2}$ ) & $.72(.43)$ & $.53(.05)$ & $.44(-.12)$ & $.45(-.10)$ & $.49(-.03)$ & $.44(-.12)$ & $.68(.36)$ \\
\hline$\Delta \mathrm{R}^{2}\left(\Delta\right.$ Adjusted $\mathrm{R}^{2}$ ) & $.28(.45)$ & $.09(.07)$ & $.00(-.10)$ & $.01(-.08)$ & $.05(-.01)$ & $.00(-.10)$ & $.24(.38)$ \\
\hline F Change & $9.65^{*}$ & 1.78 & .03 & .18 & .92 & .01 & $7.58^{*}$ \\
\hline
\end{tabular}

Note: Independent variables were mean-centered. Full mediated model could not be tested due to lack of significance in some of the underlying regressions required to proceed with the full mediated regression. ${ }^{\dagger} p \leq .10 ;{ }^{*} p \leq .05 ; \mathrm{N}=21$ 


\section{DISCUSSION}

More and more in the entrepreneurship literature, models of firms drawing information from external sources to drive innovation activities are replacing Schumpeter's model of the lone entrepreneur bringing innovations to the market (Laursen and Salter, 2006; Schumpeter, 1976;

Szulanski, 1996; Von Hippel, 1988). To begin to understand the relevance of the objectives with which firms search for information from external sources, this study examined the role of informational, operational, and strategic boundary spanning objectives in shaping firm innovativeness. To do this, I sought to contribute to the boundary spanning literature by linking information search processes to the outcomes of innovation and performance for the firm. Specifically, I introduced three categories of boundary spanning, called boundary spanning objectives: informational boundary spanning, operational boundary spanning, and strategic boundary spanning, to better articulate the intentions with which firms search for external information.

I argued that firm innovativeness would benefit from both a greater breadth and depth of each form of boundary spanning. However, I predicted that, at a point, the firm would see diminishing returns for their efforts, eventually becoming a negative relationship between breadth and depth of boundary spanning and firm innovativeness. This set of relationships suggested that too much time devoted to boundary spanning would ultimately harm firm innovativeness. The predicted relationship was consistent with Katila and Ahuja's finding that “over-searching” may hinder innovation performance (Katila and Ahuja, 2002). The results of this study, however, found only a linear (not curvilinear, as “over-searching” would suggest) relationship between breadth and depth of boundary spanning activities, and even then, only for strategic boundary spanning. 
The lack of significance of the relationship between both breadth and depth of informational and operational boundary spanning and firm innovativeness is interesting because it suggests that gathering general industry, market, or product information to stay abreast of trends or new developments, as well as gathering specific information for current use in innovating or improving the day-to-day operations of the firm, do not, at least directly, influence firm innovativeness. This is not to say that these forms of boundary spanning activities do not add value within the firm, but perhaps that they do not contribute to the realization of firm innovations directly, as is the case for strategic boundary spanning activities.

Breadth of informational boundary spanning did have a positive and significant relationship with firm performance, suggesting that the value of having a broad number of information sources for the purposes of innovation may still add value to the firm's bottom line, even though they do not contribute directly to the level of innovation within the firm. An alternative argument for why a positive relationship may exist between informational boundary spanning and firm performance may be that firms with strong performance are more likely to have the resources to encourage broader informational boundary spanning by its employees.

Gathering specific information for an intended future use in innovating or improving the strategic direction of the firm - the definition that was provided for strategic boundary spanning - was found to drive firm innovativeness. The higher the number of unique information sources which the firm engages with for the primary purpose of accomplishing strategic innovation activities (breadth), the higher the innovativeness of the firm. Relatedly, having a deep relationship with the information sources that the firm relies on to drive strategic innovation (depth) also leads to greater firm innovativeness. 
While the relationship between breadth and depth of strategic boundary spanning and firm innovativeness was not curvilinear, as hypothesized, this empirical finding is actually more promising for entrepreneurial firms. Simply put, the more boundary spanning a firm engages in with the intent of innovating or improving the strategic direction of the firm, the better. This finding is consistent with the recent meta-analysis by Rosenbusch, et al. (2011) that found entrepreneurial firms to benefit significantly more from a strategic innovation orientation than from a more general innovation focus on just developing new products or services. An additional explanation may be that entrepreneurial firms do not have the resources to reach a point at which their breadth and/or depth of boundary spanning would begin to have diminishing returns for firm innovativeness.

In this study, absorptive capacity did not moderate the relationship between strategic boundary spanning activities and firm innovativeness as hypothesized. Absorptive capacity research has previously identified the existence of firms that focus excessively on searching for external knowledge, without a corresponding emphasis on exploiting that acquired knowledge (Zahra and George, 2002). The broad measure for absorptive capacity used in this study (from Lichtenthaler, 2009), takes into account the degree to which the firms in the sample were successful in exploiting the knowledge gained through boundary spanning activities. This concept of knowledge exploitation, or transformation, captured in Lichtenthaler's (2009) scale has its foundation in prior research on "realized absorptive capacity" from Zahra and George (2002), and Jansen, et al. (2005). The findings of the empirical analysis in this study may be a reflection of the informational and operational boundary spanning not being successfully exploited for the purpose of driving innovation within the firm. In a post-hoc analysis of the direct relationship between absorptive capacity and firm innovativeness of the firms included in 
the sample, the relationship is positive and significant (r-squared $=0.36, p<0.01)$. The lack of significance for the moderation effect of absorptive capacity on the direct effect between strategic boundary spanning breadth (depth) and firm innovativeness may suggest that while the firm's ability to identify and value external knowledge (Cohen and Levinthal, 1990; Cohen and Levinthal, 1994) is important for driving firm innovativeness, strategic boundary spanning independently achieves firm innovativeness, rather than complimentarily.

Firm innovativeness was found to have a positive, significant relationship with firm performance; however, the sample size of usable cases for this relationship was so small (21 cases with responses to both variables), that the result must be interpreted with caution. The more subjective measure of firm performance was not significant with firm innovativeness, and thus further raises questions about the true nature of the relationship between these two variables. These findings are not unique - as mentioned previously, empirical research on the innovationperformance relationship in entrepreneurial firms has shown controversial results (Rosenbusch et al., 2011). Firm age, type of innovation, and cultural context can all affect the impact of innovation on firm performance (Rosenbusch et al., 2011). While this study controls for firm age, type innovation is not addressed (cultural context is somewhat controlled for in that all of the firms were U.S.-based).

The findings are consistent with the important theoretical link between boundary spanning and the innovation process (Aldrich and Herker, 1977; Tushman, 1977; Utterback, 1971). There are also interesting new linkages which extend Hult’s (2011) MOR theory. Firstly, Hult (2011) specifically emphasizes the importance of directing the resources of the marketing organization toward developing a strategic position in the market. The finding that strategic boundary spanning is a driver of firm innovativeness in the entrepreneurial firm supports this 
focus, and contributes to the theory by demonstrating that it is not just the resources of the marketing organization that should be devoted to achieving a strategic position, but for the firm as a whole to have this as a priority.

The second key strength area of MOR theory emphasizes the need for the marketing organization to develop procedures for managing the large amounts of information available to marketing leaders, enabling them to better understand the external environment (Hult, 2011). In this study, breadth of informational boundary spanning was found to have a positive and significant relationship with firm performance. This suggests that by better managing the information entrepreneurial firms may be acquiring from the different information sources, they could positively influence firm performance. This could also strengthen the relationship between breadth of information boundary spanning and firm innovativeness by making the information gathered more organized, and perhaps more easily transformed into future innovations for the firm to develop. This could be a direction for future research.

While this research does not contribute significantly to the MOR theory’s strength area of network alliances and collaborations, the results of this study suggest that the theory should carefully examine the marketplace operations strength area (Hult, 2011). Hult (2011) asserts that marketing organizations have to operate in internal and external networks to support the needs of stakeholders and market influences, suggesting deep relationships between these groups. This research finds that strong relationships exist between the breadth of strategic boundary spanning and firm innovativeness, and the breadth of informational boundary spanning and firm performance. Depth of strategic boundary spanning was marginally significant with firm innovativeness. Thus, while it may be important to interact with a broad group of external 
stakeholders, the diversity of interactions may be more important than the depth of the interactions when seeking to influence firm innovativeness and firm performance.

From an organizational learning standpoint, the findings support the theory in that learning is found to be conducive to a firm's successful performance (Zahra, 2012) (i.e., how breadth of informational boundary spanning was found to drive a firm’s return on sales as a measure of firm performance). The boundary spanning objectives that were introduced provided support for the tenant of organizational learning theory which says firms engage in many different types of searches for information (Katila, 2002; Von Hippel and Tyre, 1995), and contributes to the literature by providing some specific ways in which firms pursue these searches. Further, breadth and depth of strategic boundary spanning was found to be the most important type of search for information for the purpose of driving innovation activities.

\subsection{Limitations and Future Research}

The results of this research must be interpreted with consideration of the data collection limitations. Data measuring both the independent and the dependent variables were collected at the same time. This is a significant drawback of cross-sectional data in that it is not possible to test for a cause and effect relationship between entrepreneurial boundary spanning and firm innovativeness and firm performance. The results of the hypotheses must, therefore, be interpreted as providing findings that should be further explored with the dependent variable coming from a secondary data source, or alternatively, measured at a time separate from that of the independent variables.

A major limitation of this research is the small sample size. Some of the potential relationships depicted in the research model may become significant with a larger data set of 
entrepreneurial firms. Additionally, surveying corporations to have the ability to analyze differences between the two samples would also provide a stronger basis of what is truly unique to entrepreneurial firms. On a positive note, participants indicated whether or not the firm was considered a family business, as well as a woman- or minority-owned business. These distinctions could provide for interesting analyses on differences between these firms in terms of boundary spanning, firm innovativeness, and firm performance in the future.

In terms of the analysis of breadth and depth of the three forms of boundary spanning, much of the original variance is lost between the initial recording of the data (low, medium, or high degree of reliance on the information source) and the computation of the dummy variables used to assess breadth and depth in the research model. While the method of analysis used in this study is consistent with prior research looking at breadth and depth of external information sources (e.g. Kostopoulos et al., 2011; Laursen and Salter, 2006), other forms of analysis should be explored to take advantage of the full variance in the boundary spanning measure.

In conducting future research on boundary spanning objectives, providing a broader list of information sources may help to allay any concerns related to restriction of range in terms of the number and scope of the list of information sources provided. While 19 information sources was a thorough list based on prior literature and adapted to include a few additional Internetbased sources, more could be ascertained through an exploratory study where qualitative data on firm boundary spanning was collected and assessed. It could be that a point of diminishing returns, and perhaps even a second inflection point, could be identified if the point at which over search emerges is past the range of this study (past the mark of 19 information sources).

The lack of a significant relationship between the depth and breadth of informational and operational boundary spanning and firm innovativeness leaves opportunities for future research 
on why these boundary spanning objectives do not contribute directly to the innovation process. Perhaps by taking a step back and pursuing a more qualitative, or mixed methods, approach to determining the ways in which entrepreneurial firms integrate the information acquired through informational or operational boundary spanning into their innovation process, a more appropriate mechanism could be uncovered.

While extant research has explored the complexity of the relationship between firm innovativeness and firm performance in entrepreneurial firms, this research demonstrates that the inconsistencies may require further study and analysis. Perhaps there is an intervening variable between the two constructs that would help to explain this relationship with more confidence.

The ties between external search and innovation have become so intertwined that Subramaniam and Youndt (2005) have likened it to a blurring of boundaries between the two areas. One of the aims of this research is to better define the boundary spanning construct, taking into account the effect of the objective with which entrepreneurial firms engage in external search to drive firm innovativeness and performance. While the findings of this research were not conclusive across the different boundary spanning objectives, they lay the groundwork for future research on further delineating these constructs. 


\section{APPENDIX}

UNIVERSITY OF ILLINOIS

AT CHICAGO

Office for the Protection of Research Subjects (OPRS)

Office of the Vice Chancellor for Research (MC 672)

203 Administrative Office Building

1737 West Polk Street

Chicago, Illinois 60612-7227

\section{Request for Modification and/or Information \\ Initial Review - Claim of Exemption}

July 20, 2012

\section{*20120606- 69016-1*}

20120606-69016-1

Laurel Ofstein, BA, MBA

Managerial Studies

University Hall

601 S Morgan St, M/C 243

Chicago, IL 60607

Phone: (312) 933-9410 / Fax: (312) 996-3559

RE: Research Protocol \# 2012-0606

"Boundary Spanning in the Entrepreneurial Firm: Effects on Innovation and Firm Performance"

Dear Ms. Ofstein:

Your request for a Claim of Exemption to your research protocol was reviewed on July 20, 2012. It was determined that the following is required: 
1. Please revise the "Sample Request to Entrepreneur Networking Organization, Request for Permission to Distribute Survey to Members” letter to indicate the survey will take 20-25 minutes to complete.

Please note the Review History of this submission:

\begin{tabular}{|l|l|l|l|l|}
\hline Receipt Date & Submission Type & Review Process & Review Date & Review Action \\
\hline $07 / 16 / 2012$ & Initial Review & Exempt & $07 / 20 / 2012$ & Modifications Required \\
\hline
\end{tabular}

When submitting your response provide 1 original and 2 copies ( 3 packets total) of the following collated materials:

1. A cover letter that references this letter and that responds item by item to each specific issue listing the IRB's requirements from that letter followed by your response. Please use the same numbering system as in the IRB's letter.

2. A copy of this letter so that the bar code on the letter can be scanned.

3. For modifications that involve the research protocol and/or research protocol application:

a. Provide the revised research protocol, and/or research protocol application with the modifications and information incorporated.

b. Please highlight or shade the additions and strike through the deletions on each of the three (3) copies.

c. Include the next sequential version number and date on each page.

4. For modifications that involve questionnaires, survey instruments, interview questions, data collection instruments, consent documents and/or recruitment materials:

a. Provide one original and two (2) copies of each revised item.

b. On two (2) copies, please highlight or shade the additions and strike through the deletions.

c. Include a short descriptor (to describe each document and differentiate among various documents in the same research protocol) in the footer of each page.

d. Include the next sequential version number and date in the footer of each page.

e. Be sure the pages are numbered: Page 1 of \#, Page 2 of \#.

It has been determined that your response to these required modifications may be reviewed under exempt review procedures. Based on your response, the OPRS has the authority to ask further questions, seek additional information, require further modifications, or refer the research for IRB review. 
Please note that you may not implement your research until you receive a written notice of IRB approval.

If you do not respond to the IRB's request within 90 days of this letter, the submission may be withdrawn from the review process and the IRB will not take any further action.

If you have any questions or need further help, please contact the OPRS office at (312) 996-1711 or me at (312) 355-2908. Please send any correspondence about this protocol to OPRS at 203 AOB, M/C 672.

Sincerely,

Charles W. Hoehne, B.S., C.I.P.

Assistant Director, IRB \# 2

Office for the Protection of Research Subjects

Enclosure(s): None

cc: Mark Shanley, Managerial Studies, M/C 243 
UNIVERSITY OF ILLINOIS

AT CHICAGO

Office for the Protection of Research Subjects (OPRS)

Office of the Vice Chancellor for Research (MC 672)

203 Administrative Office Building

1737 West Polk Street

Chicago, Illinois 60612-7227

\section{Exemption Granted}

August 2, 2012

Laurel Ofstein, BA, MBA

Managerial Studies

University Hall

601 S Morgan St, M/C 243

Chicago, IL 60607

Phone: (312) 933-9410 / Fax: (312) 996-3559

RE: $\quad$ Research Protocol \# 2012-0606

"Boundary Spanning in the Entrepreneurial Firm: Effects on Innovation and Firm Performance”

\section{Sponsor: None}

\section{Dear Ms. Ofstein:}

Your Claim of Exemption was reviewed on August 2, 2012 and it was determined that you research meets the criteria for exemption. You may now begin your research.

Exemption Period: $\quad$ August 2, 2012 - August 2, 2015

Performance Site: UIC

Subject Population: $\quad$ Adult (18+ years) subjects only

Number of Subjects: $\quad 350$ 


\section{The specific exemption category under 45 CFR 46.101(b) is:}

(2) Research involving the use of educational tests (cognitive, diagnostic, aptitude, achievement), survey procedures, interview procedures or observation of public behavior, unless: (i) information obtained is recorded in such a manner that human subjects can be identified, directly or through identifiers linked to the subjects; and (ii) any disclosure of the human subjects' responses outside the research could reasonably place the subjects at risk of criminal or civil liability or be damaging to the subjects' financial standing, employability, or reputation.

\section{Please note the Review History of this submission:}

\begin{tabular}{|l|l|l|l|l|}
\hline Receipt Date & Submission Type & Review Process & Review Date & Review Action \\
\hline $07 / 16 / 2012$ & Initial Review & Exempt & $07 / 20 / 2012$ & Modifications Required \\
\hline $07 / 25 / 2012$ & Response to Modifications & Exempt & $08 / 02 / 2012$ & Approved \\
\hline
\end{tabular}

You are reminded that investigators whose research involving human subjects is determined to be exempt from the federal regulations for the protection of human subjects still have responsibilities for the ethical conduct of the research under state law and UIC policy. Please be aware of the following UIC policies and responsibilities for investigators:

1. Amendments You are responsible for reporting any amendments to your research protocol that may affect the determination of the exemption and may result in your research no longer being eligible for the exemption that has been granted.

2. Record Keeping You are responsible for maintaining a copy all research related records in a secure location in the event future verification is necessary, at a minimum these documents include: the research protocol, the claim of exemption application, all questionnaires, survey instruments, interview questions and/or data collection instruments associated with this research protocol, recruiting or advertising materials, any consent forms or information sheets given to subjects, or any other pertinent documents.

3. Final Report When you have completed work on your research protocol, you should submit a final report to the Office for Protection of Research Subjects (OPRS).

4. Information for Human Subjects UIC Policy requires investigators to provide information about the research protocol to subjects and to obtain their permission prior to their participating in the research. The information about the research protocol should be presented to subjects in writing or orally from a written script. When appropriate, the following information must be provided to all research subjects participating in exempt studies: 
a. The researchers affiliation; UIC, JBVMAC or other institutions,

b. The purpose of the research,

c. The extent of the subject's involvement and an explanation of the procedures to be followed,

d. Whether the information being collected will be used for any purposes other than the proposed research,

e. A description of the procedures to protect the privacy of subjects and the confidentiality of the research information and data,

f. Description of any reasonable foreseeable risks,

g. Description of anticipated benefit,

h. A statement that participation is voluntary and subjects can refuse to participate or can stop at any time,

i. A statement that the researcher is available to answer any questions that the subject may have and which includes the name and phone number of the investigator(s).

j. A statement that the UIC IRB/OPRS or JBVMAC Patient Advocate Office is available if there are questions about subject's rights, which includes the appropriate phone numbers.

Please be sure to:

$\rightarrow$ Use your research protocol number (2012-0606) on any documents or correspondence with the IRB concerning your research protocol.

We wish you the best as you conduct your research. If you have any questions or need further help, please contact the OPRS office at (312) 996-1711 or me at (312) 355-2908. Please send any correspondence about this protocol to OPRS at 203 AOB, M/C 672.

Sincerely,

Charles W. Hoehne, B.S.

Assistant Director, IRB \# 2

Office for the Protection of Research Subjects

cc: Mark Shanley, Managerial Studies, M/C 243 


\section{Survey (online version administered through Qualtrics): \\ University of Illinois at Chicago \\ Consent for Participation Research}

\section{Entrepreneurial Activities Survey}

Thank you for participating in this research study. The purpose of this study is to better understand entrepreneurial activities and their effects on innovation and performance in entrepreneurial firms. If you agree to participate, please complete the following survey. It will take 20-25 minutes.

All responses collected will be used for academic research purposes only, and only aggregate statistics will be reported. Your participation is strictly confidential. No information will be shared that might reveal the identities of you, your product(s), or your firm. Your name and contact information will not be associated with this study in any way. Your participation is voluntary. You are free to withdraw from this study at any time without penalty. There are no known physical, psychological, social, or economic risks or benefits to you for participating in the survey.

If you have any questions, please contact Laurel Ofstein at the University of Illinois at Chicago at: (312)933-9410 or by email at lofste2@uic.edu.

Also, if you have any questions about your rights as a research participant, you may contact the Office for the Protection of Research Subjects (OPRS), University of Illinois at Chicago, at (312)996-1711 (local) or (866)789-6215 (toll-free) or e-mail OPRS at uicirb@uic.edu.

I have read the above information and I agree to participate in this research.

Yes

No

Signature:

Date:

Printed Name: 
The following questions will ask you to provide answers about the activities of your firm and its employees. If you have founded, and/or currently work for, multiple firms, please answer the questions about your primary employer or current firm.

\begin{tabular}{|l|c|}
\hline 1. Are you the founder of this firm? & $\square \quad$ Yes \\
\cline { 2 - 2 } & $\square \quad$ No \\
\hline
\end{tabular}

\begin{tabular}{|l|c|}
\hline $\begin{array}{l}\text { 2. Are you actively involved in strategic } \\
\text { decision making within this firm? }\end{array}$ & $\square \quad$ Yes \\
\cline { 2 - 3 } & $\square$ No \\
\hline
\end{tabular}

3. What is your job title?

\begin{tabular}{|l|c|}
\hline 4. Is this a woman-owned firm? & $\square \quad$ Yes \\
\cline { 2 - 3 } & $\square$ No \\
\hline
\end{tabular}

\begin{tabular}{|l|c|}
\hline 5. Is this a minority-owned firm? & $\square \quad$ Yes \\
\cline { 2 - 3 } & $\square$ No \\
\hline
\end{tabular}

A family business can be defined as an enterprise in which 2 or more family members own $15 \%$ or more of the shares, family members are employed in the business, and the family intends to retain control of the firm in the future.

\begin{tabular}{|l|c|}
\hline 6. Is this a family business? & $\square \quad$ Yes \\
\cline { 2 - 3 } & $\square$ No \\
\hline
\end{tabular}


Innovation, or innovation activities, can be defined as developing a new product or service idea, a new process technology, a new business model, a new organization form, and so on.

\begin{tabular}{|l|c|c|c|c|}
\cline { 2 - 4 } \multicolumn{1}{c|}{} & Not at all & $\begin{array}{c}\text { Low } \\
\text { Degree }\end{array}$ & $\begin{array}{c}\text { Moderate } \\
\text { Degree }\end{array}$ & High Degree \\
\hline $\begin{array}{l}\text { 7. To what degree is your firm } \\
\text { participating in innovation } \\
\text { activities? }\end{array}$ & 0 & 1 & 2 & 3 \\
\hline
\end{tabular}

Innovation activities may include developing a new product or service idea, a new process technology, a new business model, a new organization form, and so on.

8. To what degree does your firm rely on each of these sources of information for its innovation activities?

\begin{tabular}{|l|c|c|c|c|}
\cline { 2 - 5 } \multicolumn{1}{l|}{} & Not Used & Low & Medium & High \\
\hline Clients or customers & 0 & 1 & 2 & 3 \\
\hline $\begin{array}{l}\text { Suppliers of equipment, materials, } \\
\text { components, or software }\end{array}$ & 0 & 1 & 2 & 3 \\
\hline Competitors & 0 & 1 & 2 & 3 \\
\hline Consultants & 0 & 1 & 2 & 3 \\
\hline $\begin{array}{l}\text { Commercial laboratories / Research and } \\
\text { Development (R\&D) enterprises }\end{array}$ & 0 & 1 & 2 & 3 \\
\hline $\begin{array}{l}\text { Universities or other higher education } \\
\text { institutions }\end{array}$ & 0 & 1 & 2 & 3 \\
\hline Government research organizations & 0 & 1 & 2 & 3 \\
\hline $\begin{array}{l}\text { Other public sector organizations (such } \\
\text { as government offices or small business } \\
\text { development centers) }\end{array}$ & 0 & 1 & 2 & 2 \\
\hline Private research institutions & 0 & 1 & & 3 \\
\hline Trade associations & 0 & 1 & 2 & 3 \\
\hline Employees of your own firm & & & & 3 \\
\hline
\end{tabular}


Innovation activities may include developing a new product or service idea, a new process technology, a new business model, a new organization form, and so on.

9. To what degree does your firm rely on each of these sources of information for its innovation activities?

\begin{tabular}{|l|c|c|c|c|}
\cline { 2 - 4 } \multicolumn{1}{l|}{} & Not Used & Low & Medium & High \\
\hline Professional conferences, meetings & 0 & 1 & 2 & 3 \\
\hline $\begin{array}{l}\text { Technical / Trade press, computer } \\
\text { databases }\end{array}$ & 0 & 1 & 2 & 3 \\
\hline Trade fairs, exhibitions & 0 & 1 & 2 & 3 \\
\hline Technical standards & 0 & 1 & 2 & 3 \\
\hline Health and safety standards & 0 & 1 & 2 & 3 \\
\hline Environmental standards and regulations & 0 & 1 & 2 & 3 \\
\hline $\begin{array}{l}\text { Social media (such as Twitter, } \\
\text { Facebook, LinkedIn, blogs) }\end{array}$ & 0 & 1 & 2 & 2 \\
\hline General Internet searches & 0 & 1 & & \\
\hline
\end{tabular}

10. Please list up to three additional sources of information your firm relies on for innovation activities, if any.

1.

2.

3. 
11. For each of the information sources you use for innovation, please select its primary, and if applicable, secondary purpose for your firm's innovation activities.

Informational: Gathering general industry, market, or product information to stay abreast of trends or new developments.

Operational: Gathering specific information for current use in innovating or improving the day-to-day operations of the firm. This may include ways to better serve existing customers, to better manage inbound and/or outbound logistics, or to improve financial management activities.

Strateqic: Gathering specific information for an intended future use in innovating or improving the strategic direction of the firm.

(Please Note: Please indicate a primary purpose for each information source you rely on from questions 8 and 9 above. The firm may or may not have a secondary, or any other, purpose and these can be left blank if only one purpose is applicable.)

\begin{tabular}{|c|c|c|c|}
\hline & Primary purpose & Secondary purpose & $\begin{array}{l}\text { Any other } \\
\text { purpose }\end{array}$ \\
\hline Clients or customers & $\begin{array}{l}\square \text { Informational } \\
\square \text { Operational } \\
\square \text { Strategic }\end{array}$ & $\begin{array}{l}\square \text { Informational } \\
\square \text { Operational } \\
\square \text { Strategic }\end{array}$ & $\begin{array}{l}\square \text { Informational } \\
\square \text { Operational } \\
\square \text { Strategic }\end{array}$ \\
\hline $\begin{array}{l}\text { Suppliers of equipment, materials, } \\
\text { components, or software }\end{array}$ & $\begin{array}{l}\square \text { Informational } \\
\square \text { Operational } \\
\square \text { Strategic }\end{array}$ & $\begin{array}{l}\square \text { Informational } \\
\square \text { Operational } \\
\square \text { Strategic }\end{array}$ & $\begin{array}{l}\square \text { Informational } \\
\square \text { Operational } \\
\square \text { Strategic }\end{array}$ \\
\hline Competitors & $\begin{array}{l}\square \text { Informational } \\
\square \text { Operational } \\
\square \text { Strategic }\end{array}$ & $\begin{array}{l}\square \text { Informational } \\
\square \text { Operational } \\
\square \text { Strategic }\end{array}$ & $\begin{array}{l}\square \text { Informational } \\
\square \text { Operational } \\
\square \text { Strategic }\end{array}$ \\
\hline Consultants & $\begin{array}{l}\square \text { Informational } \\
\square \text { Operational } \\
\square \text { Strategic }\end{array}$ & $\begin{array}{l}\square \text { Informational } \\
\square \text { Operational } \\
\square \text { Strategic }\end{array}$ & $\begin{array}{l}\square \text { Informational } \\
\square \text { Operational } \\
\square \text { Strategic }\end{array}$ \\
\hline $\begin{array}{l}\text { Commercial laboratories / Research } \\
\text { and Development (R\&D) enterprises }\end{array}$ & $\begin{array}{l}\square \text { Informational } \\
\square \text { Operational } \\
\square \text { Strategic }\end{array}$ & $\begin{array}{l}\square \text { Informational } \\
\square \text { Operational } \\
\square \text { Strategic }\end{array}$ & $\begin{array}{l}\square \text { Informational } \\
\square \text { Operational } \\
\square \text { Strategic }\end{array}$ \\
\hline $\begin{array}{l}\text { Universities or other higher education } \\
\text { institutions }\end{array}$ & $\begin{array}{l}\square \text { Informational } \\
\square \text { Operational } \\
\square \text { Strategic }\end{array}$ & $\begin{array}{l}\square \text { Informational } \\
\square \text { Operational } \\
\square \text { Strategic }\end{array}$ & $\begin{array}{l}\square \text { Informational } \\
\square \text { Operational } \\
\square \text { Strategic }\end{array}$ \\
\hline
\end{tabular}


Informational: Gathering general industry, market, or product information to stay abreast of trends or new developments.

Operational: Gathering specific information for current use in innovating or improving the day-to-day operations of the firm. This may include ways to better serve existing customers, to better manage inbound and/or outbound logistics, or to improve financial management activities.

Strateqic: Gathering specific information for an intended future use in innovating or improving the strategic direction of the firm.

(Please Note: Please indicate a primary purpose for each information source you rely on from questions 8 and 9 above. The firm may or may not have a secondary, or any other, purpose and these can be left blank if only one purpose is applicable.)

\begin{tabular}{|c|c|c|c|}
\hline & Primary purpose & Secondary purpose & $\begin{array}{l}\text { Any other } \\
\text { purpose }\end{array}$ \\
\hline Government research organizations & $\begin{array}{l}\square \text { Informational } \\
\square \text { Operational } \\
\square \text { Strategic }\end{array}$ & $\begin{array}{l}\square \text { Informational } \\
\square \text { Operational } \\
\square \text { Strategic }\end{array}$ & $\begin{array}{l}\square \text { Informational } \\
\square \text { Operational } \\
\square \text { Strategic }\end{array}$ \\
\hline $\begin{array}{l}\text { Other public sector organizations } \\
\text { (such as government offices or small } \\
\text { business development centers) }\end{array}$ & $\begin{array}{l}\square \text { Informational } \\
\square \text { Operational } \\
\square \text { Strategic }\end{array}$ & $\begin{array}{l}\square \text { Informational } \\
\square \text { Operational } \\
\square \text { Strategic }\end{array}$ & $\begin{array}{l}\square \text { Informational } \\
\square \text { Operational } \\
\square \text { Strategic }\end{array}$ \\
\hline Private research institutions & $\begin{array}{l}\square \text { Informational } \\
\square \text { Operational } \\
\square \text { Strategic }\end{array}$ & $\begin{array}{l}\square \text { Informational } \\
\square \text { Operational } \\
\square \text { Strategic }\end{array}$ & $\begin{array}{l}\square \text { Informational } \\
\square \text { Operational } \\
\square \text { Strategic }\end{array}$ \\
\hline Trade associations & $\begin{array}{l}\square \text { Informational } \\
\square \text { Operational } \\
\square \text { Strategic }\end{array}$ & $\begin{array}{l}\square \text { Informational } \\
\square \text { Operational } \\
\square \text { Strategic }\end{array}$ & $\begin{array}{l}\square \text { Informational } \\
\square \text { Operational } \\
\square \text { Strategic }\end{array}$ \\
\hline Employees of your own firm & $\begin{array}{l}\square \text { Informational } \\
\square \text { Operational } \\
\square \text { Strategic }\end{array}$ & $\begin{array}{l}\square \text { Informational } \\
\square \text { Operational } \\
\square \text { Strategic }\end{array}$ & $\begin{array}{l}\square \text { Informational } \\
\square \text { Operational } \\
\square \text { Strategic }\end{array}$ \\
\hline Professional conferences, meetings & $\begin{array}{l}\square \text { Informational } \\
\square \text { Operational } \\
\square \text { Strategic }\end{array}$ & $\begin{array}{l}\square \text { Informational } \\
\square \text { Operational } \\
\square \text { Strategic }\end{array}$ & $\begin{array}{l}\square \text { Informational } \\
\square \text { Operational } \\
\square \text { Strategic }\end{array}$ \\
\hline $\begin{array}{l}\text { Technical / Trade press, computer } \\
\text { databases }\end{array}$ & $\begin{array}{l}\square \text { Informational } \\
\square \text { Operational } \\
\square \text { Strategic }\end{array}$ & $\begin{array}{l}\square \text { Informational } \\
\square \text { Operational } \\
\square \text { Strategic }\end{array}$ & $\begin{array}{l}\square \text { Informational } \\
\square \text { Operational } \\
\square \text { Strategic }\end{array}$ \\
\hline
\end{tabular}


Informational: Gathering general industry, market, or product information to stay abreast of trends or new developments.

Operational: Gathering specific information for current use in innovating or improving the day-to-day operations of the firm. This may include ways to better serve existing customers, to better manage inbound and/or outbound logistics, or to improve financial management activities.

Strateqic: Gathering specific information for an intended future use in innovating or improving the strategic direction of the firm.

(Please Note: Please indicate a primary purpose for each information source you rely on from questions 8 and 9 above. The firm may or may not have a secondary, or any other, purpose and these can be left blank if only one purpose is applicable.)

\begin{tabular}{|c|c|c|c|}
\hline & Primary purpose & Secondary purpose & $\begin{array}{l}\text { Any other } \\
\text { purpose }\end{array}$ \\
\hline Trade fairs, exhibitions & $\begin{array}{l}\square \text { Informational } \\
\square \text { Operational } \\
\square \text { Strategic }\end{array}$ & $\begin{array}{l}\square \text { Informational } \\
\square \text { Operational } \\
\square \text { Strategic }\end{array}$ & $\begin{array}{l}\square \text { Informational } \\
\square \text { Operational } \\
\square \text { Strategic }\end{array}$ \\
\hline Technical standards & $\begin{array}{l}\square \text { Informational } \\
\square \text { Operational } \\
\square \text { Strategic }\end{array}$ & $\begin{array}{l}\square \text { Informational } \\
\square \text { Operational } \\
\square \text { Strategic }\end{array}$ & $\begin{array}{l}\square \text { Informational } \\
\square \text { Operational } \\
\square \text { Strategic }\end{array}$ \\
\hline Health and safety standards & $\begin{array}{l}\square \text { Informational } \\
\square \text { Operational } \\
\square \text { Strategic }\end{array}$ & $\begin{array}{l}\square \text { Informational } \\
\square \text { Operational } \\
\square \text { Strategic }\end{array}$ & $\begin{array}{l}\square \text { Informational } \\
\square \text { Operational } \\
\square \text { Strategic }\end{array}$ \\
\hline $\begin{array}{l}\text { Environmental standards and } \\
\text { regulations }\end{array}$ & $\begin{array}{l}\square \text { Informational } \\
\square \text { Operational } \\
\square \text { Strategic }\end{array}$ & $\begin{array}{l}\square \text { Informational } \\
\square \text { Operational } \\
\square \text { Strategic }\end{array}$ & $\begin{array}{l}\square \text { Informational } \\
\square \text { Operational } \\
\square \text { Strategic }\end{array}$ \\
\hline $\begin{array}{l}\text { Social media (such as Twitter, } \\
\text { Facebook, LinkedIn, blogs) }\end{array}$ & $\begin{array}{l}\square \text { Informational } \\
\square \text { Operational } \\
\square \text { Strategic }\end{array}$ & $\begin{array}{l}\square \text { Informational } \\
\square \text { Operational } \\
\square \text { Strategic }\end{array}$ & $\begin{array}{l}\square \text { Informational } \\
\square \text { Operational } \\
\square \text { Strategic }\end{array}$ \\
\hline General Internet searches & $\begin{array}{l}\square \text { Informational } \\
\square \text { Operational } \\
\square \text { Strategic }\end{array}$ & $\begin{array}{l}\square \text { Informational } \\
\square \text { Operational } \\
\square \text { Strategic }\end{array}$ & $\begin{array}{l}\square \text { Informational } \\
\square \text { Operational } \\
\square \text { Strategic }\end{array}$ \\
\hline
\end{tabular}


Informational: Gathering general industry, market, or product information to stay abreast of trends or new developments.

Operational: Gathering specific information for current use in innovating or improving the day-to-day operations of the firm. This may include ways to better serve existing customers, to better manage inbound and/or outbound logistics, or to improve financial management activities.

Strateqic: Gathering specific information for an intended future use in innovating or improving the strategic direction of the firm.

(Please Note: Please indicate a primary purpose for each information source you rely on from questions 8 and 9 above. The firm may or may not have a secondary, or any other, purpose and these can be left blank if only one purpose is applicable.)

\begin{tabular}{|l|l|l|l|}
\cline { 2 - 4 } \multicolumn{1}{c|}{} & Primary purpose & Secondary purpose & \multicolumn{1}{|c|}{$\begin{array}{c}\text { Any other } \\
\text { purpose }\end{array}$} \\
\hline $\begin{array}{l}\text { Additional Source 1 } \\
\text { (from question 10, if applicable) }\end{array}$ & $\begin{array}{l}\square \text { Informational } \\
\square \text { Operational } \\
\square \text { Strategic }\end{array}$ & $\begin{array}{l}\square \text { Informational } \\
\square \text { Operational } \\
\square \text { Strategic }\end{array}$ & $\begin{array}{l}\square \text { Informational } \\
\square \text { Operational } \\
\square \text { Strategic }\end{array}$ \\
\hline $\begin{array}{l}\text { Additional Source 2 } \\
\text { (from question 10, if applicable) }\end{array}$ & $\begin{array}{l}\square \text { Informational } \\
\square \text { Operational } \\
\square \text { Strategic }\end{array}$ & $\begin{array}{l}\square \text { Informational } \\
\square \text { Operational } \\
\square \text { Strategic }\end{array}$ & $\begin{array}{l}\square \text { Informational } \\
\square \text { Operational } \\
\square \text { Strategic }\end{array}$ \\
\hline $\begin{array}{l}\text { Additional Source 3 } \\
\text { (from question 10, if applicable) }\end{array}$ & $\begin{array}{l}\square \text { Informational } \\
\square \text { Operational } \\
\square \text { Strategic }\end{array}$ & $\begin{array}{l}\square \text { Informational } \\
\square \text { Operational } \\
\square \text { Strategic }\end{array}$ & $\begin{array}{l}\square \text { Informational } \\
\square \text { Operational } \\
\square \text { Strategic }\end{array}$ \\
\hline
\end{tabular}

12. On average, what percentage of your individual work time is spent searching for information to drive innovation activities?

\begin{tabular}{|l|c|}
\hline $\begin{array}{l}\text { Inside the firm (for example, research and } \\
\text { development, employee ideas) }\end{array}$ & \% \\
\hline $\begin{array}{l}\text { Outside the firm (for example, clients or } \\
\text { customers, universities) }\end{array}$ & $\%$ \\
\hline
\end{tabular}


13. Please list the job titles of up to three additional employees, other than yourself, who participate in the innovation activities listed in the previous four pages (if applicable).

(Please Note: This question is intended for research purposes only. The individuals associated with the job titles provided will NOT be contacted.)

1.

On average, what percentage of his/her work time is spent searching for information to drive innovation activities?

\begin{tabular}{|l|c|}
\hline $\begin{array}{l}\text { Inside the firm (for example, research and } \\
\text { development, employee ideas) }\end{array}$ & \\
\hline $\begin{array}{l}\text { Outside the firm (for example, clients or } \\
\text { customers, universities) }\end{array}$ & $\%$ \\
\hline
\end{tabular}

2.

On average, what percentage of his/her work time is spent searching for information to drive innovation activities?

\begin{tabular}{|l|c|}
\hline $\begin{array}{l}\text { Inside the firm (for example, research and } \\
\text { development, employee ideas) }\end{array}$ & \\
\hline $\begin{array}{l}\text { Outside the firm (for example, clients or } \\
\text { customers, universities) }\end{array}$ & $\%$ \\
\hline
\end{tabular}

3.

On average, what percentage of his/her work time is spent searching for information to drive innovation activities?

\begin{tabular}{|l|c|}
\hline $\begin{array}{l}\text { Inside the firm (for example, research and } \\
\text { development, employee ideas) }\end{array}$ \\
\hline $\begin{array}{l}\text { Outside the firm (for example, clients or } \\
\text { customers, universities) }\end{array}$ & $\%$ \\
\hline
\end{tabular}


14. To what degree do you agree with the following statements about your firm?

\begin{tabular}{|l|c|c|c|c|c|}
\cline { 2 - 5 } \multicolumn{1}{l|}{} & $\begin{array}{c}\text { Strongly } \\
\text { Disagree }\end{array}$ & Disagree & $\begin{array}{c}\text { Neither Agree } \\
\text { nor Disagree }\end{array}$ & Agree & $\begin{array}{c}\text { Strongly } \\
\text { Agree }\end{array}$ \\
\hline $\begin{array}{l}\text { The firm frequently tries out } \\
\text { new ideas. }\end{array}$ & 1 & 2 & 3 & 4 & 5 \\
\hline $\begin{array}{l}\text { The firm seeks out new ways to } \\
\text { do things. }\end{array}$ & 1 & 2 & 3 & 4 & 5 \\
\hline $\begin{array}{l}\text { The firm is creative in its } \\
\text { methods of operation. }\end{array}$ & 1 & 2 & 3 & 4 & 5 \\
\hline $\begin{array}{l}\text { The firm is often the first to } \\
\text { market with new products and } \\
\text { services. }\end{array}$ & 1 & 2 & 3 & 4 & 5 \\
\hline $\begin{array}{l}\text { Innovation in this firm is } \\
\text { perceived as too risky and is } \\
\text { resisted. }\end{array}$ & 1 & 2 & 3 & 4 & 5 \\
\hline $\begin{array}{l}\text { The firm's new product / service } \\
\text { introductions have increased } \\
\text { over the last 3 years. }\end{array}$ & & & & & \\
\hline
\end{tabular}


15. To what degree do you agree with the following statements about your firm?

\begin{tabular}{|l|c|c|c|c|c|}
\cline { 2 - 5 } \multicolumn{1}{l|}{} & $\begin{array}{c}\text { Strongly } \\
\text { Disagree }\end{array}$ & Disagree & $\begin{array}{c}\text { Neither Agree } \\
\text { nor Disagree }\end{array}$ & Agree & $\begin{array}{c}\text { Strongly } \\
\text { Agree }\end{array}$ \\
\hline $\begin{array}{l}\text { We frequently scan the } \\
\text { environment for new product / } \\
\text { service ideas. }\end{array}$ & 1 & 2 & 3 & 4 & 5 \\
\hline $\begin{array}{l}\text { We thoroughly observe } \\
\text { technological / market trends. }\end{array}$ & 1 & 2 & 3 & 4 & 5 \\
\hline $\begin{array}{l}\text { We observe in detail external } \\
\text { sources of technology or service } \\
\text { innovations. }\end{array}$ & 1 & 2 & 3 & 4 & 5 \\
\hline $\begin{array}{l}\text { We thoroughly collect industry } \\
\text { information. }\end{array}$ & 1 & 2 & 3 & 4 & 5 \\
\hline $\begin{array}{l}\text { We have information on the } \\
\text { state-of-the-art of external } \\
\text { technology or service } \\
\text { innovations. }\end{array}$ & 1 & 2 & 3 & 4 & 5 \\
\hline
\end{tabular}


16. To what degree do you agree with the following statements about your firm?

\begin{tabular}{|l|c|c|c|c|c|}
\hline & $\begin{array}{c}\text { Strongly } \\
\text { Disagree }\end{array}$ & Disagree & $\begin{array}{c}\text { Neither Agree } \\
\text { nor Disagree }\end{array}$ & Agree & $\begin{array}{c}\text { Strongly } \\
\text { Agree }\end{array}$ \\
\hline $\begin{array}{l}\text { We frequently acquire product / } \\
\text { service innovations from } \\
\text { external sources. }\end{array}$ & 1 & 2 & 3 & 4 & 5 \\
\hline $\begin{array}{l}\text { We periodically organize special } \\
\text { meetings with external partners } \\
\text { to acquire technology or service } \\
\text { innovations. }\end{array}$ & 1 & 2 & 3 & 4 & 5 \\
\hline $\begin{array}{l}\text { Employees regularly approach } \\
\text { external institutions to acquire } \\
\text { product / service knowledge. }\end{array}$ & 1 & 2 & 3 & 4 & 5 \\
\hline $\begin{array}{l}\text { We often transfer new } \\
\text { knowledge to our firm in } \\
\text { response to product / service } \\
\text { acquisition opportunities. }\end{array}$ & 1 & 2 & 3 & 4 & 5 \\
\hline
\end{tabular}


17. To what degree do you agree with the following statements about your firm?

\begin{tabular}{|l|c|c|c|c|c|}
\cline { 2 - 6 } \multicolumn{1}{l|}{} & $\begin{array}{c}\text { Strongly } \\
\text { Disagree }\end{array}$ & Disagree & $\begin{array}{c}\text { Neither Agree } \\
\text { nor Disagree }\end{array}$ & Agree & $\begin{array}{c}\text { Strongly } \\
\text { Agree }\end{array}$ \\
\hline $\begin{array}{l}\text { We thoroughly maintain } \\
\text { relevant knowledge over time. }\end{array}$ & 1 & 2 & 3 & 4 & 5 \\
\hline $\begin{array}{l}\text { Employees store product / } \\
\text { service knowledge for future } \\
\text { reference. }\end{array}$ & 1 & 2 & 3 & 4 & 5 \\
\hline $\begin{array}{l}\text { We communicate relevant } \\
\text { knowledge across the units of } \\
\text { our firm. }\end{array}$ & 1 & 2 & 3 & 4 & 5 \\
\hline $\begin{array}{l}\text { Knowledge management is } \\
\text { functioning well in our firm. }\end{array}$ & 1 & 2 & 3 & 4 & 5 \\
\hline $\begin{array}{l}\text { When recognizing a business } \\
\text { opportunity, we can quickly rely } \\
\text { on our existing knowledge. }\end{array}$ & 1 & 2 & 3 & 4 & 5 \\
\hline $\begin{array}{l}\text { We are proficient in applying } \\
\text { existing knowledge to new uses. }\end{array}$ & 1 & 2 & 3 & 4 & 5 \\
\hline $\begin{array}{l}\text { We quickly analyze and } \\
\text { interpret changing market } \\
\text { demands for our products / } \\
\text { services. }\end{array}$ & 1 & 2 & 3 & 4 & 5 \\
\hline $\begin{array}{l}\text { New opportunities to serve our } \\
\text { customers with existing products } \\
\text { / services are quickly } \\
\text { understood. }\end{array}$ & 1 & 2 & 3 & 4 & 5 \\
\hline
\end{tabular}


18. To what degree do you agree with the following statements about your firm?

\begin{tabular}{|c|c|c|c|c|c|}
\hline & $\begin{array}{l}\text { Strongly } \\
\text { Disagree }\end{array}$ & Disagree & $\begin{array}{c}\text { Neither Agree } \\
\text { nor Disagree }\end{array}$ & Agree & $\begin{array}{c}\text { Strongly } \\
\text { Agree }\end{array}$ \\
\hline $\begin{array}{l}\text { We are proficient in } \\
\text { transforming knowledge into } \\
\text { new products / services. }\end{array}$ & 1 & 2 & 3 & 4 & 5 \\
\hline $\begin{array}{l}\text { We regularly match new } \\
\text { technological or service } \\
\text { innovations with ideas for new } \\
\text { products or services. }\end{array}$ & 1 & 2 & 3 & 4 & 5 \\
\hline $\begin{array}{l}\text { We quickly recognize the } \\
\text { usefulness of new knowledge } \\
\text { for existing products / services. }\end{array}$ & 1 & 2 & 3 & 4 & 5 \\
\hline $\begin{array}{l}\text { Our employees are capable of } \\
\text { sharing their expertise to } \\
\text { develop new products or } \\
\text { services. }\end{array}$ & 1 & 2 & 3 & 4 & 5 \\
\hline $\begin{array}{l}\text { We regularly apply technology } \\
\text { or service innovations in new } \\
\text { products or services. }\end{array}$ & 1 & 2 & 3 & 4 & 5 \\
\hline $\begin{array}{l}\text { We constantly consider how to } \\
\text { better exploit new technology or } \\
\text { service innovations. }\end{array}$ & 1 & 2 & 3 & 4 & 5 \\
\hline $\begin{array}{l}\text { We easily implement technology } \\
\text { or service innovations in new } \\
\text { products or services. }\end{array}$ & 1 & 2 & 3 & 4 & 5 \\
\hline $\begin{array}{l}\text { It is well known who can best } \\
\text { exploit new technology or } \\
\text { service innovations inside our } \\
\text { firm. }\end{array}$ & 1 & 2 & 3 & 4 & 5 \\
\hline
\end{tabular}


19. For each of the applicable information sources listed below, think of one organization for each source that your firm interacts with the most for innovation activities. If not applicable, leave that row blank.

Please rate the degree to which the following statements describe your firm's relationship with your most important...

\begin{tabular}{|c|c|c|c|}
\hline & $\begin{array}{l}\text { We feel indebted to this } \\
\text { organization for what } \\
\text { they have done for us. }\end{array}$ & $\begin{array}{c}\text { Our interactions with } \\
\text { this organization can } \\
\text { be defined as } \\
\text { "mutually gratifying." }\end{array}$ & $\begin{array}{l}\text { Maintaining a long- } \\
\text { term relationship } \\
\text { with this } \\
\text { organization is } \\
\text { important to us. }\end{array}$ \\
\hline Client or customer & $\begin{array}{l}\square \text { Strongly agree } \\
\square \text { Agree } \\
\square \text { Neither agree nor } \\
\quad \text { disagree } \\
\square \text { Disagree } \\
\square \text { Strongly disagree }\end{array}$ & $\begin{array}{l}\square \text { Strongly agree } \\
\square \text { Agree } \\
\square \text { Neither agree nor } \\
\quad \text { disagree } \\
\square \text { Disagree } \\
\square \text { Strongly disagree }\end{array}$ & $\begin{array}{l}\square \text { Strongly agree } \\
\square \text { Agree } \\
\square \text { Neither agree nor } \\
\quad \text { disagree } \\
\square \text { Disagree } \\
\square \text { Strongly disagree }\end{array}$ \\
\hline $\begin{array}{l}\text { Supplier of equipment, } \\
\text { materials, components, or } \\
\text { software }\end{array}$ & $\begin{array}{l}\square \text { Strongly agree } \\
\square \text { Agree } \\
\square \text { Neither agree nor } \\
\text { disagree } \\
\square \text { Disagree } \\
\square \text { Strongly disagree }\end{array}$ & $\begin{array}{l}\square \text { Strongly agree } \\
\square \text { Agree } \\
\square \text { Neither agree nor } \\
\quad \text { disagree } \\
\square \text { Disagree } \\
\square \text { Strongly disagree }\end{array}$ & $\begin{array}{l}\square \text { Strongly agree } \\
\square \text { Agree } \\
\square \text { Neither agree nor } \\
\text { disagree } \\
\square \text { Disagree } \\
\square \text { Strongly disagree }\end{array}$ \\
\hline Competitor & $\begin{array}{l}\square \text { Strongly agree } \\
\square \text { Agree } \\
\square \text { Neither agree nor } \\
\text { disagree } \\
\square \text { Disagree } \\
\square \text { Strongly disagree }\end{array}$ & $\begin{array}{l}\square \text { Strongly agree } \\
\square \text { Agree } \\
\square \text { Neither agree nor } \\
\text { disagree } \\
\square \text { Disagree } \\
\square \text { Strongly disagree }\end{array}$ & $\begin{array}{l}\square \text { Strongly agree } \\
\square \text { Agree } \\
\square \text { Neither agree nor } \\
\text { disagree } \\
\square \text { Disagree } \\
\square \text { Strongly disagree }\end{array}$ \\
\hline Consultant & $\begin{array}{l}\square \text { Strongly agree } \\
\square \text { Agree } \\
\square \text { Neither agree nor } \\
\text { disagree } \\
\square \text { Disagree } \\
\square \text { Strongly disagree }\end{array}$ & $\begin{array}{l}\square \text { Strongly agree } \\
\square \text { Agree } \\
\square \text { Neither agree nor } \\
\text { disagree } \\
\square \text { Disagree } \\
\square \text { Strongly disagree }\end{array}$ & $\begin{array}{l}\square \text { Strongly agree } \\
\square \text { Agree } \\
\square \text { Neither agree nor } \\
\text { disagree } \\
\square \text { Disagree } \\
\square \text { Strongly disagree }\end{array}$ \\
\hline $\begin{array}{l}\text { Commercial laboratory / } \\
\text { Research and Development } \\
\text { enterprise }\end{array}$ & $\begin{array}{l}\square \text { Strongly agree } \\
\square \text { Agree } \\
\square \text { Neither agree nor } \\
\text { disagree } \\
\square \text { Disagree } \\
\square \text { Strongly disagree }\end{array}$ & $\begin{array}{l}\square \text { Strongly agree } \\
\square \text { Agree } \\
\square \text { Neither agree nor } \\
\text { disagree } \\
\square \text { Disagree } \\
\square \text { Strongly disagree }\end{array}$ & $\begin{array}{l}\square \text { Strongly agree } \\
\square \text { Agree } \\
\square \text { Neither agree nor } \\
\text { disagree } \\
\square \text { Disagree } \\
\square \text { Strongly disagree }\end{array}$ \\
\hline
\end{tabular}


For each of the applicable information sources listed below, think of one organization for each source that your firm interacts with the most for innovation activities. If not applicable, leave that row blank.

Please rate the degree to which the following statements describe your firm's relationship with your most important...

\begin{tabular}{|c|c|c|c|}
\hline & $\begin{array}{l}\text { We feel indebted to this } \\
\text { organization for what } \\
\text { they have done for us. }\end{array}$ & $\begin{array}{c}\text { Our interactions with } \\
\text { this organization can } \\
\text { be defined as } \\
\text { "mutually gratifying." }\end{array}$ & $\begin{array}{c}\text { Maintaining a long- } \\
\text { term relationship } \\
\text { with this } \\
\text { organization is } \\
\text { important to us. }\end{array}$ \\
\hline $\begin{array}{l}\text { University or other higher } \\
\text { education institution }\end{array}$ & $\begin{array}{l}\square \text { Strongly agree } \\
\square \text { Agree } \\
\square \text { Neither agree nor } \\
\text { disagree } \\
\square \text { Disagree } \\
\square \text { Strongly disagree }\end{array}$ & $\begin{array}{l}\square \text { Strongly agree } \\
\square \text { Agree } \\
\square \text { Neither agree nor } \\
\quad \text { disagree } \\
\square \text { Disagree } \\
\square \text { Strongly disagree }\end{array}$ & $\begin{array}{l}\square \text { Strongly agree } \\
\square \text { Agree } \\
\square \text { Neither agree nor } \\
\text { disagree } \\
\square \text { Disagree } \\
\square \text { Strongly disagree }\end{array}$ \\
\hline $\begin{array}{l}\text { Government research } \\
\text { organization }\end{array}$ & $\begin{array}{l}\square \text { Strongly agree } \\
\square \text { Agree } \\
\square \text { Neither agree nor } \\
\text { disagree } \\
\square \text { Disagree } \\
\square \text { Strongly disagree }\end{array}$ & $\begin{array}{l}\square \text { Strongly agree } \\
\square \text { Agree } \\
\square \text { Neither agree nor } \\
\text { disagree } \\
\square \text { Disagree } \\
\square \text { Strongly disagree }\end{array}$ & $\begin{array}{l}\square \text { Strongly agree } \\
\square \text { Agree } \\
\square \text { Neither agree nor } \\
\text { disagree } \\
\square \text { Disagree } \\
\square \text { Strongly disagree }\end{array}$ \\
\hline $\begin{array}{l}\text { Other public sector } \\
\text { organization (such as } \\
\text { government office or small } \\
\text { business development center) }\end{array}$ & $\begin{array}{l}\square \text { Strongly agree } \\
\square \text { Agree } \\
\square \text { Neither agree nor } \\
\text { disagree } \\
\square \text { Disagree } \\
\square \text { Strongly disagree }\end{array}$ & $\begin{array}{l}\square \text { Strongly agree } \\
\square \text { Agree } \\
\square \text { Neither agree nor } \\
\text { disagree } \\
\square \text { Disagree } \\
\square \text { Strongly disagree }\end{array}$ & $\begin{array}{l}\square \text { Strongly agree } \\
\square \text { Agree } \\
\square \text { Neither agree nor } \\
\text { disagree } \\
\square \text { Disagree } \\
\square \text { Strongly disagree }\end{array}$ \\
\hline Private research institution & $\begin{array}{l}\square \text { Strongly agree } \\
\square \text { Agree } \\
\square \text { Neither agree nor } \\
\text { disagree } \\
\square \text { Disagree } \\
\square \text { Strongly disagree }\end{array}$ & $\begin{array}{l}\square \text { Strongly agree } \\
\square \text { Agree } \\
\square \text { Neither agree nor } \\
\text { disagree } \\
\square \text { Disagree } \\
\square \text { Strongly disagree }\end{array}$ & $\begin{array}{l}\square \text { Strongly agree } \\
\square \text { Agree } \\
\square \text { Neither agree nor } \\
\text { disagree } \\
\square \text { Disagree } \\
\square \text { Strongly disagree }\end{array}$ \\
\hline Trade association & $\begin{array}{l}\square \text { Strongly agree } \\
\square \text { Agree } \\
\square \text { Neither agree nor } \\
\text { disagree } \\
\square \text { Disagree } \\
\square \text { Strongly disagree }\end{array}$ & $\begin{array}{l}\square \text { Strongly agree } \\
\square \text { Agree } \\
\square \text { Neither agree nor } \\
\text { disagree } \\
\square \text { Disagree } \\
\square \text { Strongly disagree }\end{array}$ & $\begin{array}{l}\square \text { Strongly agree } \\
\square \text { Agree } \\
\square \text { Neither agree nor } \\
\text { disagree } \\
\square \text { Disagree } \\
\square \text { Strongly disagree }\end{array}$ \\
\hline
\end{tabular}


20. Continuing on from the previous question, for each of the applicable information sources listed below, think of one organization for each source that your firm interacts with the most for innovation activities. If not applicable, leave that row blank.

Please rate the degree to which the following statements describe your firm's relationship with your most important...

\begin{tabular}{|c|c|c|}
\hline & $\begin{array}{l}\text { Our business relationship with } \\
\text { this organization could be } \\
\text { described as “cooperative" } \\
\text { rather than an “arm's-length" } \\
\text { relationship. }\end{array}$ & $\begin{array}{l}\text { We expect to be interacting } \\
\text { with this organization far } \\
\text { into the future. }\end{array}$ \\
\hline Client or customer & $\begin{array}{l}\square \text { Strongly agree } \\
\square \text { Agree } \\
\square \text { Neither agree nor disagree } \\
\square \text { Disagree } \\
\square \text { Strongly disagree }\end{array}$ & $\begin{array}{l}\square \text { Strongly agree } \\
\square \text { Agree } \\
\square \text { Neither agree nor disagree } \\
\square \text { Disagree } \\
\square \text { Strongly disagree }\end{array}$ \\
\hline $\begin{array}{l}\text { Supplier of equipment, } \\
\text { materials, components, or } \\
\text { software }\end{array}$ & $\begin{array}{l}\square \text { Strongly agree } \\
\square \text { Agree } \\
\square \text { Neither agree nor disagree } \\
\square \text { Disagree } \\
\square \text { Strongly disagree }\end{array}$ & $\begin{array}{l}\square \text { Strongly agree } \\
\square \text { Agree } \\
\square \text { Neither agree nor disagree } \\
\square \text { Disagree } \\
\square \text { Strongly disagree }\end{array}$ \\
\hline Competitor & $\begin{array}{l}\square \text { Strongly agree } \\
\square \text { Agree } \\
\square \text { Neither agree nor disagree } \\
\square \text { Disagree } \\
\square \text { Strongly disagree }\end{array}$ & $\begin{array}{l}\square \text { Strongly agree } \\
\square \text { Agree } \\
\square \text { Neither agree nor disagree } \\
\square \text { Disagree } \\
\square \text { Strongly disagree }\end{array}$ \\
\hline Consultant & $\begin{array}{l}\square \text { Strongly agree } \\
\square \text { Agree } \\
\square \text { Neither agree nor disagree } \\
\square \text { Disagree } \\
\square \text { Strongly disagree }\end{array}$ & $\begin{array}{l}\square \text { Strongly agree } \\
\square \text { Agree } \\
\square \text { Neither agree nor disagree } \\
\square \text { Disagree } \\
\square \text { Strongly disagree }\end{array}$ \\
\hline $\begin{array}{l}\text { Commercial laboratory / } \\
\text { Research and Development } \\
\text { enterprise }\end{array}$ & $\begin{array}{l}\text { Strongly agree } \\
\square \text { Agree } \\
\square \text { Neither agree nor disagree } \\
\square \text { Disagree } \\
\square \text { Strongly disagree }\end{array}$ & $\begin{array}{l}\square \text { Strongly agree } \\
\square \text { Agree } \\
\square \text { Neither agree nor disagree } \\
\square \text { Disagree } \\
\square \text { Strongly disagree }\end{array}$ \\
\hline
\end{tabular}


Continuing on from the previous question, for each of the applicable information sources listed below, think of one organization for each source that your firm interacts with the most for innovation activities. If not applicable, leave that row blank.

Please rate the degree to which the following statements describe your firm's relationship with your most important...

\begin{tabular}{|c|c|c|}
\hline & $\begin{array}{l}\text { Our business relationship } \\
\text { with this organization could } \\
\text { be described as } \\
\text { “cooperative" rather than } \\
\text { an "arm's-length" } \\
\text { relationship. }\end{array}$ & $\begin{array}{l}\text { We expect to be interacting } \\
\text { with this organization far } \\
\text { into the future. }\end{array}$ \\
\hline $\begin{array}{l}\text { University or other higher } \\
\text { education institution }\end{array}$ & $\begin{array}{l}\square \text { Strongly agree } \\
\square \text { Agree } \\
\square \text { Neither agree nor disagree } \\
\square \text { Disagree } \\
\square \text { Strongly disagree }\end{array}$ & $\begin{array}{l}\square \text { Strongly agree } \\
\square \text { Agree } \\
\square \text { Neither agree nor disagree } \\
\square \text { Disagree } \\
\square \text { Strongly disagree }\end{array}$ \\
\hline $\begin{array}{l}\text { Government research } \\
\text { organization }\end{array}$ & $\begin{array}{l}\square \text { Strongly agree } \\
\square \text { Agree } \\
\square \text { Neither agree nor disagree } \\
\square \text { Disagree } \\
\square \text { Strongly disagree }\end{array}$ & $\begin{array}{l}\square \text { Strongly agree } \\
\square \text { Agree } \\
\square \text { Neither agree nor disagree } \\
\square \text { Disagree } \\
\square \text { Strongly disagree }\end{array}$ \\
\hline \begin{tabular}{l|} 
Other public sector \\
organization (such as \\
government office or small \\
business development center)
\end{tabular} & \begin{tabular}{|l|}
$\square$ Strongly agree \\
$\square$ Agree \\
$\square$ Neither agree nor disagree \\
$\square$ Disagree \\
$\square$ Strongly disagree
\end{tabular} & $\begin{array}{l}\square \text { Strongly agree } \\
\square \text { Agree } \\
\square \text { Neither agree nor disagree } \\
\square \text { Disagree } \\
\square \text { Strongly disagree }\end{array}$ \\
\hline Private research institution & $\begin{array}{l}\text { Strongly agree } \\
\square \text { Agree } \\
\square \text { Neither agree nor disagree } \\
\square \text { Disagree } \\
\square \text { Strongly disagree }\end{array}$ & $\begin{array}{l}\square \text { Strongly agree } \\
\square \text { Agree } \\
\square \text { Neither agree nor disagree } \\
\square \text { Disagree } \\
\square \text { Strongly disagree }\end{array}$ \\
\hline Trade association & $\begin{array}{l}\square \text { Strongly agree } \\
\square \text { Agree } \\
\square \text { Neither agree nor disagree } \\
\square \text { Disagree } \\
\square \text { Strongly disagree }\end{array}$ & $\begin{array}{l}\square \text { Strongly agree } \\
\square \text { Agree } \\
\square \text { Neither agree nor disagree } \\
\square \text { Disagree } \\
\square \text { Strongly disagree }\end{array}$ \\
\hline
\end{tabular}


21. Please identify the importance of the following objectives to your firm.

\begin{tabular}{|l|c|c|c|c|c|}
\cline { 2 - 6 } \multicolumn{1}{l|}{} & $\begin{array}{c}\text { Not } \\
\text { important } \\
\text { at all }\end{array}$ & $\begin{array}{c}\text { Not very } \\
\text { important }\end{array}$ & $\begin{array}{c}\text { Neither } \\
\text { important } \\
\text { nor } \\
\text { unimportant }\end{array}$ & $\begin{array}{c}\text { Somewhat } \\
\text { important }\end{array}$ & $\begin{array}{c}\text { Very } \\
\text { important }\end{array}$ \\
\hline $\begin{array}{l}\text { Replace outdated products / } \\
\text { services }\end{array}$ & 1 & 2 & 3 & 4 & 5 \\
\hline $\begin{array}{l}\text { Improve product / service } \\
\text { quality }\end{array}$ & 1 & 2 & 3 & 4 & 5 \\
\hline $\begin{array}{l}\text { Expand product / service } \\
\text { assortment }\end{array}$ & 1 & 2 & 3 & 4 & 5 \\
\hline $\begin{array}{l}\text { Enter new markets or increase } \\
\text { market share }\end{array}$ & 1 & 2 & 3 & 4 & 5 \\
\hline $\begin{array}{l}\text { Increase flexibility of product / } \\
\text { service delivery }\end{array}$ & 1 & 2 & 3 & 4 & 5 \\
\hline Reduce labor costs & 1 & 2 & 3 & 4 & 5 \\
\hline Reduce use of materials & 1 & 2 & 3 & 4 & 5 \\
\hline Reduce use of energy & 1 & 2 & 3 & 4 & 5 \\
\hline $\begin{array}{l}\text { Fulfill government regulation or } \\
\text { standards requirements }\end{array}$ & 1 & 2 & 3 & 4 & 5 \\
\hline Mitigate environmental damage & 1 & & & 4 & 5 \\
\hline
\end{tabular}


22. To what degree to you agree with the following statements about your firm?

\begin{tabular}{|l|c|c|c|c|c|}
\cline { 2 - 6 } \multicolumn{1}{l|}{} & $\begin{array}{c}\text { Strongly } \\
\text { Disagree }\end{array}$ & Disagree & $\begin{array}{c}\text { Neither Agree } \\
\text { nor Disagree }\end{array}$ & Agree & $\begin{array}{c}\text { Strongly } \\
\text { Agree }\end{array}$ \\
\hline $\begin{array}{l}\text { Rules and regulations occupy a } \\
\text { central place in the firm. }\end{array}$ & 1 & 2 & 3 & 4 & 5 \\
\hline $\begin{array}{l}\text { Written records are kept of } \\
\text { everyone's performance. }\end{array}$ & 1 & 2 & 3 & 4 & 5 \\
\hline $\begin{array}{l}\text { Employees are constantly } \\
\text { checked on for rule violations. }\end{array}$ & 1 & 2 & 3 & 4 & 5 \\
\hline $\begin{array}{l}\text { Written job descriptions are } \\
\text { formulated for positions at all } \\
\text { levels. }\end{array}$ & 1 & 2 & 3 & 4 & 5 \\
\hline $\begin{array}{l}\text { Whatever situation arises, } \\
\text { written procedures are available } \\
\text { for dealing with it. }\end{array}$ & 1 & 2 & 3 & 4 & 5 \\
\hline
\end{tabular}

23. To what degree to you agree with the following statements about your firm's industry?

\begin{tabular}{|l|c|c|c|c|c|}
\cline { 2 - 6 } \multicolumn{1}{l|}{} & $\begin{array}{c}\text { Strongly } \\
\text { Disagree }\end{array}$ & Disagree & $\begin{array}{c}\text { Neither Agree } \\
\text { nor Disagree }\end{array}$ & Agree & $\begin{array}{c}\text { Strongly } \\
\text { Agree }\end{array}$ \\
\hline $\begin{array}{l}\text { The technology in our industry } \\
\text { has been changing rapidly in the } \\
\text { past couple of years. }\end{array}$ & 1 & 2 & 3 & 4 & 5 \\
\hline $\begin{array}{l}\text { Research and Development } \\
\text { (R\&D) activity in our industry } \\
\text { has increased dramatically in the } \\
\text { past two to three years. }\end{array}$ & 1 & 2 & 3 & 4 & 5 \\
\hline $\begin{array}{l}\text { The product and service } \\
\text { obsolescence rate in our industry } \\
\text { is very high. }\end{array}$ & 1 & 2 & 3 & 4 & 5 \\
\hline
\end{tabular}




\begin{tabular}{|l|c|c|c|c|c|}
\cline { 2 - 5 } & $\begin{array}{c}\text { Completely } \\
\text { unsuccessful }\end{array}$ & $\begin{array}{c}\text { Somewhat } \\
\text { unsuccessful }\end{array}$ & $\begin{array}{c}\text { Neither } \\
\text { unsuccessful } \\
\text { nor successful }\end{array}$ & $\begin{array}{c}\text { Somewhat } \\
\text { successful }\end{array}$ & $\begin{array}{c}\text { Very } \\
\text { successful }\end{array}$ \\
\hline $\begin{array}{l}\text { How successful has your } \\
\text { firm been in developing } \\
\text { new products or services } \\
\text { in the past 3 years? }\end{array}$ & 1 & 2 & 3 & 4 & 5 \\
\hline
\end{tabular}

25. What percentage of current sales comes from new products or services introduced in the past 3 years? $\%$

An innovation project can be defined as a project intended to develop a new product or service idea, a new process technology, a new business model, or a new organizational form.

26. How many innovation projects are completed in a typical year in this firm? projects

27. Of the innovation projects planned for the past 3 years, how many projects were / are:

Completed:

In progress, but incomplete:

Not started:

Abandoned: projects

projects

projects

projects 
28. Please list your firm's 3 most important product or service introductions in the past 3 years.

(Please Note: If you do not wish to give the actual name, please provide a "code" name that you can identify with to answer a few short questions about each product / service introduction, such as "Product 1", “Service 2", etc.)

Product / Service 1:

How effective was this new product or service in doing the following?

\begin{tabular}{|l|c|c|c|c|c|}
\cline { 2 - 6 } & $\begin{array}{c}\text { Not effective } \\
\text { at all }\end{array}$ & $\begin{array}{c}\text { Not very } \\
\text { effective }\end{array}$ & $\begin{array}{c}\text { Neither effective } \\
\text { nor ineffective }\end{array}$ & $\begin{array}{c}\text { Somewhat } \\
\text { effective }\end{array}$ & $\begin{array}{c}\text { Very } \\
\text { effective }\end{array}$ \\
\hline $\begin{array}{l}\text { Reinforcing current } \\
\text { product or service lines. }\end{array}$ & 1 & 2 & 3 & 4 & 5 \\
\hline $\begin{array}{l}\text { Reinforcing expertise in } \\
\text { existing products or } \\
\text { services. }\end{array}$ & 1 & 2 & 3 & 4 & 5 \\
\hline $\begin{array}{l}\text { Reinforcing how the } \\
\text { firm currently } \\
\text { competes. }\end{array}$ & 1 & 2 & 3 & 4 & 5 \\
\hline
\end{tabular}

How effective was this new product or service in doing the following?

\begin{tabular}{|l|c|c|c|c|c|}
\cline { 2 - 6 } & $\begin{array}{c}\text { Not effective } \\
\text { at all }\end{array}$ & $\begin{array}{c}\text { Not very } \\
\text { effective }\end{array}$ & $\begin{array}{c}\text { Neither effective } \\
\text { nor ineffective }\end{array}$ & $\begin{array}{c}\text { Somewhat } \\
\text { effective }\end{array}$ & $\begin{array}{c}\text { Very } \\
\text { effective }\end{array}$ \\
\hline $\begin{array}{l}\text { Making present product } \\
\text { or service lines obsolete. }\end{array}$ & 1 & 2 & 3 & 4 & 5 \\
\hline $\begin{array}{l}\text { Fundamentally } \\
\text { changing current } \\
\text { products or services. }\end{array}$ & 1 & 2 & 3 & 4 & 5 \\
\hline $\begin{array}{l}\text { Making expertise in } \\
\text { existing products or } \\
\text { services obsolete. }\end{array}$ & 1 & 2 & 3 & 4 & 5 \\
\hline
\end{tabular}


Product / Service 2:

How effective was this new product or service in doing the following?

\begin{tabular}{|l|c|c|c|c|c|}
\cline { 2 - 6 } & $\begin{array}{c}\text { Not effective } \\
\text { at all }\end{array}$ & $\begin{array}{c}\text { Not very } \\
\text { effective }\end{array}$ & $\begin{array}{c}\text { Neither effective } \\
\text { nor ineffective }\end{array}$ & $\begin{array}{c}\text { Somewhat } \\
\text { effective }\end{array}$ & $\begin{array}{c}\text { Very } \\
\text { effective }\end{array}$ \\
\hline $\begin{array}{l}\text { Reinforcing current } \\
\text { product or service lines. }\end{array}$ & 1 & 2 & 3 & 4 & 5 \\
\hline $\begin{array}{l}\text { Reinforcing expertise in } \\
\text { existing products or } \\
\text { services. }\end{array}$ & 1 & 2 & 3 & 4 & 5 \\
\hline $\begin{array}{l}\text { Reinforcing how the } \\
\text { firm currently } \\
\text { competes. }\end{array}$ & 1 & 2 & 3 & 4 & 5 \\
\hline
\end{tabular}

How effective was this new product or service in doing the following?

\begin{tabular}{|l|c|c|c|c|c|}
\cline { 2 - 6 } & $\begin{array}{c}\text { Not effective } \\
\text { at all }\end{array}$ & $\begin{array}{c}\text { Not very } \\
\text { effective }\end{array}$ & $\begin{array}{c}\text { Neither effective } \\
\text { nor ineffective }\end{array}$ & $\begin{array}{c}\text { Somewhat } \\
\text { effective }\end{array}$ & $\begin{array}{c}\text { Very } \\
\text { effective }\end{array}$ \\
\hline $\begin{array}{l}\text { Making present product } \\
\text { or service lines obsolete. }\end{array}$ & 1 & 2 & 3 & 4 & 5 \\
\hline $\begin{array}{l}\text { Fundamentally } \\
\text { changing current } \\
\text { products or services. }\end{array}$ & 1 & 2 & 3 & 4 & 5 \\
\hline $\begin{array}{l}\text { Making expertise in } \\
\text { existing products or } \\
\text { services obsolete. }\end{array}$ & 1 & 2 & 3 & 4 & 5 \\
\hline
\end{tabular}


Product / Service 3:

How effective was this new product or service in doing the following?

\begin{tabular}{|l|c|c|c|c|c|}
\cline { 2 - 6 } & $\begin{array}{c}\text { Not effective } \\
\text { at all }\end{array}$ & $\begin{array}{c}\text { Not very } \\
\text { effective }\end{array}$ & $\begin{array}{c}\text { Neither effective } \\
\text { nor ineffective }\end{array}$ & $\begin{array}{c}\text { Somewhat } \\
\text { effective }\end{array}$ & $\begin{array}{c}\text { Very } \\
\text { effective }\end{array}$ \\
\hline $\begin{array}{l}\text { Reinforcing current } \\
\text { product or service lines. }\end{array}$ & 1 & 2 & 3 & 4 & 5 \\
\hline $\begin{array}{l}\text { Reinforcing expertise in } \\
\text { existing products or } \\
\text { services. }\end{array}$ & 1 & 2 & 3 & 4 & 5 \\
\hline $\begin{array}{l}\text { Reinforcing how the } \\
\text { firm currently } \\
\text { competes. }\end{array}$ & 1 & 2 & 3 & 4 & 5 \\
\hline
\end{tabular}

How effective was this new product or service in doing the following?

\begin{tabular}{|l|c|c|c|c|c|}
\cline { 2 - 6 } & $\begin{array}{c}\text { Not effective } \\
\text { at all }\end{array}$ & $\begin{array}{c}\text { Not very } \\
\text { effective }\end{array}$ & $\begin{array}{c}\text { Neither effective } \\
\text { nor ineffective }\end{array}$ & $\begin{array}{c}\text { Somewhat } \\
\text { effective }\end{array}$ & $\begin{array}{c}\text { Very } \\
\text { effective }\end{array}$ \\
\hline $\begin{array}{l}\text { Making present product } \\
\text { or service lines obsolete. }\end{array}$ & 1 & 2 & 3 & 4 & 5 \\
\hline $\begin{array}{l}\text { Fundamentally } \\
\text { changing current } \\
\text { products or services. }\end{array}$ & 1 & 2 & 3 & 4 & 5 \\
\hline $\begin{array}{l}\text { Making expertise in } \\
\text { existing products or } \\
\text { services obsolete. }\end{array}$ & 1 & 2 & 3 & 4 & 5 \\
\hline
\end{tabular}


29. During the past 3 years, has the firm delayed, prematurely stopped, abandoned and/or not started innovation projects due to any of the following reasons?

\begin{tabular}{|l|c|c|}
\cline { 2 - 3 } \multicolumn{1}{l|}{} & Yes & No \\
\hline Direct costs of innovation too high. & $\square$ & $\square$ \\
\hline Cost of finance hampering innovation. & $\square$ & $\square$ \\
\hline Excessive perceived economic risk. & $\square$ & $\square$ \\
\hline $\begin{array}{l}\text { Lack of customer responsiveness to new } \\
\text { products or services. }\end{array}$ & $\square$ & $\square$ \\
\hline Impact of regulations or standards. & $\square$ & $\square$ \\
\hline Availability of finance. & $\square$ & $\square$ \\
\hline Lack of information on markets. & $\square$ & $\square$ \\
\hline Lack of information on technology. & $\square$ & $\square$ \\
\hline Organizational rigidities within the firm. & $\square$ & $\square$ \\
\hline Lack of qualified personnel. & $\square$ & $\square$ \\
\hline $\begin{array}{l}\text { Other } \\
\text { Please specify: }\end{array}$ & $\square$ & $\square$ \\
\hline
\end{tabular}


30. Rate the extent you believe your firm has a competitive advantage or disadvantage in the following areas:

\begin{tabular}{|c|c|c|c|c|c|}
\hline & $\begin{array}{c}\text { Large } \\
\text { Disadvantage }\end{array}$ & $\begin{array}{c}\text { Some } \\
\text { Disadvantage }\end{array}$ & $\begin{array}{c}\text { Neither } \\
\text { Advantage nor } \\
\text { Disadvantage }\end{array}$ & $\begin{array}{c}\text { Some } \\
\text { Advantage }\end{array}$ & $\begin{array}{c}\text { Large } \\
\text { Advantage }\end{array}$ \\
\hline Dedicated employees & 1 & 2 & 3 & 4 & 5 \\
\hline Committed managers & 1 & 2 & 3 & 4 & 5 \\
\hline Owner-manager trust & 1 & 2 & 3 & 4 & 5 \\
\hline $\begin{array}{l}\text { Active board of directors } \\
\text { / advisers }\end{array}$ & 1 & 2 & 3 & 4 & 5 \\
\hline $\begin{array}{l}\text { Ratings for supplier } \\
\text { relations }\end{array}$ & 1 & 2 & 3 & 4 & 5 \\
\hline Loyal customers & 1 & 2 & 3 & 4 & 5 \\
\hline Reputation & 1 & 2 & 3 & 4 & 5 \\
\hline Banking relationships & 1 & 2 & 3 & 4 & 5 \\
\hline Efficient operations & 1 & 2 & 3 & 4 & 5 \\
\hline Marketing & 1 & 2 & 3 & 4 & 5 \\
\hline Developing innovations & 1 & 2 & 3 & 4 & 5 \\
\hline Products and/or services & 1 & 2 & 3 & 4 & 5 \\
\hline
\end{tabular}

31. What year was the firm established? 
32. How many employees does the firm have?

Full-time: employees

Part-time: employees

Contract: employees

33. Please select the industry that best describes your firm.

Agriculture, Mining

Construction

Finance, Insurance, Real Estate

$\square$ Government

$\square$ Health Care

Internet

Manufacturing

Retail, Wholesale

Services

Transportation

Communications, Utilities

Nonprofit

Other, please specify

34. Please provide the NAICS code for this firm, if known.

NAICS=North American Industry Classification System; NAICS codes are used by business and government to classify business establishments according to economic activity.

NAICS code: 
35. Please provide your firm's 2011 Return on Assets (ROA).

$($ ROA $=$ Net Profit after taxes $/$ Total Assets $)$

2011 ROA:

36. Please provide your firm's 2011 Return on Sales (ROS).

(ROS = Net Income (before interest and taxes) / Sales)

2011 ROS:

37. What percentage of your sales are international? $\%$

38. To the best of your knowledge, please select the box which you feel best estimates how YOUR FIRM currently compares to similar firms in your industry and region.

\begin{tabular}{|l|c|c|c|c|c|}
\cline { 2 - 6 } \multicolumn{1}{l|}{} & Lowest 20\% & Lower 20\% & Middle 20\% & Next 20\% & Top 20\% \\
\hline Return on Assets & 1 & 2 & 3 & 4 & 5 \\
\hline Return on Sales & 1 & 2 & 3 & 4 & 5 \\
\hline $\begin{array}{l}\text { Firm sales growth over } \\
\text { past 3 years }\end{array}$ & 1 & 2 & 3 & 4 & 5 \\
\hline $\begin{array}{l}\text { Overall firm } \\
\text { performance / success }\end{array}$ & 1 & 2 & 3 & 4 & 5 \\
\hline
\end{tabular}




\section{How long have you worked for this firm?}

$\square$ Less than 6 months

$\square 6$ months -1 year

$\square 2-4$ years

$5-7$ years

$8-10$ years

Greater than 10 years

40. Which of the following best describes your position within the firm?

$\square$ CEO / President / Managing Director

$\square \mathrm{COO} / \mathrm{CFO} / \mathrm{CTO} / \mathrm{CIO} / \mathrm{CMO}$

$\square$ Director / Partner / Vice President

$\square$ Senior Human Resources / Recruitment

$\square$ Other Human Resources / Recruitment

Manager / Executive

Consultant / Advisor

$\square$ Analyst / Specialist

Assistant / Administrator

$\square$ Other, please specify

\section{What is your gender?}

$\square$ Male

Female 
42. What is your current age?

43. What is the highest level of education you have completed?

$\square$ No formal education

Elementary school

$\square$ Middle school

High school

Some college

Bachelor's degree

Master’s degree

Ph.D.

44. How many years of full time work experience do you have?

Less than 1 year - up to 2 years

$3-5$ years

$\square 6-8$ years

$9-11$ years

$12-14$ years

15 or more years

\section{Thank you for participating in this survey!}




\section{CURRICULUM VITAE}

LAUREL F. OFSTEIN

February 2012

\section{EDUCATION}

2013

Ph.D. in Business Administration

University of Illinois at Chicago

Chicago, Illinois

2005

M.B.A. with Distinction

DePaul University, Kellstadt Graduate School of Business

Chicago, Illinois

Concentrations: Entrepreneurship and Marketing Management

1998

B.A. in Economics

Kalamazoo College

Kalamazoo, Michigan

\section{ACADEMIC HONORS AND AWARDS}

2010

Best Student Paper Award, Product Development and Management Association Research Forum

2008-2012

Liautaud Graduate Fellowship, University of Illinois at Chicago

\section{RESEARCH INTERESTS}

- Entrepreneurship in organizations and new venture teams

- Innovation and new product development

- Creativity in organizations and teams

- Family business management

\section{PUBLICATIONS AND RESEARCH}

\section{Books}

- Werhane, P., Posig, M., Gundry, L., Ofstein, L. and Powell, E. (2007). Women in Business: The Changing Face of Leadership, Portsmouth, NH: Greenwood.

\section{Book Chapters}

- Werhane, P., Posig, M., Gundry, L., Ofstein, L. and Powell, E. (2006). Women Leaders in Corporate America: A Study of Leadership Values and Methods in Karsten, M. (ed). Gender, Race, and Ethnicity in the Workplace [3 volumes]. New York: Greenwood-Praeger. 


\section{Cases}

- Ofstein, L. (2007). Case 4.1 JetBlue in Gundry, L.K. and Kickul J. Entrepreneurship Strategy: Changing Patterns in New Venture Creation, Growth, and Reinvention, (pp. 113118). Thousand Oaks, CA: Sage Publications, Inc.

- Ofstein, L. (2007). Case 9.1 Netflix in Gundry, L.K. and Kickul J. Entrepreneurship Strategy: Changing Patterns in New Venture Creation, Growth, and Reinvention, (pp. 310312). Thousand Oaks, CA: Sage Publications, Inc.

- Ofstein, L. (2007). A Sample Feasibility Study: Pet Élan in Katz, J.A. and Green, R. Entrepreneurial Small Business, (pp. 98-112). New York, NY: McGraw-Hill/Irwin.

\section{Edited Proceedings}

- Hills, G.E., Hultman, C., Monllor, J. and Ofstein, L.F., eds. (2009). Research at the Marketing/Entrepreneurship Interface. Proceedings of the 2008 Research Symposium on Marketing and Entrepreneurship.

\section{Conference Presentations}

- Ofstein, L., Shrader, R. (2013). Boundary Spanning in the Entrepreneurial Firm: Effects on Innovation and Firm Performance. Babson College Entrepreneurship Research Conference, June 2013, Écully, France (forthcoming).

- Ofstein, L.F., Shrader, R. and Renko, M. (2012). Boundary Spanning in the Entrepreneurial Firm: Effects on Innovation and Firm Performance. Global Research Symposium on Entrepreneurship and Marketing, August 2012, Chicago, IL.

- Ofstein, L.F., Shrader, R. and Renko, M. (2012). Boundary Spanning in the Entrepreneurial Firm: Effects on Innovation and Firm Performance. Academy of Management, August 2012, Boston, MA.

- Renko, M., Ofstein, L.F. and Hoobler, J.M. (2011). Entrepreneurial Passion and SelfEfficacy in the Development of Entrepreneurial Intent and Behaviors. Academy of Management, August 2011, San Antonio, TX.

- Ofstein, L. and Renko, M. (2011). The Nature of Experience: A Social Cognitive Perspective on the Drivers of Entrepreneurial Intentions. Babson College Entrepreneurship Research Conference, June 2011, Syracuse, NY.

- Ofstein, L.F. and Page, A.L. (2010). Building and Sustaining Creative Cross-Functional Teams: Influencing External Orientation in the New Product Development Process. Product Development and Management Association Research Forum, October 2010, Orlando, FL.

- Renko, M. and Ofstein, L.F. (2010). Entrepreneurial Passion, Self-Efficacy, and Entrepreneurial Intent. Academy of Management, August 2010, Montreal, QC Canada. 


\section{Working Papers}

- Renko, M., Ofstein, L.F. and Hoobler, J.M. Entrepreneurial Passion and Self-Efficacy in the Development of Entrepreneurial Intent and Behaviors. (Targeting submission to the Journal of Applied Psychology.)

- Ofstein, L., Shrader, R. and Renko, M. Innovating in the Entrepreneurial Firm: Boundary Spanning Activities and Absorptive Capacity. (Targeting submission to Journal of Business Venturing.)

\section{Research in Progress}

- Ofstein, L., Renko, M. and Bullough, A. Women’s Entrepreneurial Self-Efficacy and Opportunity Recognition Across Cultures. (Targeting submission to the International Journal of Gender and Entrepreneurship.)

\section{Trade/Professional Publications}

- Ofstein, L. (2011, March). 2010 Research Forum connects managers and academics. PDMA Visions Magazine, 25-29.

- Ofstein, L. (2011, March) 2010 Research Forum poster session. PDMA Visions Magazine, 28.

\section{Invited Presentations}

- Ofstein, L.F. (2012). Creativity and Leadership. DePaul University Student Leadership Institute, April 9, 2012, Chicago, IL.

- Ofstein, L.F. (2011). Innovation in Business. DePaul University Summer Business Institute, July 13, 2011, Chicago, IL.

- Ofstein, L.F. (2011). Innovate, Create and Thrive! Council on Botanical and Horticultural Libraries 2011 Annual Meeting, May 17, 2011, Chicago, IL.

- Ofstein, L.F. (2011). Creativity and Leadership. DePaul University Student Leadership Institute, April 28, 2011, Chicago, IL.

- Ofstein, L.F. (2011). Creating a Motivating Environment. DePaul University Student Leadership Institute, January 31, 2011, Chicago, IL.

- Ofstein, L.F. (2010). Creativity and Leadership. Harper College Leadership Challenge, October 25, 2010, Palatine, IL.

- Ofstein, L.F. (2009). Mastering Innovation. Havi Global Solutions, December 17, 2009, Chicago, IL.

- Ofstein, L.F. (2009). Sustaining and Growing Through Innovation: Creative and Practical Solutions for Special Libraries. Metropolitan Library System, November 6, 2009, Chicago, IL. 
- Ofstein, L.F. (2009). Creativity and Leadership. DePaul University Student Leadership Institute, October 5, 2009, Chicago, IL.

- Gundry, L. and Ofstein, L.F. (2008). Generating Creative Ideas for your Business. Federal Reserve Bank, May 5-6, 2008, Chicago, IL.

- Ofstein, L.F. (2008). Creative Collaboration: Setting the Course for the Future of Library Instruction. LOEX Conference, May 2, 2008, Chicago, IL.

\section{TEACHING INTERESTS}

- Entrepreneurship and New Venture Management

- Family Business Management

- Creativity in Business

- Strategic Management

\section{TEACHING EXPERIENCE}

\section{Graduate Level (MBA Program)}

Creativity in Business, MGT 573, DePaul University

Summer 2011, Winter 2011, Summer 2010, Spring 2008, Autumn 2007, Spring 2005

Corporate Ventures and Management, MGT 572, DePaul University

Winter 2008

\section{Undergraduate Level}

Entrepreneurship, MGMT 4140, Western Michigan University: Fall 2012

Small Business Management, MGMT 3140, Western Michigan University: Spring 2013

Strategic Business Solutions, BUS 4750, Western Michigan University: Fall 2012, Spring 2013

New Venture Formation, ENTR 454, University of Illinois at Chicago: Summer 2011, Fall 2010, Summer 2010

Family Business Management, ENTR 430, University of Illinois at Chicago: Spring 2012, Spring 2011

Creativity and Entrepreneurship, MGT 373, DePaul University: Summer 2009, Summer 2008, Summer 2007, Summer 2006

\section{PROFESSIONAL ACTIVITIES - AD HOC REVIEWER}

Academy of Management Conference Academy of Marketing Association Summer Educator's Conference Product Development and Management Association Research Forum 


\section{UNIVERSITY SERVICE}

Member of the New Faculty Advisory Board at Western Michigan University

Student representative to the Dean's Search Committee for the UIC College of Business Administration

\section{PROFESSIONAL EXPERIENCE}

2012-2013 Western Michigan University

Assistant Professor, Department of Management

Kalamazoo, Michigan

2005-2011 DePaul University

Adjunct Faculty, Department of Management

Chicago, Illinois

2005-2009 DePaul University

Assistant Director, The Center for Creativity and Innovation

Chicago, Illinois

2004-2005 DePaul University

Graduate Assistant, Department of Management

Chicago, Illinois

2004-2005 Tave Risk Management

Consulting Manager

Northbrook, Illinois

1998-2003 Accenture

Experienced Consultant

Chicago, Illinois 


\section{REFERENCES}

Adams, J. S. (1976). The structure and dynamics of behavior in organizational boundary roles. Handbook of industrial and organizational psychology (pp. 1175-1199) Rand McNally College Pub. Co.

Ahuja, G., and Katila, R. (2001). Technological acquisitions and the innovation performance of acquiring firms: A longitudinal study. Strategic Management Journal, 22(3), 197-220.

Ahuja, G., and Katila, R. (2004). Where do resources come from? the role of idiosyncratic situations. Strategic Management Journal, 25(8-9), 887-907.

Aiken, M., and Hage, J. (1968). Organizational interdependence and intra-organizational structure. American Sociological Review, 33(6), 912-930.

Alam, I. (2003). Commercial innovations from consulting engineering firms: An empirical exploration of a novel source of new product ideas. Journal of Product Innovation Management, 20(4), 300-313.

Aldrich, H. E., and Herker, D. (1977). Boundary spanning roles and organization structure. Academy of Management Review, 2(2), 217-230.

Ancona, D., Bresman, H., and Kaeufer, K. (2002). The comparative advantage of X-teams. MIT Sloan Management Review, 43(3), 33-39.

Andersson, L. M., and Bateman, T. S. (1997). Cynicism in the workplace: Some causes and effects. Journal of Organizational Behavior, 18(5), 449-469.

Argote, L. (1999). Organizational learning: Creating, retaining and transferring knowledge Springer. 
Armstrong, J. S., and Overton, T. (1977). Estimating nonresponse bias in mail surveys. Journal of Marketing Research, 14, 396-402.

Aulakh, P. S., and Gencturk, E. F. (2000). International principal-agent relationships: Control, governance and performance. Industrial Marketing Management, 29(6), 521-538.

Bagozzi, R. P., and Yi, Y. (1991). Multitrait-multimethod matrices in consumer research. Journal of Consumer Research, 17(4), 426-439.

Baron, R. M., and Kenny, D. A. (1986). The moderator-mediator variable distinction in social psychological research: Conceptual, strategic, and statistical considerations. Journal of Personality and Social Psychology, 51(6), 1173.

Birley, S. (1986). The role of networks in the entrepreneurial process. Journal of Business Venturing, 1(1), 107-117.

Bollen, K., and Lennox, R. (1991). Conventional wisdom on measurement: A structural equation perspective. Psychological Bulletin, 110(2), 305.

Branzei, O., and Vertinsky, I. (2006). Strategic pathways to product innovation capabilities in SMEs. Journal of Business Venturing, 21(1), 75-105.

Bresman, H. (2010). External learning activities and team performance: A multimethod field study. Organization Science, 21(1), 81-96.

Brodzinski, J. D., Scherer, R. F., and Wiebe, F. A. (1990). Boundary spanning activity: A function of the small business owner's decision style. Journal of Business and Entrepreneurship, 2(2), 1-12.

Brown, J. S., and Duguid, P. (2001). Knowledge and organization: A social-practice perspective. Organization Science, 12(2), 198-213. 
Burgelman, R. A., and Grove, A. S. (2007). Let chaos reign, then rein in chaos-repeatedly: Managing strategic dynamics for corporate longevity. Strategic Management Journal, 28(10), 965-979.

Burns, T., and Stalker, G. M. (1961). The management of innovation. London, UK: Tavistock.

Calantone, R. J., Cavusgil, S. T., and Zhao, Y. (2002). Learning orientation, firm innovation capability, and firm performance. Industrial Marketing Management, 31(6), 515-524.

Callister, R. R., and Wall Jr., J. A. (2001). Conflict across organizational boundaries: Managed care organizations versus health care providers. Journal of Applied Psychology, 86(4), 754.

Campbell, D. T., and Fiske, D. W. (1959). Convergent and discriminant validation by the multitrait-multimethod matrix. Psychological Bulletin, 56(2), 81.

Cassiman, B., and Veugelers, R. (2002). R\&D cooperation and spillovers: Some empirical evidence from Belgium. The American Economic Review, 92(4), 1169-1184.

Chesbrough, H. W. (2003). Open innovation: The new imperative for creating and profiting from technology. Harvard Business Press.

Chesbrough, H. W. (2006). The era of open innovation. Managing Innovation and Change, 127(3), 34-41.

Chrisman, J. J., McMullan, E., and Hall, J. (2005). The influence of guided preparation on the long-term performance of new ventures. Journal of Business Venturing, 20(6), 769-791.

Cohen, J., Cohen, P., West, S. G., and Aiken, L. S. (2003). Applied multiple regression: Correlation analysis for behavioral sciences (3rd ed.). Mahwah, NJ: L. Erlbaum Associates. Cohen, W. M., and Levinthal, D. A. (1989). Innovation and learning: The two faces of R \& D. The Economic Journal, 99(397), 569-596. 
Cohen, W. M., and Levinthal, D. A. (1990). Absorptive capacity: A new perspective on learning and innovation. Administrative Science Quarterly, 35(1), 128-152.

Cohen, W. M., and Levinthal, D. A. (1994). Fortune favors the prepared firm. Management Science, 40(2), 227-251.

Conant, J. S., Mokwa, M. P., and Varadarajan, P. R. (1990). Strategic types, distinctive marketing competencies and organizational performance: A multiple measures based study. Strategic Management Journal, 11(5), 365-383.

Cooper, A. C., Folta, T. B., and Woo, C. (1995). Entrepreneurial information search. Journal of Business Venturing, 10(2), 107-120.

Cooper, R. G., and Kleinschmidt, E. J. (1987). New products: What separates winners from losers? Journal of Product Innovation Management, 4(3), 169-184.

Cooper, R. G., and Kleinschmidt, E. J. (2000). New product performance: What distinguishes the star products. Australian Journal of Management, 25(1), 17-46.

Damanpour, F., Walker, R. M., and Avellaneda, C. N. (2009). Combinative effects of innovation types and organizational performance: A longitudinal study of service organizations. Journal of Management Studies, 46(4), 650-675.

Damanpour, F. (1991). Organizational innovation: A meta-analysis of effects of determinants and moderators. Academy of Management Journal, 34(3), 555-590.

de Brentani, U., and Reid, S. E. (2012). The fuzzy Front- End of discontinuous innovation: Insights for research and management. Journal of Product Innovation Management, 29(1), 70-87.

Dollinger, M. J. (1984). Environmental boundary spanning and information processing effects on organizational performance. Academy of Management Journal, 27(2), 351-368. 
Dougherty, D., and Hardy, C. (1996). Sustained product innovation in large, mature organizations: Overcoming innovation-to-organization problems. The Academy of Management Journal, 39(5), 1120-1153.

Dubini, P., and Aldrich, H. E. (1991). Personal and extended networks are central to the entrepreneurial process. Journal of Business Venturing, 6(5), 305-313.

Ensley, M. D., Pearson, A. W., and Amason, A. C. (2002). Understanding the dynamics of new venture top management teams: Cohesion, conflict, and new venture performance. Journal of Business Venturing, 17(4), 365-386.

Fang, E. (2008). Customer participation and the trade-off between new product innovativeness and speed to market. Journal of Marketing, 72(4), 90-104.

Fiol, C. M., and Lyles, M. A. (1985). Organizational learning. Academy of Management Review, 10(4), 803-813.

Freeze, R., and Raschke, R. L. (2007). An assessment of formative and reflective constructs in is research. Unpublished manuscript.

Gartner, W. B. (1988). "Who is an entrepreneur?" is the wrong question. American Journal of Small Business, 12(4), 11-32.

Garud, R., and Ven de Ven, A. H. (1992). An empirical evaluation of the internal corporate venturing process. Strategic Management Journal, 13(S1), 93-109.

Garud, R., and Nayyar, P. R. (1994). Transformative capacity: Continual structuring by intertemporal technology transfer. Strategic Management Journal, 15(5), 365-385.

Gassmann, O., Enkel, E., and Chesbrough, H. (2010). The future of open innovation. $R \& D$ Management, 40(3), 213-221. 
Golden, T. D., and Veiga, J. F. (2005). Spanning boundaries and borders: Toward understanding the cultural dimensions of team boundary spanning. Journal of Managerial Issues, 17(2), 178-197.

Grant, R. M. (1996). Toward a knowledge-based theory of the firm. Strategic Management Journal, 17, 109-122.

Greene, C. N., and Organ, D. W. (1973). An evaluation of causal models linking the received role with job satisfaction. Administrative Science Quarterly, 18(1), 95-103.

Grimpe, C., and Sofka, W. (2009). Search patterns and absorptive capacity: Low- and hightechnology sectors in European countries. Research Policy, 38(3), 495-506.

Hair Jr, J. F., Black, W. C., Babin, B. J., and Anderson, R. E. (2009). Multivariate data analysis (7th ed.) Prentice Hall.

He, Z. L., and Wong, P. K. (2004). Exploration vs. exploitation: An empirical test of the ambidexterity hypothesis. Organization Science, 15(4), 481-494.

Henderson, R., and Cockburn, I. (1994). Measuring competence? exploring firm effects in pharmaceutical research. Strategic Management Journal, 15(S1), 63-84.

Hollenstein, H. (1996). A composite indicator of a firm's innovativeness: An empirical analysis based on survey data for Swiss manufacturing. Research Policy, 25(4), 633-645.

Hoy, F. (2008). Organizational learning at the marketing/entrepreneurship interface. Journal of Small Business Management, 46(1), 152-158.

Huber, G. P. (1991). Organizational learning: The contributing processes and the literatures. Organization Science, 2(1), 88-115. 
Hult, G. T. M. (2011). Toward a theory of the boundary-spanning marketing organization and insights from 31 organization theories. Journal of the Academy of Marketing Science, 39(4), 509-536.

Hurt, H. T., Joseph, K., and Cook, C. D. (1977). Scales for the measurement of innovativeness. Human Communication Research, 4(1), 58-65.

Hurt, H. T., and Teigen, C. W. (1977). The development of a measure of perceived organizational innovativeness. Communication Yearbook, 1(1), 377-385.

Jaccard, J., Wan, C. K., and Turrisi, R. (1990). The detection and interpretation of interaction effects between continuous variables in multiple regression. Multivariate Behavioral Research, 25(4), 467-478.

Jansen, J. J. P., Van Den Bosch, F. A. J., and Volberda, H. W. (2005). Managing potential and realized absorptive capacity: How do organizational antecedents matter? Academy of Management Journal, 48(6), 999-1015.

Jonsson, K., Holmstrom, J., and Lyytinen, K. (2009). Turn to the material: Remote diagnostics systems and new forms of boundary-spanning. Information and Organization, 19(4), 233252.

Katila, R. (2002). New product search over time: Past ideas in their prime? Academy of Management Journal, 45(5), 995-1010.

Katila, R., and Ahuja, G. (2002). Something old, something new: A longitudinal study of search behavior and new product introduction. Academy of Management Journal, 45(6), 11831194.

Katz, D., and Kahn, R. L. (1978). The social psychology of organizations. New York: Wiley \& Sons. 
Keller, R. T., and Holland, W. E. (1975). Boundary-spanning roles in a research and development organization: An empirical investigation. Academy of Management Journal, 18(2), 388-393.

Kerlinger, F. N. (1986). Foundations of behavioral research (3rd ed.). New York: Holt, Rinehart and Winston.

Kirchhoff, B. A. (1994). Entrepreneurship and dynamic capitalism: The economics of business firm formation and growth. Westport, Conn.: Praeger.

Klevorick, A. K., Levin, R. C., Nelson, R. R., and Winter, S. G. (1995). On the sources and significance of interindustry differences in technological opportunities. Research Policy, 24(2), 185-205.

Kostopoulos, K., Papalexandris, A., Papachroni, M., and Ioannou, G. (2011). Absorptive capacity, innovation, and financial performance. Journal of Business Research, 64(12), 1335-1343.

Koza, M. P., and Lewin, A. Y. (1998). The co-evolution of strategic alliances. Organization Science, 9(3), 255-264.

Lane, P. J., Koka, B. R., and Pathak, S. (2006). The reification of absorptive capacity: A critical review and rejuvenation of the construct. Academy of Management Review, 31(4), 833-863.

Lane, P. J., and Lubatkin, M. (1998). Relative absorptive capacity and interorganizational learning. Strategic Management Journal, 19(5), 461-477.

Larson, A. (1991). Partner networks: Leveraging external ties to improve entrepreneurial performance. Journal of Business Venturing, 6(3), 173-188. 
Laursen, K., and Salter, A. (2006). Open for innovation: The role of openness in explaining innovation performance among UK manufacturing firms. Strategic Management Journal, 27(2), 131-150.

Leifer, R., and Delbecq, A. (1978). Organizational/environmental interchange: A model of boundary spanning activity. Academy of Management Review, 3(1), 40-50.

Leifer, R., and Huber, G. P. (1977). Relations among perceived environmental uncertainty, organization structure, and boundary-spanning behavior. Administrative Science Quarterly, 22(2), 235-247.

Leiponen, A., and Helfat, C. E. (2010). Innovation objectives, knowledge sources, and the benefits of breadth. Strategic Management Journal, 31(2), 224-236.

Leonard-Barton, D. (1992). Core capabilities and core rigidities: A paradox in managing new product development. Strategic Management Journal, 13(S1), 111-125.

Levin, R. C., Klevorick, A. K., Nelson, R. R., Winter, S. G., Gilbert, R., and Griliches, Z. (1987). Appropriating the returns from industrial research and development. Brookings Papers on Economic Economy, 1987(3), 783-831.

Li, T., and Calantone, R. J. (1998). The impact of market knowledge competence on new product advantage: Conceptualization and empirical examination. Journal of Marketing, 62(4), 1329.

Lichtenthaler, U. (2009). Absorptive capacity, environmental turbulence, and the complementarity of organizational learning processes. Academy of Management Journal, 52(4), 822-846.

Lysonski, S. (1985). A boundary theory investigation of the product manager's role. Journal of Marketing, 49(1), 26-40. 
Manu, F. A. (1992). Innovation orientation, environment and performance: A comparison of US and European markets. Journal of International Business Studies, 23(2), 333-359.

March, J. G. (1991). Exploration and exploitation in organizational learning. Organization Science, 2(1), 71-87.

Meyer, A. D. (1982). Adapting to environmental jolts. Administrative Science Quarterly, 27(4), 515-537.

Miller, D. (1983). The correlates of entrepreneurship in three types of firms. Management Science, 29(7), 770-791.

Mol, M. J., and Birkinshaw, J. (2009). The sources of management innovation: When firms introduce new management practices. Journal of Business Research, 62(12), 1269-1280.

Mone, M. A., McKinley, W., and Barker, V. L. (1998). Organizational decline and innovation: A contingency framework. Academy of Management Review, 23(1), 115-132.

Morgan, R. E., and Berthon, P. (2008). Market orientation, generative learning, innovation strategy and business performance Inter- Relationships in bioscience firms. Journal of Management Studies, 45(8), 1329-1353.

Mowery, D. C., Oxley, J. E., and Silverman, B. S. (1996). Strategic alliances and interfirm knowledge transfer. Strategic Management Journal, 17(Winter), 77-91.

Murphy, G. B., Trailer, J. W., and Hill, R. C. (1996). Measuring performance in entrepreneurship research. Journal of Business Research, 36(1), 15-23.

Myers, J. H., and Mullet, G. M. (2003). Managerial applications of multivariate analysis in marketing. Chicago, IL: American Marketing Association.

Nooteboom, B. (1994). Innovation and diffusion in small firms: Theory and evidence. Small Business Economics, 6(5), 327-347. 
Nunnally, J. C. (1978). Psychometric theory (2nd ed.). New York: McGraw-Hill.

Organ, D. W., and Greene, C. N. (1981). The effects of formalization on professional involvement: A compensatory process approach. Administrative Science Quarterly, 26(2), 237-252.

Pearce II, J. A., Robbins, D. K., and Robinson Jr., R. B. (1987). The impact of grand strategy and planning formality on financial performance. Strategic Management Journal, 8(2), 125-134.

Pennings, J. M., and Harianto, F. (1992). The diffusion of technological innovation in the commercial banking industry. Strategic Management Journal, 13(1), 29-46.

Pérez- Nordtvedt, L., Kedia, B. L., Datta, D. K., and Rasheed, A. A. (2008). Effectiveness and efficiency of Cross- Border knowledge transfer: An empirical examination. Journal of Management Studies, 45(4), 714-744.

Peter, J. P. (1981). Construct validity: A review of basic issues and marketing practices. Journal of Marketing Research, 18(2), 133-145.

Podsakoff, P. M., MacKenzie, S. B., Lee, J., and Podsakoff, N. P. (2003). Common method biases in behavioral research: A critical review of the literature and recommended remedies. Journal of Applied Psychology, 88(5), 879-903.

Rao, R. D., and Argote, L. (2006). Organizational learning and forgetting: The effects of turnover and structure. European Management Review, 3(2), 77-85.

Ravasi, D., and Turati, C. (2005). Exploring entrepreneurial learning: A comparative study of technology development projects. Journal of Business Venturing, 20(1), 137-164.

Rosenbusch, N., Brinckmann, J., and Bausch, A. (2011). Is innovation always beneficial? A meta-analysis of the relationship between innovation and performance in SMEs. Journal of Business Venturing, 26, 441-457. 
Rosenkopf, L., and Nerkar, A. (2001). Beyond local search: Boundary spanning, exploration, and impact in the optical disk industry. Strategic Management Journal, 22(4), 287-306.

Rothaermel, F. T. (2001). Incumbent's advantage through exploiting complementary assets via interfirm cooperation. Strategic Management Journal, 22(6- 7), 687-699.

Rothaermel, F. T., and Alexandre, M. T. (2009). Ambidexterity in technology sourcing: The moderating role of absorptive capacity. Organization Science, 20(4), 759-780.

Schumpeter, J. (1934). The theory of economic development. Cambridge, MA: Harvard University Press.

Schumpeter, J. (1976). Capitalism, socialism and democracy (3rd ed.). New York: Harper \& Row.

Scott, J. (1991). Social network analysis: A handbook. London: Sage.

Scott, W. R. (1998). Organizations: Rational, natural, and open systems (4th ed.). Upper Saddle River, New Jersey: Prentice Hall.

Shane, S., and Venkataraman, S. (2000). The promise of entrepreneurship as a field of research. Academy of Management Review, 25(1), 217-226.

Sidhu, J. S., Commandeur, H. R., and Volberda, H. W. (2007). The multifaceted nature of exploration and exploitation: Value of supply, demand, and spatial search for innovation. Organization Science, 18(1), 20-38.

Small giants community. (2013). Retrieved from http://www.smallgiants.org.

Smith, K. G., Collins, C. J., and Clark, K. D. (2005). Existing knowledge, knowledge creation capability, and the rate of new product introduction in high-technology firms. Academy of Management Journal, 48(2), 346-357.

Snow, C. C. (2007). Innovation. Strategic Entrepreneurship Journal, 1(1-2), 101-102. 
Sturdy, A., and Wright, C. (2011). The active client: The boundary-spanning roles of internal consultants as gatekeepers, brokers and partners of their external counterparts. Management Learning, 42(5), 485-503.

Subramaniam, M., and Youndt, M. A. (2005). The influence of intellectual capital on the types of innovative capabilities. Academy of Management Journal, 48(3), 450-463.

Szulanski, G. (1996). Exploring internal stickiness: Impediments to the transfer of best practice within the firm. Strategic Management Journal, 17(Winter), 27-43.

Todorova, G., and Durisin, B. (2007). Absorptive capacity: Valuing a reconceptualization. Academy of Management Review, 32(3), 774-786.

Tsai, W. (2001). Knowledge transfer in intraorganizational networks: Effects of network position and absorptive capacity on business unit innovation and performance. Academy of Management Journal, 44(5), 996-1004.

Tushman, M. L. (1977). Special boundary roles in the innovation process. Administrative Science Quarterly, 22(4), 587-605.

Tushman, M. L., and Scanlan, T. J. (1981). Characteristics and external orientations of boundary spanning individuals. Academy of Management Journal, 24(1), 83-98.

Utterback, J. M. (1971). The process of technological innovation within the firm. Academy of Management Journal, 14(1), 75-88.

Vanhaverbeke, W., Beerkens, B., Duysters, G., and Gilsing, V. A. (2004). Explorative and exploitative learning strategies in technology-based alliance networks. Academy of Management, Best Conference Paper. TIM. 
Von Hippel, E. (1988). The sources of innovation. University of Illinois at Urbana-Champaign's Academy for Entrepreneurial Leadership Historical Research Reference in Entrepreneurship.

Von Hippel, E., and Tyre, M. J. (1995). How learning by doing is done: Problem identification in novel process equipment. Research Policy, 24(1), 1-12.

Wasserman, S., and Faust, K. (1994). Social network analysis: Methods and applications. Cambridge: Cambridge University Press.

Zahra, S. A. (2008). The virtuous cycle of discovery and creation of entrepreneurial opportunities. Strategic Entrepreneurship Journal, 2(3), 243-257.

Zahra, S. A. (2012). Organizational learning and entrepreneurship in family firms: Exploring the moderating effect of ownership and cohesion. Small Business Economics, 38(1), 51-65.

Zahra, S. A., Ireland, R. D., and Hitt, M. A. (2000). International expansion by new venture firms: International diversity, mode of market entry, technological learning, and performance. Academy of Management Journal, 43(5), 925-950.

Zahra, S. A., and George, G. (2002). Absorptive capacity: A review, reconceptualization, and extension. Academy of Management Review, 27(2), 185-203. 